
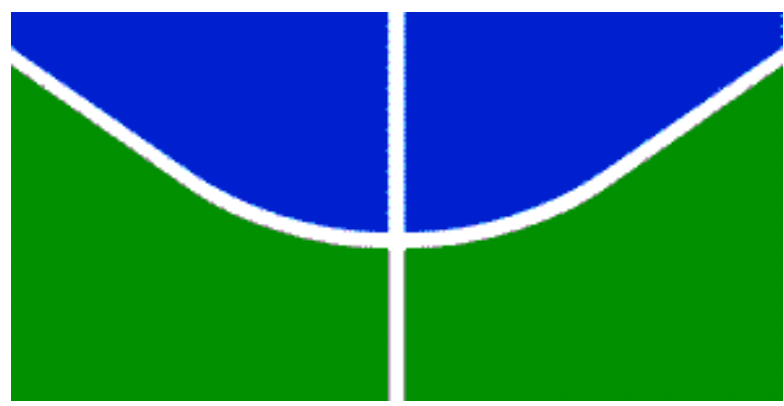

UNIVERSIDADE DE BRASÍLIA

Instituto de Letras

Programa de Pós-Graduação em Literatura

Damiana Pereira de Paula

\title{
O Processo Criativo e a Personalidade Criadora: \\ Um Estudo da Poética de Anaïs Nin no Poema em Prosa \\ A Casa do Incesto
}

Brasília-DF 
Damiana Pereira de Paula

\section{O Processo Criativo e a Personalidade Criadora: \\ Um Estudo da Poética de Anaïs Nin no Poema em Prosa \\ A casa do incesto}

Tese apresentada à Comissão Examinadora do Programa de Pós-graduação em Literatura do Departamento de Teoria Literária e Literaturas da Universidade de Brasília como parte dos requisitos para obtenção do título de Doutor, desenvolvida sob a orientação do Prof. Dr. Henryk Siewierski 
BANCA EXAMINADORA

\begin{tabular}{c}
\hline Prof. Dr. Henryk Siewierski \\
PÓSLIT/TEL/UnB \\
Presidente
\end{tabular}

\begin{tabular}{|c|}
\hline $\begin{array}{c}\text { Profa. Dra. Alessandra Matias Querido } \\
\text { Universidade Católica de Brasília } \\
\text { Examinadora }\end{array}$ \\
\hline $\begin{array}{l}\text { Profa. Dra. Ana Helena Rossi } \\
\text { LET/UnB } \\
\text { Examinadora }\end{array}$ \\
\hline
\end{tabular}

Prof. Dr. Eclair Antonio Almeida Filho

LET/UnB

Examinador
Prof. Dr. Wilton Barroso Filho PÓSLIT/TEL/UnB
Examinador
Prof. Dr. Paweł Hejmanowski
TEL/UnB
Suplente




\section{AGRADECIMENTOS}

Ao meu orientador, Prof. Dr. Henryk Siewierski, pela constante generosidade na troca de ideias e por inspirar uma forma de conhecimento situado entre a serenidade e o rigor. Aos meus pais, pelo incentivo aos estudos, pelo apoio financeiro e pelo carinho.

Aos meus irmãos Cristiano e Aline, à vovó Terezinha e Carlos Henrique, pelos laços profundos que nos une.

Aos professores Elga Pérez Labore e Eclair Antonio Almeida Filho, que participaram da banca de qualificação e que muito contribuíram com sugestões para elaboração da tese.

À amiga Adriana Félix, por ter me auxiliado a solucionar uma questão de tradução do poema A casa do incesto e pelo carinho.

À amiga Mariana Carpanezzi, pela revisão cuidadosa da tese, pelo carinho e amizade.

À amiga Denise Costa, pela leitura da tese e pela amizade.

À amiga Simone Rodrigues do Amaral, por ter me recomendado o livro A dupla chama: amor e erotismo, de Octavio Paz e pela amizade.

A Paweł Hejmanowski, por ter me introduzido à obra de Anaïs Nin, pela leitura cuidadosa da tese, pelas sugestões e, acima de tudo, pelo companheirismo de toda uma vida. 
A seguinte pesquisa de doutorado foi realizada com o apoio financeiro da CAPES. 
Em sigilo trabalhavas

Isto era preciso -

Acolher o extraviado,

Absorver o dissolvido.

Não de um modo pesaroso,

Mas com a leve distração

De quem entra no insondável

E nele sobrevive

Descentrado, possuído.

Mariana Ianelli, Almádena

O poema não é uma forma literária, mas o ponto de encontro entre a poesia e o homem.

Octavio Paz, O arco e a lira

So it is: we all have our roots in earth. And it is our roots that now need a little attention, need the hard soil eased away from them, and softened so that a little fresh air can come to them, and they can breathe. For by pretending to have no roots, we have trodden the earth so hard over them that they are starving and stifling below the soil. We have roots, and our roots are in the sensual, instinctive and intuitive body, and it is here we need fresh air of open consciousness.

\section{H. Lawrence, Introduction to the Unexpurgated Edition of Pansies}

Either get ready

For elimination

Or else your heart

Must have the courage

For the changing of the guards.

\section{Bob Dylan, The Changing of the Guards}

Writing and reading is itself an initiation as special as the totem-dance of the Aranda, and just as the Aranda learns to read his own parts in the parts of the landscape about him, so that the body of the world becomes one with his own consciousness, so we learn to find our life in literature, and, in turn literature itself is valued as it seems true to life.

Robert Duncan, The H. D. Book 


\section{SUMÁRIO}

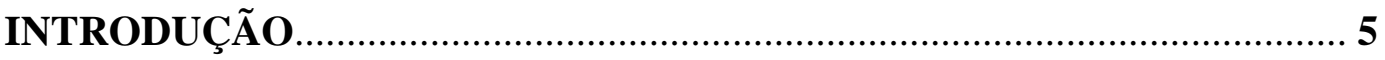

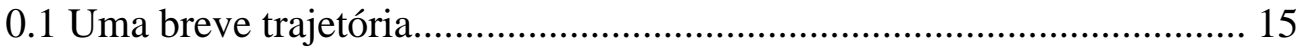

0.2 Escrita luminosa e sedutora................................................................... 18

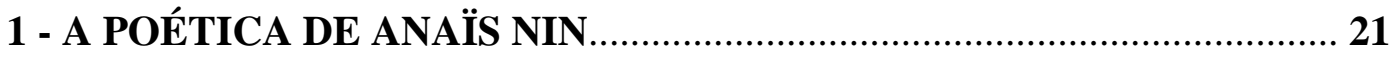

1.1 Diário versus ficção................................................................................ 47

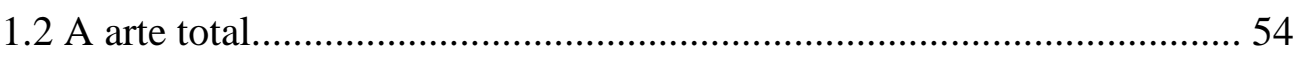

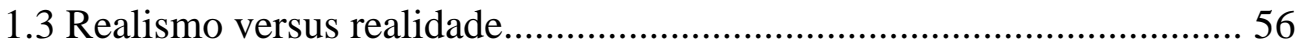

2 - A CASA DO INCESTO E SUA GÊNESE ……………………………….... 60

2.1 Influências do movimento Surrealista....................................................... 60

2.2 A relação entre o diário Incest e $A$ casa do incesto.................................. 70

2.3 A origem dos personagens de $A$ casa do incesto....................................... 81

3 - UMA POSSÍVEL LEITURA DE A CASA DO INCESTO …..................... 97

4 - COMENTÁRIO SOBRE A TRADUÇÃO DE A CASA DO INCESTO..105

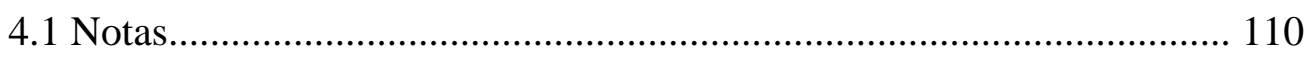

5 - TRADUÇÃO DE A CASA DO INCESTO …………………………….......116

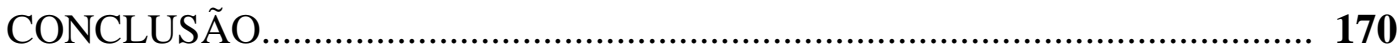

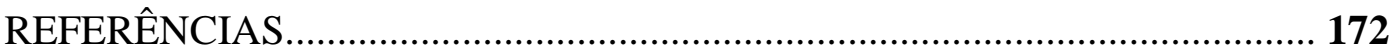




\section{RESUMO}

O universo ficcional da escritora Anaïs Nin se destaca no cenário literário pela sua poeticidade e lirismo bem como pela sua preocupação em desvendar o mundo da subjetividade humana por meio da criação de imagens e símbolos. Em sua vasta obra, a autora se dedicou à escrita de diários, romances experimentais, poema em prosa, contos, contos eróticos, cartas, crítica literária e ensaios. O objetivo da presente tese é analisar o tema da criação artística e da personalidade criadora no poema em prosa $A$ casa do incesto. A abordagem estética do poema está centrada em dois aspectos: primeiramente realiza um estudo de suas influências - fortemente marcadas pelo movimento Surrealista, pelas ideias psicanalíticas, pela poesia Simbolista, sobretudo Rimbaud - e, em um segundo momento, explora a relação que o poema mantém com a escrita dos diários.

Palavras-Chaves: Criação Artística, Personalidade Criadora, Diário, Poesia em Prosa, Literatura e Psicanálise. 


\begin{abstract}
The fictional universe created by Anaïs Nin is celebrated for its highly poetical and lyrical form, abounding with images and symbols through which the world of human subjectivity is revealed. Nin was a prolific writer and throughout her life published diaries, experimental novels, a prose poem, short-stories, erotica, letters, literary criticism and essays. The present thesis aims at analyzing the theme of artistic creation and the creative personality in the prose poem House of Incest. The aesthetic approach of the poem is focused on two different aspects: Firstly, it explores the influences of the Surrealist movement, psychoanalysis and Symbolism - especially Rimbaud. Secondly, it investigates the connections between the poem and the diaries.
\end{abstract}

Key words: Artistic Creation, Creative Personality, Diary, Prose Poem, Literature and Psychoanalysis. 


\section{INTRODUÇÃO}

O conjunto da obra da escritora Anaïs Nin é único no universo literário. Isso se deve ao seu caráter experimental, originalidade e monumentalidade. Poucos foram os escritores que se dedicaram uma vida inteira a escrever e a refletir sobre o processo criativo e a personalidade criadora. Este é o tema central da obra de Nin e o tema de estudo da presente tese.

A escrita de Nin dialoga incessantemente com outros campos das artes, principalmente com a música e as artes plásticas. Escrita poética e sinfônica que pretende ir muito além dos limites do que convencionalmente se entende por literatura e gêneros literários. "Ninguém vai entender meus versos, se quiser interpretá-los como performances literárias", 1 disse o poeta Walt Whitman a respeito de sua própria poesia. O mesmo pode-se afirmar sobre a poética de Nin. Penetrar em seu universo é encontrarse subitamente em um labirinto, um "edifício sem dimensão", um salão de espelhos, “cidades suspensas no ar" que velam e desvelam o ser. Não é uma obra para desavisados. Impossível sair incólume dessa travessia.

Nin afirmava que o universo ficcional que havia criado era tão vasto que ela se perdia dentro dele. Para a autora, o mesmo iria acontecer com seus leitores e que estes se sentiriam imensamente gratos por isso. A leitura de sua obra é um convite à perdição, a percorrer todo céu e inferno contido nesta palavra. Aqui, céu e inferno não são realidades isoladas: quanto mais vertiginosa a queda mais intensa é a ascensão. A voz de Nin é a mesma voz de Breton que grita em Amor louco: "Nunca houve qualquer fruto proibido. Só a tentação é divina". ${ }^{2}$ Em Nin, tanto a tentação quanto a perdição são de natureza divina, pois estão intrinsecamente associadas com o despertar da capacidade visionária poética.

É verdade que, para cada obra, existe um tipo de leitor ideal em que certas qualidades intelectuais e espirituais são exigidas. O leitor de Nin é constantemente conduzido a um confronto com seus limites, principalmente de ordem moral. Por isso, naturezas rígidas não conseguem penetrar em seu universo. Aqueles que trazem consigo

\footnotetext{
${ }^{1}$ Citado por Leminski em Anseios crípticos 2, p. 63.

${ }^{2}$ Citado por Willer em "Magia, poesia e realidade: o acaso objetivo em André Breton". In: Guinsburg e Leiner. $O$ Surrealismo, p. 347.
} 
uma abertura espiritual para o novo e uma sede de conhecer novas realidades irão compreender a maneira pela qual Nin se conecta com a vida e a arte. Para quem aceitar o desafio, uma fabulosa jornada se inicia e, ao fim dessa viagem, é possível entrever a vista vasta da existência que sua obra apresenta.

Nin acreditava que poucos seriam aqueles a ter contato realmente profundo com sua escrita. E, para esse pequeno grupo seleto, sua literatura teria um impacto avassalador e explosivo. No entanto, o círculo de leitores e admiradores de Nin continua a crescer, principalmente na Europa e Estados Unidos. Trinta e oito anos após sua morte, sua obra nunca foi tão lida e apreciada. Um dos motivos de tal façanha é que volumes inéditos do diário original continuam sendo publicados e, dessa forma, despertando o interesse de novas gerações.

No Brasil, a obra de Nin é pouco conhecida. Apenas alguns de seus livros foram traduzidos. Sua inserção no meio acadêmico é quase inexistente. No Banco de Teses da CAPES, consta apenas uma dissertação de mestrado em História, intitulada A Arte da Memória: uma análise da escrita íntima de Anaïs Nin, de Raquel Thomaz de Andrade, defendida no Departamento de História da Universidade Federal de Campina Grande, no ano de 2010. Levando-se em conta esta informação, um dos objetivos principais desta tese de doutorado seria de introduzir sua obra à comunidade acadêmica e tentar suprir a lacuna de pesquisas relacionadas à sua arte poética.

O objeto de estudo desta tese é o poema em prosa A casa do incesto, primeiro livro de ficção de Nin, publicado na França, em 1934. Esta escolha foi feita por dois motivos: primeiramente, ao pesquisar a fortuna crítica de Nin, para minha surpresa, pude perceber que poucos estudos haviam sido feitos sobre esta obra. Segundo, por ser este poema sua obra mais inovadora e experimental e por conter todos os temas que Nin viria a desenvolver mais tarde em outros livros de ficção. "Tudo que sei está contido neste livro escrito sem testemunha, edifício sem dimensão, cidade suspensa no céu," diz Nin na primeira página de A casa do incesto. Outro aspecto relevante na abordagem do poema seria de dar continuidade à tese de Anna Balakian de que Nin deve ser lida como uma poeta inserida na tradição literária Simbolista. ${ }^{3}$

\footnotetext{
${ }^{3}$ Balakian, Anna. “Anaïs Nin, the Poet”. In: Nalbantian, Anaïs Nin: Literary Perspectives, p. 63.
} 
Junto ao estudo crítico, apresento nesta tese uma tradução de A casa do incesto. Durante minhas pesquisas, constatei que duas traduções do poema já haviam sido realizadas para a língua portuguesa: a primeira, uma edição portuguesa, publicada pela editora Assírio \& Alvim, em 1984; a segunda, uma edição brasileira, publicada pela editora Rosa dos Ventos, em 1990. Não é a minha intenção fazer uma crítica dessas traduções ou apontar equívocos. Entretanto, após analisá-las cuidadosamente, percebi que o vigor poético da escrita de Nin, de um modo geral, havia se perdido. A certeza de que seria possível explorar, de maneira mais profunda, o manancial poético da língua portuguesa para preservar a força e o frescor das imagens criadas por Nin foi o que me motivou a realizar uma nova tradução. E, aqui, o conceito de tradução como transcriação, desenvolvido por Haroldo de Campos, me serviu de fundamentação teórica.

A presente tese é composta por quatro capítulos: o primeiro capítulo, "A poética de Anaïs Nin”, investiga as principais ideias que nortearam sua criação poética, além de discutir a relação entre a escrita do diário e da ficção; o segundo capítulo, " $A$ casa do incesto e sua gênese", destina-se à análise de algumas ideias do movimento surrealista e a influência do diário Incest na criação do poema e de seus personagens; o terceiro capítulo, "Uma possível leitura de A casa do incesto", interpreta a simbologia do poema. O quarto capítulo, "Comentário sobre a tradução de A casa do incesto", analisa algumas ideias que nortearam a tradução do poema e discute alguns problemas e soluções encontradas no processo de tradução.

A escolha dos textos teóricos para a fundamentação da presente tese deu-se por duas vias. A primeira via foi seguir as pistas deixadas por Nin em sua própria obra. Dentre tais autores, aqui estão alguns que considerei mais expressivos: Carl Gustav Jung, que versa sobre os arquétipos, o inconsciente coletivo e a relevância dos sonhos na compreensão da subjetividade humana; as obras psicanalíticas de Otto Rank, que investigam a criação artística e a personalidade criadora; Gaston Bachelard e seus estudos sobre a natureza e a função do devaneio poético.

A segunda via deu-se por meio de uma pesquisa de autores cujas obras tivessem pontos de contato e que dialogassem com a escrita de Nin. Os seguintes autores foram fundamentais na elaboração da tese por situar a obra da autora em um contexto mais amplo. Walter Benjamin, no ensaio A tarefa do tradutor, compartilha da mesma noção 
que Nin acerca da natureza da linguagem poética e da função da obra de arte. Já em Surrealismo: o último instantâneo da inteligência européia, Benjamin destaca algumas ideias do movimento Surrealista que foram essenciais na formação artística de Nin.

\section{Harold Bloom, em Genius: A Mosaic of One Hundred Exemplary Creative} Minds, ao exaltar o espírito criador e a capacidade imaginativa do homem, apresenta uma visão da criação artística em total sintonia com as ideias de Nin. Para ambos, as obras de arte seriam, essencialmente, um testemunho da emancipação espiritual do artista e não testemunho de uma determinada época ou de um determinado estilo como querem certas vertentes críticas. $\mathrm{O}$ autor encontra-se vivíssimo na obra e ela só existe porque há uma vontade criadora que a antecede. Toda obra de arte é uma manifestação do gênio do autor.

Outro autor que merece destaque é Octavio Paz. A narradora de $A$ casa do incesto, acerca de um dos personagens, declara: "somos irmãos na escrita". O mesmo pode-se afirmar sobre Nin e Octavio Paz: são irmãos na escrita. Paz, em $O$ arco e a lira e A dupla chama: amor e erotismo, ao discutir a relação entre a poesia, o erotismo e o sagrado, toca em questões centrais do pensamento de Nin que estão na base da construção de seu universo ficcional.

Na experiência da poesia, do amor e do sagrado, "o homem é arrancado de si" e se descobre um outro, ou outros. São acontecimentos fundamentalmente marcados pela revelação da estranheza e do assombro que sentimos diante de nós mesmos, da nossa fraqueza e grandeza, dos nossos abismos e transcendências. É o dar-se conta de que somos feitos de matéria paradoxal e ambivalente. Somos "isto e aquilo". "O paradoxo pertence ao bem espiritual mais elevado", 4 observa Jung. O desejo que nunca cessa e que nunca sabemos direito nomear, ${ }^{5}$ não seria uma busca por conciliar todas as forças opostas que sustentam a vida em nós, ou seja, a busca por um estado de unidade, repouso e quietude? Estado esse que alude a nossa condição original antes da separação da consciência?

A sensação que acompanha o homem ao ser lançado no tempo, ou melhor, a sua queda no tempo, é a sensação de desamparo. Tanto a poesia, o amor e o sagrado

\footnotetext{
${ }_{5}^{4}$ Jung, Psicologia e Alquimia, p. 28.

5 Aqui, me ocorre uma frase de Caetano Veloso, da canção Pecado original: "a gente não sabe o lugar certo de colocar o desejo".
} 
apontam para algo que está além da nossa condição de desamparados. Algo que não pertence ao fluxo do tempo e que, portanto, é atemporal e se faz presente quando essas três forças se manifestam em sua plenitude, por mais fugazes que sejam esses momentos.

Sempre me senti bastante intrigada pelo fato de que, os verbos correspondentes na língua inglesa para "lembrar-se" sejam "remember" e "recollect". Existe algo aqui no plano do significante que salta aos olhos. Literalmente, "remember" significa colocar os membros novamente em seu lugar, ou seja, "remembrar" e "recollect" significa recolher. O ser humano, em sua condição de desamparo, pois preso ao fluxo do tempo, é apenas um fragmento de um "eu" muito maior. "Não somos nós mesmos, cada um de nós, fragmentos, e a vida não é apenas um fragmento de um processo cósmico muito maior?", 6 pergunta Otto Rank no prefácio que escreveu para o diário de juventude de Nin. Ao cair no tempo, o ser humano torna-se consciente de sua incompletude e falta. Para que recobre novamente sua totalidade é preciso que ele recolha partes de seu corpo que foram perdidas e passe por um processo de "remembramento".

Segundo Octavio Paz, a poesia, o erotismo e o sagrado comungam da mesma natureza e a linha que separa essas experiências é bastante tênue. "As três experiências são manifestações de algo que é a própria raiz do homem. Nas três pulsa a saudade de um estado anterior. E esse estado de unidade primitiva, do qual fomos separados, do qual estamos sendo separados a cada momento, constitui a nossa condição original". Tanto para Nin quanto para Paz, essas três manifestações são, essencialmente, uma forma de conhecimento. Esse conhecimento nos permite, em certas ocasiões, integrar novamente o nosso corpo. "O poema nos faz lembrar o que esquecemos: o que realmente somos". 8

Em Nin, o ser e o "mundo da vida" é sua matéria de exploração e investigação literária, aspectos estes que vão ao encontro das reflexões feitas por Milan Kundera sobre a natureza do romance. No primeiro capítulo do livro, A arte do romance, o autor retoma as ideias de Edmund Husserl e Martin Heidegger sobre a produção e forma de transmissão do conhecimento na modernidade. Para estes filósofos, a humanidade vive

\footnotetext{
${ }^{6}$ Rank, “On the Early Diary: A Preface”. In: Stuhlmann. Anaïs International Journal Volume 2, p. 20. Are we not fragments ourselves, each one of us, and is not life itself just a fragment of some bigger cosmic process?

${ }^{7}$ Paz, $O$ arco e a lira, p. 143.

${ }^{8} \mathrm{Paz}, O$ arco e a lira, p. 115.
} 
hoje uma crise sem precedentes gerada por uma visão cientificista em que o conhecimento é produzido e transmitido por meio de disciplinas cada vez mais especializadas, reduzindo "o mundo a um simples objeto de exploração técnica e matemática". Consequentemente, não é mais possível abordar o homem e o mundo em sua totalidade:

\begin{abstract}
A vida do homem está reduzida a sua função social; a história de um povo, a alguns acontecimentos, que por sua vez são reduzidos a uma interpretação tendenciosa; a vida social está reduzida à luta política e esta, à confrontação de apenas duas grandes potências planetárias. $\mathrm{O}$ homem se acha num verdadeiro turbilhão da redução, onde o "mundo da vida" de que falava Husserl se obscurece fatalmente e onde o ser cai no esquecimento. ${ }^{9}$
\end{abstract}

No entanto, Kundera defende a tese de que a literatura e mais especificamente o romance cumprem um papel de extrema relevância nos dias atuais, pois este se destina à reflexão da existência em sua totalidade. É o local par excellence onde a complexidade, os questionamentos sobre a vida são postos em cena, sendo sua natureza fundamentalmente subversiva, pois se recusa a prescrever fórmulas, receitas ou oferecer explicações simplistas. Neste sentido, o romance vai em direção oposta ao Zeitgeist de nossa época, marcado, sobretudo, pela presença avassaladora de um discurso predominante: o discurso midiático.

Ora, se a razão de ser do romance é manter o "mundo da vida" sob uma iluminação perpétua e nos proteger contra "o esquecimento do ser," a existência do romance não é, hoje, mais necessária que nunca? ${ }^{10}$

Todos os autores escolhidos para a fundamentação teórica da presente tese apontam caminhos alternativos para se pensar a escrita literária que se distanciam, em certos aspectos, da perspectiva apresentada pela crítica literária tradicional. Os estudos realizados pelo poeta Claudio Willer no Brasil, por Harold Bloom nos Estados Unidos e pelos escritores reunidos em torno da revista Temenos na Inglaterra, só para citar alguns, se destacam nesse novo cenário por compreenderem a obra literária como a afirmação da capacidade imaginativa do ser humano, como o resultado de uma entrega genuína à grande aventura do pensamento. $\mathrm{O}$ artista é o ser rebelado por excelência, ladrão do fogo sagrado que transcende as prisões ideológicas que tentam definir, classificar e conformar a experiência humana.

\footnotetext{
${ }^{9}$ Kundera, A arte do romance, p. 23.

${ }^{10}$ Ibid, p. 23.
} 
Por essas razões, tais estudiosos se recusam radicalmente a reduzir a análise das obras literárias a meras estruturas lingüísticas ou, então, a subjugá-las a um discurso cientificista. $\mathrm{O}$ antídoto que utilizam contra a aridez do pensamento é o cultivo da mesma sensibilidade, curiosidade e imaginação que está presente nos poetas. Harold Bloom incita todos aqueles que se dedicam à pesquisa literária a buscar novos conhecimentos e outras sabedorias, principalmente no campo filosófico-religioso, e recomenda a leitura de autores como Mircea Eliade, Ioan Couliano, Henry Corbin, Hans Jonas, Gershom Scholem, ${ }^{11}$ todos eles grandes exploradores do terreno fértil do sagrado, dos mitos e das religiões.

O que os estudos sobre mitos, Xamanismo, Gnosticismo, Cabala Judaica, Sufismo, Alquimia têm a dizer sobre a experiência poética? Em que ponto a voz do poeta se confunde com a voz do profeta visionário? Essas questões são bastante complexas e já foram tema de exploração de Octávio Paz, Robert Graves e Claudio Willer. Para Paz, a ideia de revelação é o que une essas diferentes formas de conhecimento. A revelação é sempre feita por meio de imagens, em linguagem altamente simbólica e mítica. "Os símbolos mais antigos da raça humana são a materialização de verdades antigas. Eles são frutos de uma maneira antiga de perceber o universo que se dá através da imaginação", 12 argumenta Henry Miller.

No mundo contemporâneo, em que as experiências humanas acontecem cada vez mais no nível superficial de consciência - entenda-se como nível superficial o foco na mente analítica que se preocupa em definir, classificar e delimitar -, a experiência poética é um refúgio de rebeldia. Nesse espaço, vozes e verdades arcaicas encontram novamente sua força expressiva na imagem. A imaginação e o desejo entram em cena como potências criadoras e relegam a mente racional ao papel de coadjuvante. E é por essa via que o poeta salta para o outro lado do espelho.

Ao atravessar o espelho, algo se rompe e o poeta abandona o mundo da história ${ }^{13}$ e das ideologias para adentrar camadas mais profundas da consciência. Na linguagem

\footnotetext{
${ }^{11}$ Outro grande estudioso das religiões e dos mitos que merece ser acrescentado na seleção feita por Bloom é Joseph Campbell. Em A Skeleton Key to Finnegan's Wake: Unlocking James Joyce Masterwork, Campbell deu uma grande contribuição ao analisar a maneira como Joyce se apropria de certos mitos na criação de sua narrativa.

${ }^{12}$ Miller, The World of Lawrence, p. 21. The oldest symbols of the race are the embodiment of the oldest truths. They are the product of the oldest way of looking at the universe, which is imaginatively.

${ }_{13}$ Aqui, me recordo de uma frase de James Joyce: History, Stephen said, is a nightmare from which I am trying to awake. "A história, disse Stephen, é um pesadelo do qual tento acordar".
} 
Jungiana, este é o momento em que a consciência se aproxima dos arquétipos que são, em sua essência, imagens primordiais. "Quando, mediante a exploração do inconsciente, a consciência se aproxima do arquétipo, o indivíduo é confrontado com a contradição abissal da natureza humana, o que lhe proporciona uma experiência imediata da luz e das trevas, do Cristo e do demônio". ${ }^{14} \mathrm{O}$ artista, diz Jung, entra em contato com as imagens primordiais para criar seu próprio universo e é nesse movimento de criação que ele encontra uma maneira de compensar sua insatisfação com a pobreza e esterilidade espiritual de seu tempo.

Em relação à fortuna crítica de Nin, dois estudos realizados em épocas diferentes se destacam por dar contribuições importantes e abrir novos caminhos para se pensar sua escrita: The Mirror and the Garden: Realism and Reality in the Writings of Anaïs Nin, de Evelyn J. Hinz, e Anaïs Nin: Literary Perspectives, organizado por Suzanne Nalbantian. O primeiro estudo, publicado em 1973, é uma referência na crítica de Nin por ter sido a primeira tese acadêmica escrita sobre sua obra. O segundo texto, de 1997, reúne vários ensaios agrupados em diferentes temas, e sua relevância está no fato de que serviu como um resgate dos estudos da poética de Nin.

E porque a palavra resgate? Vale apena ressaltar que, de 1985 em diante, volumes do diário original começaram a ser publicados, o que causou uma reviravolta na abordagem de sua obra. Nas palavras de Ana Balakian, a tendência da crítica, desde então, infelizmente, tem sido de lançar mais sombras do que luz sobre o universo ficcional de Nin. Textos sensacionalistas e tendenciosos, preocupados somente com a exploração de sua vida íntima, ocuparam o espaço da análise literária criteriosa. Nin foi e continua sendo alvo de julgamentos moralistas. E, aqui, menciono a publicação de duas biografias - Anaïs Nin: A Biography, de Deirdre Bair e The Erotic Life of Anaïs Nin, de Noël Riley Fitch - que contribuíram ainda mais para alimentar essa visada sensacionalista.

Se por um lado, a publicação dos diários em sua íntegra suscitou leituras equivocadas, por outro lado, a publicação foi crucial na compreensão de seu universo ficcional. Eles são as peças chaves que faltavam para finalizar a montagem de um enorme quebra-cabeça. A tese que gostaria de levantar em relação à escrita de Nin é de que o conjunto de sua obra compõe um único livro.

\footnotetext{
${ }^{14}$ Jung, Psicologia e Alquimia, p. 31.
} 
Nin escrevia e reescrevia compulsivamente. O diário começa a ser escrito aos onze anos de idade e só tem fim com sua morte, aos setenta e três anos. Nin hesitou muito na publicação dos diários, pois temia expor sua própria vida e, também, a vida de vários outros artistas, amigos, amantes, maridos e familiares. A fórmula que encontrou para driblar essa dificuldade foi submeter o diário original a um processo de ficcionalização para que, então, os seus livros pudessem vir a público.

Como grande escritora que era, Nin lança mão de várias estratégias literárias no processo de reescrita e termina por embaralhar as fronteiras entre os gêneros literários. Todos os livros de ficção que publicou foram resultado desse experimento realizado com o diário original, com exceção dos primeiros contos escritos na juventude e dos contos eróticos. "Existe regras na literatura de como as coisas devem ser escritas em uma ordem lógica, mas aqui eu quero que você saiba que eu escrevo meu diário em violação a todas as regras do universo", ${ }^{15}$ comenta Nin, aos dezesseis anos, em um dos diários de juventude. É interessante notar o caráter premonitório dessa afirmação. Inúmeras foram as regras que Nin viria violar ao longo de sua vida, não apenas de natureza literária. Para todo grande artista, criação e destruição caminham lado a lado, pois só assim existe a possibilidade de surgimento do novo e do inesperado.

Após anos de relutância, Nin finalmente consegue superar o conflito em relação aos diários e encontra um editor interessado em publicá-los. A fórmula que utilizou para preservar sua vida íntima foi, novamente, submeter o diário original ao mesmo processo de reescrita que havia realizado em sua obra de ficção. $\mathrm{O}$ diário original é editado, ficcionalizado e novas partes são acrescentadas. A Anaïs adulta, em muitos momentos, se funde com a Anaïs da juventude.

A edição do texto não ocorreu somente pelas mãos de Nin. A editora Harcourt exigiu de Nin que fosse em busca de todos os "personagens" do diário e obtivesse deles uma autorização para publicação. Nem todos consentiram com o que Nin havia escrito e, em função dessa recusa, o texto teve de ser reeditado. Cabe aqui ressaltar a grande generosidade de Henry Miller, companheiro literário e amante de Nin por mais de dez anos, que deu a ela toda liberdade para que publicasse o texto em sua íntegra e via com bastante humor as críticas, que por ventura, a protagonista fazia em relação ao seu

\footnotetext{
${ }^{15}$ Nin, Linotte: The Early Diary of Anaïs Nin 1914 - 1920, p. 259. Literature has rules about the way things should be written in logical order, but here I want you to know that I write my diary in violation of all the rules of the universe.
} 
personagem. Já o marido de Nin, Hugh Guiler, ${ }^{16}$ recusou-se a ser um dos personagens principais do diário.

Nin recebeu duras críticas da corrente feminista por ter apagado todas as referências de sua vida íntima do diário. Entretanto, não era a intenção de Nin expor sua vida e vidas de pessoas que lhe eram próximas. Todos os encontros importantes que marcaram a vida de Nin estão ali narrados, com a ressalva de que nada é dito explicitamente. E esse é o elemento que dá força e beleza literária a essa versão do diário. Tudo paira no ar, tudo é apenas sugestionado. Cabe ao leitor preencher os espaços vazios.

Em uma entrevista, Nin revela que a prática da escrita ficcional havia sido fundamental na reescrita dos diários. A partir de 1966, sete volumes que acompanham sua trajetória de 1931 a 1974 são lançados. Porém, nos últimos anos de vida, a autora expressou o desejo de que o diário viesse a ser publicado sem cortes, o que ocorreu em 1985, após a morte de seu primeiro marido, Hugh Guiler. Desde então, oito volumes foram lançados, sendo o último, Mirages, em 2013. Ainda há promessa por parte de sua editora Swallow Press de que um último diário, intitulado Trapeze, venha a ser publicado este ano.

O diário ficcionalizado e o diário original constituem em si experiências de leitura bastante distintas. Se no primeiro prevalece o tom sugestivo da narrativa, o refinamento da linguagem literária, e o lado luminoso da protagonista, no segundo tudo é narrado de maneira detalhada. Nin faz questão de não deixar nada oculto e não se permite nenhum tipo de censura. Verdades inconfessáveis são ditas. Sua alma é revirada ao avesso e todos os demônios estão à solta. Refiro-me, mais especificamente, aos volumes Henry and June, Incest e Fire, que compreendem os anos de 1931 a 1937. Nin reconhecia que o diário original representava sua própria sombra. Ele era um conjunto de todas as coisas que, conscientemente, se recusava a projetar em outras pessoas: raiva, queixas, ódio, veneno, explosões.

O ano de 1931 é crucial na vida de Nin: ano de grandes descobertas e de grande sofrimento emocional. Para quem acompanhou a trajetória da heroína Nin, ao longo dos

\footnotetext{
${ }^{16} \mathrm{O}$ marido de Nin, Hugh Guiler, também mantinha um diário e era comum entre eles ler o diário um do outro. Entretanto, houve um momento na vida de Nin em que isso não era mais possível e ela se viu forçada a criar um outro diário que pudesse compartilhar com o marido.
} 
diários, é como se ela tivesse sido tragada por um furacão e posta face e face com suas sombras e trevas. Esse é o ano da metamorfose e do confronto com os seus duplos. Durante esse período, além de conhecer Henry Miller e sua esposa, June Mansfield, Nin, também, reencontra seu pai, o pianista e compositor Joaquín Nin, após longos anos. Todos esses encontros foram catalisadores de intensas transformações na personalidade de Nin.

Para o leitor, a sensação que persiste durante a leitura dos diários de 1931 a 1937 é de incredulidade. Será que Nin realmente viveu todas essas experiências? Tudo não passa de invenção de uma mente pra lá de imaginativa, tentava me convencer em alguns momentos. Invenção ou não, isso não tem a menor importância. $O$ fato extraordinário é que tudo virou ficção na acepção mais elevada da palavra.

As três páginas seguintes traçam um brevíssimo panorama da publicação da obra de Nin e de sua trajetória.

\section{1 - UMA BREVE TRAJETÓRIA}

Nin nasceu nos arredores de Paris, em 1903 e passou a vida entre a França e os Estados Unidos. Com a separação de seus pais, aos onze anos de idade, sua mãe deixa a França e parte para Nova York levando consigo os três filhos. Durante a viagem de navio de quase um mês, frente à dor da ausência do pai e a expectativa de viver em um país totalmente desconhecido, Nin busca alento na escrita e inicia uma carta destinada a seu pai que, por sua vez, nunca foi enviada. Tal carta dá origem ao diário, um catatau de mais de trinta e cinco mil páginas, que chega ao fim somente em 1977, ano de sua morte.

Quando criança, o diário era tido como um confidente onde era possível registrar impressões de um novo mundo, novas pessoas, uma nova língua, anseios, angústias, alegrias, lembranças nostálgicas de um mundo que havia perdido e que se encontrava sob o jugo de uma terrível guerra. Com o passar dos anos, a escrita do diário ganha proporções bem maiores. 
Aos 23 anos, Nin muda-se novamente para Paris, onde permanece até a eclosão da Segunda Guerra Mundial. É durante o período de entreguerras que Nin vive a fase mais importante de sua vida em termos de criação artística. A atmosfera libertária e a efervescência cultural que envolvem Paris fazem da cidade um local privilegiado de encontro de vários artistas de diferentes partes do mundo. Nin trava contato íntimo com as ideias do movimento Surrealista e com a psicanálise, que teriam influência direta no caráter experimental e inovador de sua obra.

Foi também durante esse período que seus primeiros livros foram publicados: $D$. H. Lawrence: An Unprofessional Study (1932), House of Incest (1936) e Winter of Artifice (1939). Importante ressaltar que apesar de parte de sua obra ter sido publicada na França, Nin adotou o inglês como sua língua literária. Apenas os primeiros volumes do diário, que compreendem os anos de 1914 a 1920, foram escritos em francês.

Com a eclosão da Segunda Guerra Mundial, Nin retorna aos Estados Unidos. Para sua enorme tristeza, o clima literário norte-americano das décadas de 40 e 50 mostra-se completamente hostil a experimentalismos e inovações estéticas. Pouco se conhecia sobre o movimento Surrealista. A obra Nadja, de André Breton, que fora um marco para muitos escritores na Paris da década de 20, sequer havia sido traduzida nos Estados Unidos. ${ }^{17}$

A vertente literária que predominava era o Realismo Social. Os escritores, em sua maioria, estavam voltados para questões sociais e ideológicas e presos aos moldes do romance convencional. As grandes editoras, preocupadas apenas em satisfazer o gosto do público médio e obter lucros. Neste ambiente não havia espaço nem interesse pela prosa poética de Nin. "Literatura, a dádiva máxima para expressar os aspectos mais sutis do pensamento e das sensações humanas, poderá não sobreviver a essas perseguições: primeiro a religião, depois a burguesia, o marxismo, e agora o comércio". 18

Várias foram as tentativas frustradas de publicação. A forma que Nin encontrou para lidar com a indiferença e a rejeição por parte das editoras foi adquirir uma máquina de impressão manual e fundar sua própria editora. Em 1942, a Gemor Press lança uma

\footnotetext{
${ }^{17}$ Somente em 1968 é que foi realizada a primeira tradução de Nadja nos Estados Unidos.

${ }^{18}$ Nin, Diary III, p. 124. Literature, the ultimate gift for expressing the most subtle aspects of man's thoughts and feeling, may not survive persecution: first by religion, then by the bourgeois, then by Marxism, and now by commercialism.
} 
nova edição de Winter of Artifice e, em 1944, publica uma coletânea de contos sob o título de Under a Glass Bell. Algumas críticas são publicadas em jornais. No entanto, o clima de indiferença prevalece em relação a sua obra.

Nas décadas seguintes, Nin publica, por outras editoras, cinco romances: Ladders to Fire; Children of the Albatross; The Four-Chambered Heart; a Spy in the House of Love e Seduction of the Minotaur, que mais tarde viriam a constituir, em uma única edição, o romance chamado Cities of the Interior. E, em 1964, lança Collages, que a princípio seria um livro de contos, mas que acabou se tornando um romance experimental.

Na década de 40, Nin também se dedica à escrita de contos eróticos que foram publicados postumamente sob o título de Delta of Venus e Little Birds. Esses contos surgiram de forma bastante inusitada. Foram, na verdade, escritos sob encomenda para um misterioso colecionador de obras literárias que oferecia um dólar por página para o escritor que se interessasse em explorar o universo da sexualidade. Para Nin e, também, para muitos de seus amigos escritores, esta foi a grande oportunidade de driblar a difícil situação financeira em que se encontravam. Esses dois livros de contos se tornaram, mais tarde, referências dentro do gênero literatura erótica. E, principalmente no Brasil, Nin ficou muito mais conhecida pelos seus escritos eróticos do que pelos diários. ${ }^{19}$

Somente com a publicação do primeiro volume do diário, em 1966, é que Nin torna-se uma autora consagrada tanto pelo público quanto pela crítica. Seus livros são traduzidos para diversas línguas e teses acadêmicas começam a surgir sobre sua obra. Vários são os convites para palestras em universidades nos Estados Unidos, na Europa e no Japão. Também é convidada para trabalhar como orientadora de pesquisa na International Community College, na Califórnia.

Toda essa reviravolta na acolhida de sua obra deu-se, basicamente, pela mudança de mentalidade e pela revolução cultural que ocorreu na década de 60 e 70 . Os movimentos de contracultura em todo o mundo abriram caminhos para se pensar o ser

\footnotetext{
${ }^{19}$ A razão pela qual Nin ficou mais conhecida no Brasil como escritora de contos eróticos foi devido às poucas traduções existentes de sua obra. Apenas três volumes do diário foram traduzidos, em um total de quinze volumes: Henry \& June, Incesto e Fogo. Além desses três volumes, podemos encontrar em português as seguintes obras: um livro de ensaios, Em busca de um homem sensível; um livro de cartas, Anaïs Nin \& Henry Miller - Cartas de amor; dois volumes de contos eróticos, Delta de Vênus e Pequenos pássaros; o romance Uma Espiã na Casa do Amor; e uma edição que reuniu a novela Inverno de Artifício e o poema em prosa A casa do incesto, publicado sob o título de A casa do incesto e outras estórias.
} 
humano sob novos ângulos e novos paradigmas. Havia espaço para debater a condição da mulher e para questionar relações de poder em um mundo patriarcal. Dentro desse novo contexto, Nin foi aclamada como uma pioneira, pois sua obra era testemunho de uma mulher inteiramente comprometida com a liberdade individual e a criação literária.

Nin viveu intensamente o século 20, presenciou e escreveu sobre momentos importantes da história mundial. Sua trajetória de escritora e pensadora serviu de inspiração para muitas outras autoras. É importante lembrar que todos os protagonistas de suas estórias são mulheres artistas. E, como bem expressa Sharon Spencer, em Collage of Dreams, apesar de a obra de Anaïs Nin ter sido escrita do ponto de vista feminino e de tratar de muitas questões do universo feminino, os homens também têm muito a aprender com sua literatura. Certamente, sua obra transcende questões de gênero.

Com a publicação dos diários, Nin torna-se uma figura bastante requisitada para palestras e aulas em universidades. Apesar da saúde frágil - passou os dez últimos anos da sua vida lutando contra o câncer - ainda encontrou disposição para aceitar novos desafios e, em 1969, escreve um livro chamado The Novel of the Future, inspirado em seus debates acalorados junto aos estudantes universitários. Nesta obra, Nin descreve e analisa as principais ideias que nortearam seu projeto literário. Dentre os temas discutidos estão o movimento Surrealista, a psicanálise, as artes plásticas, filmes de Fellini e de Bergman, a noção de self e o processo criativo, a escrita do diário versus a escrita de ficção. Ao mesmo tempo em que versa sobre todos esses tópicos, lança, também, um olhar crítico em relação à sua própria obra. Ao final, presenteia o leitor com uma lista de sugestões de leitura.

\section{2 - ESCRITA LUMINOSA E SEDUTORA}

Meu primeiro contato com a escrita de Nin foi em 2010, por meio de uma coleção de correspondência entre Nin e o escritor Henry Miller. Ao ler a primeira linha, “Dostoevsky na Sibéria! Henry em Dijon! Da minha fortaleza, situada em paisagens de instintos glaciais (os suíços), de onde não tento recuperar minha sanidade, mas sim, o 
poder de esconder minha loucura", ${ }^{20}$ fui tomada por uma forte sensação de que teria de ler tudo que Nin havia escrito. Em um segundo momento, após certa familiaridade com sua escrita, senti uma forte necessidade de escrever sobre essa experiência de leitura. E logo depois, não pude conter o impulso de traduzir House of Incest para o português. E, assim, já se passaram seis anos de dedicação diária.

O interessante dessa estória é que, quando tive a oportunidade de compartilhar parte da minha pesquisa da tese de doutorado na disciplina Estágio Docente, percebi que os alunos respondiam exatamente da mesma maneira como eu havia respondido no primeiro contato com a escrita de Nin. Ao finalizar a leitura de uma passagem de um de seus livros, uma aluna diz: "Eu preciso ler tudo que essa autora escreveu".

Certamente, Nin desperta algo em nós que está adormecido. A luminosidade de sua escrita é quase palpável. Eros é o deus que rege seu espírito criativo. Sua capacidade de criar imagens, de intuir e de analisar, para além de limites conhecidos, seduz o leitor e o conduz por caminhos insuspeitos. Tudo com o propósito de tocá-lo emocionalmente e alterar sua visão.

O poema, A casa do incesto, particularmente, exerceu um enorme fascínio sobre mim. E a cada leitura, as imagens se tornavam mais poderosas e evocavam mais e mais sensações. E essa é a beleza da poesia: não precisar de explicação. Nas palavras de Octávio Paz, "O sentido do poema é o poema em si. As imagens são irredutíveis a qualquer explicação e interpretação". ${ }^{21}$

O meu intuito, ao abordar A casa do incesto, não é de realizar uma análise meramente intelectual do poema, mas sim de trazer elementos que possam iluminá-lo sob diferentes ângulos. E que esses elementos possam abrir caminhos na sensibilidade daqueles que, porventura, venham a se interessar pela obra de Nin. Nesse aspecto, a tarefa do crítico está muito próxima dos afazeres do poeta.

"Poesia não é para compreender é para incorporar. (...) Filosofia, razão e lógica não dão conta de todas as sensações. A poesia foge de explicações. A poesia se dirige à percepção sensível. Nunca quis dar informações. Quero dar encantamento”. Essa é uma

\footnotetext{
${ }^{20}$ Nin, A Literary Passion: Letters of Anaïs Nin and Henry Miller 1932-1953, p. 1. Dostoevsky in Siberia! Henry in Dijon! From my fortress up in the place of frozen instincts (the Swiss) where I am not trying to find sanity but the power to conceal my madness.

${ }^{21}$ Paz, $O$ arco e a lira, p. 116.
} 
fala de Manoel de Barros, do documentário Só dez por cento é mentira, que deixa bem claro que dar encantamento é a função do poeta. Ao invés de se ocupar somente com o exercício analítico da poesia, não deveria o crítico, também, aceitar o desafio e fazer de sua escrita um exercício de encantamento?

Antes de finalizar essa breve introdução, gostaria de ressaltar que todas as traduções das citações em inglês foram feitas por mim. Para os leitores familiarizados com a língua inglesa, fiz questão de incluir o texto original em nota de rodapé. 
Como se forma o espírito forte (esprit fort)? Este é, num caso particular, o problema da produção do gênio. De onde vem a energia, a força inflexível, a perseverança, com que alguém, opondo-se à tradição, procura um conhecimento inteiramente individual do mundo?

Friedrich Nietzsche, Humano, demasiado humano

Durante a música, meditei sobre a minha morte. Dei-me conta de que preciso completar a minha obra, pois sou um instrumento a serviço da consciência humana e um instrumento constantemente disciplinado a criar. ${ }^{22}$

Anaïs Nin, Diary $V$

\section{1 - A POÉTICA DE ANAÏS NIN}

Walter Benjamin, em seu ensaio, A tarefa do tradutor, rejeita o caráter instrumental e comunicativo da arte. Essa não seria sua função. Para ele, a obra de arte constitui uma experiência em si mesma. No caso da experiência poética, a linguagem não é veículo, não é meio, não é instrumento, mas local insubstituível em que a força da língua, sua energia vital, se manifesta plena de mistério e inapreensibilidade. Nin, tal qual Benjamin, insiste no fato de que a verdadeira função da obra literária seria de conduzir o leitor a uma jornada emocional. E é por essa razão que o discurso poético literário possui uma aura inteiramente diferente da de outros discursos. Para a autora:

\footnotetext{
Em se tratando de prosa poética, há uma demanda no que diz respeito aos nossos sentidos e à nossa imaginação. A intenção ao explorar a dimensão mágica das palavras é de convidar a participar. Caso prefira-se objetividade, que se leiam textos de história, psicologia, filosofia e ciência. A ficção tem um propósito diferente. A função do romance é conduzir o leitor a uma experiência emocional e colocá-lo em contato direto com vidas que, de outro modo, seria impossível vivê-las. A intenção da escrita é arrebatar o leitor como em um ritual. ${ }^{23}$
}

\footnotetext{
${ }^{22}$ Nin, Diary I, p. 102. During the music I meditated on my personal death. I realized I must complete my work, because I am an instrument for human consciousness and an instrument constantly disciplined to create.

${ }_{23}$ Nin, The Novel of the Future, p. 168. In poetic prose a demand is made upon our senses and imagination. The magic use of words is intended as an invitation to participate. If one prefers objectivity
} 
O universo literário de Nin se assemelha a um ritual cuidadosamente elaborado por meio de uma linguagem que busca traduzir a complexidade da psique humana. $\mathrm{O}$ grande interesse da autora é desvendar o mundo da subjetividade. Tal investigação é realizada a partir da junção da intuição, da razão, dos sentidos e da imaginação. As reflexões encontradas na primeira página de seu livro, D. H. Lawrence: An Unprofessional Study, um estudo crítico sobre a obra do escritor inglês D. H. Lawrence, são bastante elucidativas e podem perfeitamente ser aplicadas à sua própria escrita. No trecho seguinte, a autora nos fornece a chave para adentrar seu universo e, também, nos diz muito sobre em que estado de espírito deve se encontrar o seu leitor ideal. Onde estiver escrito D. H. Lawrence, leia-se Anaïs Nin:

\begin{abstract}
Não é possível entrar no mundo criado por D. H. Lawrence somente por meio de uma única faculdade. Deve haver um desejo triplo de intelecto, de imaginação e de sensação física, porque seu mundo foi erigido a partir da fusão de conceitos, de uma filosofia que era contra a divisão, de um apelo por uma visão do todo: "ver com a alma e o corpo" [...] sua filosofia não era uma fórmula friamente construída, uma junção de teorias que razoavelmente se encaixavam: era uma transcendência de valores comuns, a serem vivificados e fecundados pelo instinto e pela intuição. Tanto Lawrence quanto seus personagens foram submetidos a essa razão intuitiva. Assim, para começar a entender Lawrence é preciso, sobretudo, começar a ver a filosofia não como um mero edifício intelectual, mas como uma experiência viva e apaixonante. A leitura de Lawrence deveria ser uma busca de suas intuições ao limite de suas possibilidades, uma penetração em um mundo que nos conduzirá a uma viagem prodigiosa. Será uma viagem prodigiosa porque ele se rende completamente à experiência, ele permite que ela o atravesse, e porque ele tem aquela qualidade de gênio que extrai de experiências comuns essências estranhas ou desconhecidas ao homem. ${ }^{24}$
\end{abstract}

Nin defendia a ideia de que a verdadeira literatura não se destina a ser mero entretenimento ou passatempo, mas que teria um papel fundamental na formação do ser

one should read history, psychology, philosophy, science. Fiction has a different purpose. The function of the novel is to give you an emotional experience. To put you in direct contact with lives you may not otherwise have a chance to live. The writing is intended to sweep you along like a ritual.

${ }^{24}$ Nin, D. H. Lawrence: An Unprofessional Study, p. 13. The world D. H. Lawrence created cannot be entered through the exercise of one faculty alone: there must be a threefold desire of intellect, of imagination, and of physical feeling, because he erected his world on a fusion of concepts, on a philosophy that was against division, on a plea for whole vision: "to see with the soul and the body" [...] his philosophy was not a coolly constructed formula, an assemblage of theories fitting reasonably together: it was a transcending of ordinary values, which were to be vivified and fecundated by instincts and intuitions. To such intuitional reasoning he submitted himself and all his characters. Thus to begin to realize Lawrence is to begin immediately to realize philosophy not merely as an intellectual edifice but as a passionate blood-experience. Reading Lawrence should be a pursuit of his intuitions to the limit of their possibilities, a penetration of his world through which we are to make a prodigious voyage. It is going to be a prodigious voyage because he surrenders fully to experience, lets it flow through him, and because he had that quality of genius which sucks out of ordinary experience essences strange or unknown to men. 
humano. O escritor, ao recriar outra dimensão possível da realidade, um novo modo de percepção que transcende o habitual, deve ser capaz de conduzir o leitor a uma viagem em que a própria visão de si, e consequentemente, sua visão de mundo, sejam alteradas. Um conhecimento novo deveria surgir dessa aventura, "as velhas formas do viver" deveriam ser renovadas. "Tudo o que nos ensinaram é falso", afirmava Rimbaud em relação ao mundo da cultura e ao projeto de civilização européia.

Tanto para Rimbaud quanto para Nin, o poeta é o visionário, o profeta, o sacerdote que traz consigo o dom da transmutação, sendo a palavra transmutar uma das palavras amuletos que Nin tanto apreciava. Dizia que todas as palavras que se iniciavam com prefixo trans, que significa mudança e movimento, possuem uma força mágica latente: transmitir, transformar, transpor, transfigurar, transcender. O poeta é, também, aquele que sabe que o mundo é um grande livro a ser lido e decifrado.

\begin{abstract}
De todos os lados, os sentidos das coisas me fitam feito um enorme fantasma à espreita. O sentido emerge de becos úmidos e de faces sombrias e debruça-se nas janelas de casas estranhas. Reconstruo sem parar o modelo de algo que se perdeu para sempre e que não consigo esquecer. Agarro nas esquinas os cheiros do passado e tenho consciência dos homens que irão nascer amanhã. Por detrás das janelas ou há inimigos ou adoradores. Nunca neutralidade ou passividade. Sempre intenção e premeditação. Até as pedras têm para mim expressões druídicas. ${ }^{25}$
\end{abstract}

Na visão de Nin, o trabalho do escritor deveria se assemelhar ao trabalho de um cientista que se dedica a realizar constantes experimentos. A psicanálise e a física moderna revolucionaram o conhecimento acerca da natureza humana e das noções de espaço e tempo. Assim, espera-se que novas linguagens artísticas possam surgir a partir dessas descobertas. Em uma entrevista de 1968, Nin comenta: "É estranhamente curioso que escutemos jazz, apreciemos pintura moderna, moremos em casas modernas com design moderno, viajemos em aviões a jato, e mesmo assim continuemos a ler romances escritos em um estilo que não pertence a nossa época e que não se relaciona com

\footnotetext{
${ }^{25}$ Nin, House of Incest, p. 24. Significance stares at me from everywhere, like a gigantic underlying ghostliness. Significance emerges out of dank alleys and somber faces, leans out of the windows of strange houses. I am constantly reconstructing a pattern of something forever lost and which I cannot forget. I catch the odors of the past on street corners and I am aware of the man who will be born tomorrow. Behind windows there are either enemies or worshipers. Never neutrality or passivity. Always intention and premeditation. Even stones have for me druidical expression.
} 
nenhuma dessas influências. [...] o novo romance poderia nascer de Freud, de Einstein, do jazz e da ciência". ${ }^{26}$

O domínio da arte seria responsável por velar pelos mistérios do ser e da existência. A figura do artista seria a encarnação do herói nos tempos modernos. Não é por outro motivo que Nin se dedicou a escrever sobre os artistas. $\mathrm{O}$ artista é aquele que se permitiu morrer e renascer várias vezes em vida, que sofreu várias metamorfoses e que conseguiu transmutar todas essas experiências em formas artísticas. Aqui, a noção de estilo está, sobretudo, relacionada à força imaginativa e visionária do artista e sua capacidade de traduzir esta dimensão em linguagem. "Estilo é uma questão de visão e não de técnica", ${ }^{27}$ apontava Proust.

Nin foi fortemente atraída pela psicanálise, era profunda conhecedora e admiradora da obra de Freud, Jung, e principalmente Otto Rank, com quem teve a oportunidade de conviver intimamente, primeiramente como paciente, depois trabalhando como psicanalista sob sua orientação na década de 30. Rank, a quem Nin se referia como sendo o único homem metafísico que havia encontrado no mundo da psicanálise, foi colaborador de Freud por mais de vinte anos e grande parte de sua obra é dedicada à investigação da natureza criativa do homem.

Além de psicanalista, Rank era também homem de letras e tinha na literatura uma enorme fonte de conhecimento. Foi um profundo estudioso dos mitos, do folclore, do tema do incesto e do duplo. Suas obras Art and Artist: Creative Urge and Personality Development e Truth and Reality, infelizmente não traduzidas para o português, foram um divisor de águas na formação de Nin. Em Art and Artist, Rank analisa a força criadora humana desde seus primórdios, sendo esta a responsável pela transição do homem do domínio da natureza para sua inserção no mundo da civilização.

Para Rank, o surgimento de objetos de arte, da arquitetura, da linguagem e dos mitos está ligado a uma dimensão ritualística e sagrada, em uma tentativa dos primeiros povos de transplantar uma ordem macrocósmica ao plano terrestre. Já na modernidade,

\footnotetext{
${ }^{26}$ Nin, The Novel of the Future, p. 29. It is a curious anomaly that we listen to jazz, we look at modern paintings, we live in modern houses of modern design, we travel in jet planes, yet we continue to read novels written in a tempo and style which is not of our time and not related to any of these influences. $[\ldots]$ It ( the new novel) could be born of Freud, Einstein, jazz, and science.

${ }^{27}$ Nin, The Novel of the Future, p. 83.
} 
a criação artística estaria relacionada ao desenvolvimento da personalidade e à noção de imortalidade.

Em sua teoria da personalidade, Rank classifica os homens em três diferentes categorias: os adaptados, os neuróticos e os criadores. Para os adaptados, a noção de imortalidade estaria associada à procriação, ao passo que para os criadores a ideia de imortalidade está ligada à esfera individual. Rank observa que a primeira obra de cada grande artista está na criação de sua própria personalidade, por ser o artista aquele que conseguiu explorar camadas mais profundas da psique, que cultivou outras formas de percepção e que, acima de tudo, não se definiu a partir de máscaras sociais, ou seja, que não estabeleceu uma relação direta de identificação com sua persona.

A obra de arte seria uma expansão e uma materialização do mundo subjetivo do artista. Rank afirma: “A obra de arte é um símbolo externo de um profundo processo psicológico pelo qual passa o artista. Finalmente, ele consegue aceitar sua necessidade humana e inata de encontrar algo maior, fora dos limites do seu ser, que será o alicerce de sua vida neste mundo". 28

Em relação à condição do artista moderno, o crítico Wallace Fowlie, em The Age of Surrealism, compartilha das reflexões de Rank e acrescenta, ao dizer que a tarefa do artista seria de transpor seu universo singular para uma linguagem universal:

Em sua solitude, que é a sua herança, o artista moderno tem de saber que o universo que irá criar, seja por meio da escrita ou da pintura, está dentro de si mesmo. Ele sabe que seu mundo é singularmente pessoal e único e, também, universal. Encontrar dentro de si o que é original e, ao mesmo tempo, traduzilo em termos universais e transmiti-lo, tornou-se a ansiedade e a tarefa do artista moderno. $^{29}$

De acordo com Evelyn Hinz, a preocupação do artista na modernidade está centrada na compreensão de sua própria subjetividade e na busca de uma linguagem que possa exprimir essa dimensão interna. "O artista, sua arte e seu mundo estão

\footnotetext{
${ }^{28}$ Rank, Art and Artist, p. 420. The work of art is but the outward symbol of a profound psychological process within the artist whereby he manages finally to come to terms with an inborn human need to find something other and larger, outside the boundaries of the self, which he can then turn to account as the basis for living his life in the world.

${ }^{29}$ Fowlie, Age of Surrealism, p. 29. In his solitude, which is his inheritance, the modern artist has had to learn that the universe which he is going to write or paint is in himself. He has learned that this universe which he carries about in himself is singularly personal and unique as well as universal. To find in one's self what is original and at the same time what can be translated into universal terms and transmitted, became the anxiety and the occupation of the modern artist.
} 
intimamente interligados e as respectivas perguntas, quem sou eu? o que é a vida? o que é a arte? são respondidas simultaneamente". ${ }^{30}$ Estas, também, são questões fundamentais que norteiam a obra de Nin. Contudo, é necessário ressaltar que sua arte não se limita à esfera pessoal. Nin realiza com maestria, em sua escrita, a transição de um plano singular, que caracteriza suas vivências, para outro plano de caráter mítico e simbólico:

\begin{abstract}
O tema do diário diz respeito ao universo pessoal, mas isso não significa que seja apenas uma estória pessoal [...]. A dimensão pessoal se for profunda o bastante, se torna universal, mítica, simbólica. A vida pessoal vivida profundamente se transforma em verdades que vão além delas mesmas. ${ }^{31}$
\end{abstract}

Dentre os temas universais que perpassam a escrita de Nin, estão o incesto, as metamorfoses do eu, a busca de conhecimento, a busca pelo pai, sendo esse último tema um dos fios condutores mais significativos de sua obra, pois se encontra na própria gênese do diário. Em seus primórdios, o diário era apenas uma carta a ser enviada ao pai com o propósito de convencê-lo a voltar para casa. Esse evento singular e de ordem pessoal ganha contornos universais e a busca pelo pai se transforma em uma busca metafísica.

\begin{abstract}
Creio que não estou procurando por um homem, mas por um Deus. Estou começando a sentir um vazio que deve ser a ausência de Deus. Pedi por um pai, um guia, um líder, um protetor, um amigo, um amante, mas algo ainda me falta: deve ser Deus. Mas eu quero um Deus em carne e osso, não uma abstração. Um Deus encarnado, forte, com dois braços e um sexo. Talvez eu tenha amado o artista porque a criação é o mais próximo que conseguimos chegar do sagrado. ${ }^{32}$
\end{abstract}

Outro aspecto fundamental na poética de Nin é a fusão entre vida e arte. “Aquilo que criamos com as mãos e a fala de nada serve. O que realmente conta é aquilo que criamos a partir de nossa existência. Somente quando nos tornamos parte da

\footnotetext{
${ }^{30}$ Hinz, The Mirror and the Garden: Realism and Reality in the Writings of Anaïs Nin, p. 7. The artist, his artifact, and his world become inextricably related; the respective questions, who am I? what is art? what is life? are answered simultaneously.

${ }^{31}$ Nin, Diary $I V$, p. 153 . The theme of the diary is always the personal, but it does not mean only a personal story [...]. The personal, if it is deep enough, becomes universal, mythical, symbolic. The personal life deeply lived always expands into truths beyond itself.

${ }^{32}$ Nin, Diary I, p. 202. I do not think I am looking for a man, but for a God. I am beginning to feel a void which must be the absence of God. I have called for a father, a guide, a leader, a protector, a friend, a lover, but I still miss something: it must be God. But I want a God in the flesh, not an abstraction, an incarnated god, with strength, two arms, and a sex. Perhaps I have loved the artist because creation is the nearest we come to divinity.
} 
criação é que começamos a viver", ${ }^{33}$ afirma Miller. Em Nin, a escrita literária está muito próxima de uma forma de estar no mundo que, necessariamente, passa pela via dos excessos: excesso de disposição, de percepção, de intuição, de razão, de imaginação, de vivência, de luminosidade, de leitura. "O caminho do excesso leva ao palácio da sabedoria", ${ }^{34}$ diz William Blake em um de seus aforismos. O conhecimento emana da experiência e do que dela é possível extrair.

Nin explica que a criação artística é um processo lento e gradual. Os momentos de inspiração só surgiriam, em toda sua beleza e grandeza, se o artista cultivasse, diariamente, novas formas de percepção. O inesperado e o maravilhoso só poderiam ser encontrados através de um longo e contínuo estado de alumbramento e acreditava que, no seu caso, a poesia seria a única linguagem capaz de traduzir esse estado. Para a autora, a vida afetava as pessoas de diferentes formas: algumas tinham uma postura de total passividade, enquanto outras se sentiam inteiramente estimuladas e ativas. Nin tinha sede de infinito e, por isso respondeu de maneira extrema ao fato de estar viva. Em sua recusa a se ajustar aos mundos que lhe foram apresentados, Nin direciona sua força vital para criar o seu próprio mundo.

No que diz respeito à fusão entre vida e obra, Nin descobriu em D. H. Lawrence uma grande fonte de inspiração e "incorporou" tudo o que conseguiu absorver de seu universo literário. Em seu artigo, The Mystic of Sex, publicado em 1930, como uma espécie de preparação do livro, D. H. Lawrence: An Unprofessional Study, Nin observa:

\begin{abstract}
Ele era, como todos os verdadeiros poetas, contra uma vida tépida, contra amores tépidos. Ressentia a falta de sentimento nas pessoas ou, o que era ainda pior, a falta de expressão para tais sentimentos; ele queria uma realização da vida física igual à da vida mental; ele queria despertar impulso e a clarividência de nossas intuições. ${ }^{35}$
\end{abstract}

Assim como Lawrence, Nin também escrevia com o intuito de "despertar impulso e a clarividência de nossas intuições" e ressentia enormemente a incapacidade

\footnotetext{
${ }^{33}$ Miller, The Time of the Assassins: A Study of Rimbaud, p. 130. What we create with hand and tongue is nothing; it is what we create with our lives that count. It is only when we make ourselves a part of creation that we begin to live.

${ }^{34}$ Blake, O matrimônio do céu e do inferno e O livro de Thel, p. 24 . The road of excess leads to the palace of wisdom.

${ }^{35}$ Nin, The Mystic of Sex: A First Look at D.H. Lawrence, p. 13. He was, like all true poets, against tepid living and tepid loves. He resented the lack of feeling in people, or what is worse, the lack of expression of such feelings; he wanted fulfillment of physical life equal to the mental; he wanted to reawaken impulse, and the clairvoyance of our intuitions.
} 
das pessoas de se expressarem emocionalmente. E, aqui, a voz de Nin e de Lawrence é a mesma voz de Álvaro de Campos quando diz: “Afinal a melhor maneira de viajar é sentir. / Sentir tudo de todas as maneiras. / Sentir tudo excessivamente, / Porque todas as coisas são, em verdade, excessivas / E toda a realidade é um excesso, uma violência / Uma alucinação extraordinariamente nítida". ${ }^{36}$

Em seu livro de estréia, Nin presta uma homenagem a Lawrence pela audácia com que o escritor viveu sua vida, por ter transcendido valores comuns e, sobretudo, por ter conseguido transmutar tudo isso em arte. Para Nin, Lawrence criou uma linguagem nova para a experiência amorosa que, até então, nenhum outro escritor tinha ousado criar. Em vários momentos do livro as personalidades dos dois escritores se fundem. Ao falar de Lawrence, Nin também refere-se a si mesma.

Tanto o pensamento literário de Lawrence quanto o de Nin têm como eixo central o conceito de livingness. Na falta de uma palavra correspondente em português, este conceito pode ser traduzido da seguinte forma: disposição, abertura interna, interesse e um estar sempre desperto para as coisas da vida, em um fluxo contínuo de transformações. Em relação ao conjunto de valores morais, Nin argumenta que esses deveriam sofrer constantes reavaliações e novas elaborações. Para o historiador da arte Élie Faure, a moralidade era um dos grandes obstáculos à criação: "É a imaginação do homem que desencadeia suas aventuras, e aqui o amor assume o papel principal. A moralidade repreende a paixão, a curiosidade, a experiência - os três estágios sangrentos que conduzem à criação". 37

Para Nin, a ideia de estabilidade seria outro grande obstáculo à criação. A personalidade criadora nunca permanece fixa em nenhum dos mundos que, porventura, venha a habitar: sempre se sentirá impulsionada a realizar novas descobertas e atraída por aquilo que é desconhecido e não familiar. A vida é um processo contínuo de vir a ser, estágios infinitos que devemos atravessar. Em seu modo de percepção, o grande erro das pessoas seria de querer eleger um único estágio e ali permanecer pelo resto de suas vidas.

\footnotetext{
${ }^{36}$ Pessoa, Fernando Pessoa: obra poética, volume único, p. 406.

37 Faure, The Dance Over Fire and Water, p. 98. It is the imagination of man that provokes his adventures, and love takes here the first place. Morality reproves passion, curiosity, experience, the three bloody stages which mount toward creation.
} 
Em Art and Artist, Rank argumenta que a criatividade está associada a um processo de "desaprendizado". Para que o artista afirme sua autonomia é preciso que ele destrua, em um sentido mais amplo da palavra, a visão de mundo que lhe foi dada. Ele tem que desaprender parte do conhecimento que lhe foi transmitido culturalmente para, então, reorganizá-lo à sua maneira. Sobre a questão da criação, Nietzsche observa em Assim falou Zaratustra: "Sim, meus irmãos, para o jogo da criação é preciso dizer um sagrado "sim"; o espírito, agora, quer sua vontade, aquele que está perdido para o mundo conquista seu mundo". 38

Em contraponto à figura do artista, está a figura do adaptado, que é aquele incapaz de desaprender. Infalivelmente, o adaptado irá obedecer todas as regras sociais. Sua vida é um esforço contínuo de adaptação e, por isso, nunca entrará em contato com sua força criativa. Já figura do neurótico é aquele que se perdeu no meio do caminho. Ele dá início ao processo de desaprendizado e tem consciência da sua força criadora, mas, logo em seguida, sucumbe aos sentimentos de medo e culpa, pois sabe que terá de se distanciar dos valores comuns.

É nesse movimento de afastamento da esfera coletiva que o artista cria espaço para cultivar sua singularidade e, ao contrário do neurótico, ele consegue superar os sentimentos de medo e culpa. Para Rank, todo ser humano passa a vida se debatendo entre o desejo de separação, relacionado ao impulso criativo, e o desejo de união, ligado à necessidade de pertencimento. O processo de amadurecimento de cada um irá depender da capacidade de harmonização entre esses dois pólos.

No caso do artista, a obra de arte assume a função de conectá-lo novamente à esfera coletiva, só que dessa vez, em um nível bem mais profundo. Muitas vezes, essa conexão é feita somente no fim de sua vida ou mesmo anos após sua morte. E por que, então, a obra de arte tem o poder de tocar a todos, de forma tão arrebatadora, se a princípio ela é fruto de um movimento de separação com o coletivo? Por ser o artista um apaixonado pelas formas invisíveis, pelo inominável e pelo transcendente. A obra de arte é o receptáculo do desejo de união do artista com forças maiores e, por isso, ela desperta algo em nós que está há muito tempo esquecido. A grande ambição artística de Nin era encontrar uma linguagem em que pudesse expressar tudo o que é apenas

\footnotetext{
${ }^{38}$ Nietzsche, Assim falou Zaratustra, p. 24.
} 
intuído, desejava capturar todas as nuances e sutilezas da nossa vida emocional e espiritual.

\begin{abstract}
Minha ambição, e sei que vou realizá-la, é escrever sobre coisas impenetráveis, inomináveis, indescritíveis; dar forma a pensamentos evanescentes, sutis e fluidos; e fortalecer valores espirituais que são apenas mencionados de maneira vaga e geral, uma luz que muitas pessoas seguem, mas não conseguem compreender; irei penetrar nesse mundo com olhos translúcidos e palavras transparentes. ${ }^{39}$
\end{abstract}

Nin e Henry Miller eram grandes entusiastas de Art and Artist. Juntos, leram e trocaram ideias sobre o livro e, para Nin, essa era uma das obras que gostaria de ter escrito. $\mathrm{O}$ fascínio que o tema da criação e da personalidade criadora exercia em ambos os escritores era tão grande que se viram impelidos a criar novas obras para dar vazão a suas reflexões: ao mesmo tempo em que Nin escreve A Casa do Incesto, Henry Miller escreve The World of Lawrence: A Passionate Appreciation. Nin opta pela escrita poética e Miller pela escrita ensaística. Miller enxergava em Lawrence a grande encarnação da personalidade criadora na modernidade, era o herói que teve de passar por várias provações e, ao fim, ser sacrificado para o bem comum. "Desde que a sociedade foi constituída, todos aqueles que procuraram dela se afastar, ou foram perseguidos ou ridicularizados", ${ }^{40}$ observa o filósofo Emil Cioran.

Através de sua capacidade visionária, o artista pressente que há potência de vida pulsando em outra direção, para além do mundo dos sistemas ao qual fora introduzido, seja ele de natureza social, econômica, religiosa, filosófica, educacional e até mesmo artística. "A existência está em outro lugar", 41 observa Breton. Na cosmologia do poeta William Blake, Urizen é o demiurgo - entidade decadente e secundária - responsável pela criação da matéria. Em uma das gravuras de Blake, Urizen ou your reason, cria o mundo com um compasso na mão. Ele é o deus Newtoniano das medidas que impõe limites, que sistematiza, que quantifica e que restringe. Suas leis estão incorporadas em duas instituições: a ciência e a religião. É importante esclarecer que Blake não se

\footnotetext{
${ }^{39}$ Nin, The Early Diary of Anaïs Nin volume four (1927 - 1931), p. 231. "My ambition, and I know I will reach it, is to write clearly of impenetrable, nameless, and usually undescribable things; to give form to evanescent, subtle and fluid thoughts; and to give force to spiritual values that are usually mentioned in a vague, general way, a light most people follow but can't really understand. I'm going to look into that world with clear eyes and transparent words.

${ }^{40}$ Cioran, A Short History of Decay, p. 159. Since society was constituted, those who sought to withdraw from it were persecuted or mocked.

${ }^{41}$ Citado por Willer em "Surrealismo: poesia e poética". In: GUINSBURG, LEINER. O Surrealismo, p. 312.
} 
opunha ao desenvolvimento da ciência, mas afirmava que havia algo de herético em seu fundamento, uma vez que pregava a separação entre a mente e o mundo externo.

Para Blake, a visão materialista do mundo se origina dessa divisão e esse havia sido o grande erro da civilização ocidental. Kathleen Raine, no artigo Science and Imagination in William Blake, diz que a intenção do poeta era de questionar a definição reducionista de homem, como sendo um mero corpo físico que absorve estímulos do mundo externo por meio dos sentidos. Em Blake, o fundamento da vida está na consciência que tudo percebe e vivencia. Ela cria realidades e, por isso, não há separação entre o mundo interno e externo. Para além de Urizen, o demiurgo acorrentado na matéria, existe "o verdadeiro homem" que é o "gênio poético", "o espírito profético", a imaginação.

De acordo com Raine, certas experiências só podem ser vividas por aqueles que percebem o mundo através da imaginação ativa, ou seja, por aqueles que têm acesso ao Mundus Imaginalis ou o imaginal, para usar dois termos criados por Henry Corbin, profundo estudioso do poeta Sufi Ibn Arabi (1165-1240) e de linhagens do misticismo iraniano. As definições desses termos são bastante complexas e, para aqueles que queiram se aprofundar no tema, sugiro a leitura do livro Alone with the Alone: Creative Imagination in the Sufism of Ibn Arabi. Por agora, vale a pena destacar pontos convergentes no pensamento de Corbin e Blake. Corbin argumenta que para compreender o que venha a ser imaginação é preciso esquecer tudo o que os filósofos aristotélicos disseram sobre esse assunto: a imaginação não é uma faculdade corpórea. Nem tão pouco diz respeito à definição moderna que a associa ao fictício e ao utópico. É por essa razão que Corbin se recusa a utilizar o termo "imaginário". Nas palavras do autor, o Mundus Imaginalis é tão real quanto o mundo dos sentidos e do intelecto.

Blake e Corbin definiam a imaginação como um corpo sutil, divino e eterno, a consciência suprema e, ao mesmo tempo, o local onde todos os seres habitam. Por isso, a afirmação de Blake de que a imaginação não é um estado, mas sim a própria existência humana. E é através dela que o homem conhece aquilo que é desconhecido. "o olho vê / a lembrança revê / e a imaginação transvê / é preciso transver o mundo, diz Manoel de Barros no documentário Só dez por cento é mentira.

Na mitologia de Blake, o mundo da matéria foi criado a partir da mutilação de um corpo uno e, durante esse processo, as figuras de Urizen, que representa a 
racionalidade e Los, a consciência intuitiva, foram separadas. Los ou o Eterno Profeta nunca deixará de se comunicar com o corpo original, ao passo que Urizen é o reino da morte, o inferno metafísico. A melhor palavra para caracterizar esse reino seria diabólico, que na acepção original da palavra significa separação. O oposto de diabólico é simbólico. Por isso, a linguagem simbólica do poeta tem o poder de colocar o mundo/a consciência novamente em seu eixo.

Na mesma linhagem de Blake encontra-se Lawrence. Para o escritor, a grande tragédia humana está no fato de que os homens morrem sem ao menos terem nascido. Em sua visão, o mundo é um gigantesco cemitério, em que a maioria dos homens vive uma vida que se assemelha a uma espécie de servidão voluntária. A salvação só seria possível para aqueles que despertassem novamente sua imaginação ativa. "Se negarmos nossa imaginação, se não tivermos nenhuma vida imaginativa, somos pobres vermes que nunca viveram". 42

Henry Miller foi outro autor que teceu considerações bastante iluminadoras sobre a questão da imaginação e a realidade. Costumava dizer que o universo ficcional criado pelos artistas é, em sua essência, muito mais real do que aquilo que chamamos de realidade. A realidade, como é compreendida pelo senso comum, seria apenas uma projeção mental daqueles que não possuem nenhuma imaginação. Para ele, a época em que vivemos se caracteriza por ser uma época realista, que aceita a vida como ela é. Entretanto, este realismo é fundamentalmente superficial e estático. "Aqueles que se orgulham do fato de aceitarem a vida como ela é são os próprios responsáveis por assassinarem a vida como ela é, porque as coisas nunca são, tudo está sempre em movimento, em fluxo contínuo. Aquele que aceita a presente condição aprisiona a vida. E hoje, esta é a nossa verdadeira vida: aprisionamento, permanência e morte estática" ${ }^{43}$

Grande parte dos personagens de Nin são artistas. Todos intensamente engajados no processo de desaprendizado como forma de libertação do mundo criado por Urizen. O artista, por um esforço contínuo e pelo cultivo da sua vontade de poder, atinge uma estranha lucidez que o permite se emancipar dos afazeres do mundo. E é por esse

\footnotetext{
${ }^{42}$ Lawrence, The Erotic Works of D. H. Lawrence, p. IX. If we deny our imagination, and have no imaginative life, we are poor worms who have never lived.

${ }^{43}$ Miller, The World of Lawrence: A Passionate Appreciation, p. 48. Those who pride themselves on the fact that they accept things as they are the very ones who are killing things as they are, because things never are, things are in movement, in flux continually. He who accepts the present condition is arresting life. And that is our real life today: arrest, permanency, static death.
} 
motivo que sua presença foi e continua sendo motivo de incompreensão. Tal emancipação só ocorre porque ele teve a audácia de questionar a natureza da ação.

A ação, como muitos a concebem, não é a vida - parafraseando Rimbaud. A contemplação e a criação é que seriam formas superiores de ação. Somente no plano simbólico e mítico, o artista encontraria a atmosfera propícia para que a alma se desenvolvesse. Cioran, com o humor que lhe é bastante peculiar, escreveu aforismos brilhantes sobre a questão da lucidez exacerbada do artista: "A lucidez é o único vício que nos torna livres - livres em um deserto". 44 "A lucidez não extirpa o desejo de viver - longe disso, a lucidez simplesmente nos torna inaptos para a vida". ${ }^{45}$ Para muitos autores, essa estranha lucidez do artista tem outro nome: gênio.

Harold Bloom é um desses autores e sua ideia de gênio está associada à sua visão de Gnosticismo. De forma bastante concisa, Gnosticismo seria, para Bloom, um conhecimento que liberta a mente criativa do processo histórico, do pensamento teológico e de qualquer divindade que não evoque o elemento imaginativo presente no ser humano. Em suas palavras, um Deus que esteja totalmente dissociado da potência criadora do homem é um "Deus Carrasco" anunciador da morte. Bloom foi buscar essa expressão "Deus Carrasco", em James Joyce, que no original é Hangman God. O Gnosticismo seria, então, a religião dos gênios literários, por afirmar que a verdadeira emancipação espiritual do homem só ocorre quando ele deixa de ser apenas criatura e se torna criador.

Nin foi uma artista que ousou viver a vida no plano mítico. No diário de juventude, que cobre o período dos onze aos dezessete anos, a jovem Nin deixa entrever, em suas reflexões e observações do cotidiano, uma sensibilidade estranhamente refinada e complexa. Sua força imaginativa, já presente em sua escrita, antecipa a grande escritora que viria a se tornar. É nesse mesmo diário que, aos treze anos, descreve um sonho premonitório, cujo teor diz muito sobre seu profundo envolvimento com a literatura.

A cena transcorre da seguinte maneira: Nin encontra-se sentada em um quarto. Uma senhora usando um vestido de veludo preto com cinto de diamantes adentra o

\footnotetext{
${ }^{44}$ Cioran, The Trouble with Being Born, p.12. Lucidity is the only vice which makes us free - free in a desert.

${ }^{45}$ Ibid, p. 175. Lucidity does not extirpate the desire to live - far from it, lucidity merely makes us unsuited to life.
} 
local, senta-se ao piano que ali está e começa a tocar uma música que deixa Nin profundamente emocionada. Em seguida, essa mesma senhora se aproxima de um cavalete, pega um pincel e, num piscar de olhos, pinta um quadro belíssimo. Logo após, a misteriosa senhora senta-se à escrivaninha, observa Nin atentamente, pega uma caneta e um livro de páginas em branco e, lentamente, começa a escrever páginas e mais páginas. Por fim, fecha o livro, caminha na direção de Nin e diz: "Agora você escolhe". A princípio, Nin hesita e, então, relembra a música tocada ao piano, revê novamente a pintura e depois, olha a escrivaninha coberta de livros. É nesse momento que sente uma força estranha a puxando para essa direção. A bela senhora sorri, vem até Nin com um grande livro e diz: "Escreva. Serei seu guia." Sem mais delongas, Nin pega a caneta, começa a escrever e não para mais.

Apesar da pouca idade, Nin já intuía o caráter singular de sua personalidade e constantemente se perguntava: "Será que eu sou como todo mundo?". Ou ainda, "Será que existe alguém que vai me entender? Eu não me entendo”. As passagens seguintes merecem ser citadas pela beleza poética com que expressava suas inquietações existenciais.

\begin{abstract}
O tempo nada faz com meus colegas de escola. Para mim, cada dia é uma novidade, e me parece que minha personalidade muda a cada dia. Se eu me levanto à mesma hora, cada dia eu tenho impressões diferentes. Mesmo quando eu uso o mesmo vestido, me parece que eu não sou a mesma menina. Mesmo quando eu repito as mesmas orações durante um ano, cada vez elas parecem ser diferentes na minha interpretação e eu entendo tudo de forma diferente. $^{46}$

Às vezes eu tenho sensações que não consigo explicar, impulsos que eu não consigo controlar, impressões que não me deixam em paz, sonhos e pensamentos contrários aos sonhos e pensamentos que as outras pessoas costumam ter. Quando leio um livro, discuto comigo mesma, critico, encontro suas qualidades e defeitos, tenho pensamentos tão profundos que fico perdida, cansada, já não me entendo mais. ${ }^{47}$
\end{abstract}

Não sou louca. As coisas que penso não são impossíveis. Não sou burra. Quem sabe um dia eu sirva pra alguma coisa. Se me entristeço facilmente é porque, como diz minha mãe, eu herdei uma alma dramática, mais dada à tristeza do que à alegria. Eu conto tantas estórias pro Thorvald e o Joaquin

\footnotetext{
${ }^{46} \mathrm{Nin}$, Diary I, p. 246. Time does nothing to my companions in school. For me each day is a novelty, and it seems to me that my character changes every day. If I do rise at the same time, I have different impressions each day. Even if I do wear the same dress, it seems to me that I am not the same girl. Even if I repeat the same prayers during one year, each time they appear different to my interpretation, and I understand them differently.

${ }^{47}$ Ibid, p. 247. At times I have sensations which I cannot explain, impulses I cannot control, impressions I cannot shake off, dreams and thoughts contrary to the usual dreams and thoughts of others. When I read a book I discuss it with myself, I judge it, I find its qualities and its faults, I begin to think such deep thoughts that I get lost, weary, I no longer understand myself...
} 
(irmãos mais novos de Nin), que a minha mãe disse que minha imaginação é igual às cataratas do Niágara em sua riqueza e movimento contínuo. ${ }^{48}$

Nin fez de sua vida um grande laboratório da alma. Realizou diversos experimentos com o propósito de alcançar sua independência social e espiritual. Aos dezesseis anos, abandona os estudos formais por causa das críticas que recebia de seus professores que insistiam em qualificar seu modo de escrever como "afetado". O escritor Robert Graves esclarece, em The White Goddess, que toda pessoa que passa pelo processo de educação formal terá sua faculdade poética atrofiada, caso não se esforce, por conta própria, em cultivá-la. Nin sabia, desde o início, que seu caminho seria feito de vários desvios e, que, muitas vezes, se afastaria da rota dos valores comuns.

O período que passou nos Estados Unidos de 1914 a 1927 foi inteiramente dedicado à leitura e à escrita. Nin opta por ser autodidata e é bastante influenciada pelo pensamento dos escritores Transcendentalistas. Casa-se com Hugh Guiler, que também cultiva interesses literários, era formado em Letras, e juntos compartilham grandes aspirações artísticas, que mais tarde vieram a se concretizar. Apesar de Guiler ter pouco tempo para se dedicar à arte, em função de seu emprego, tornou-se gravurista e cineasta reconhecido na década de 40.

Enquanto muitas mulheres da década de 20 - no auge do movimento feminista reivindicavam direitos igualitários, Nin repudiava a ideia de ter uma rotina de trabalho. $\mathrm{Na}$ adolescência, trabalhou como modelo vivo e, aos trinta e dois anos, como psicanalista, mas esses foram episódios breves em sua vida. O que realmente desejava, era ter todo o tempo livre para criar: criar novas formas de expressão e novas ilusões de realidade. Isso não quer dizer que Nin não tivesse conflitos em relação à sua situação financeira. Sempre acalentou o sonho de que seus livros pudessem ser sua fonte de sustento. E foi o que aconteceu, só que com muito atraso. Nin já estava prestes a morrer.

Se a característica mais marcante de Nin foi sua excepcionalidade, Hugh Guiler foi uma pessoa tão singular quanto Nin. Sua imensa generosidade e sensibilidade artística permitiram que Nin se dedicasse à criação literária sem ter que se preocupar

\footnotetext{
${ }^{48}$ Nin, Diary I, p. 247. I am not mad, I do not think of impossible things. I am not stupid. I may be good for something one day. And if I do get easily saddened, it is because, as my mother says, I have inherited a dramatic soul, more easily given to sadness than joy.
} 
com questões financeiras. Guiler também sustentou a mãe, o irmão e todos os artistas amigos de Nin que viviam na penúria. Depois de amargar períodos de total miséria em Paris, Henry Miller, só pôde realmente se dedicar à escrita quando conheceu Nin, em 1931. Nos dez anos seguintes em que estiveram juntos, não precisou se preocupar com sua sobrevivência. Assim como Nin, Miller só foi ter reconhecimento maior como escritor ao final da vida, muito pelo fato de suas obras terem sido proibidas, por um longo tempo, nos Estados Unidos. Nin costumava dizer que Guiler era o pai de todos. Ele nunca restringiu a liberdade de Nin e, por isso, ficaram casados por mais de 50 anos, até a morte da autora.

Entretanto, a questão dos relacionamentos amorosos foi motivo de grande conflito para Nin. Como conciliar a necessidade interna de crescimento, a vida em seu movimento contínuo de expansão e transformação, e a necessidade de pertencimento? Em Nin, o verdadeiro crescimento só é possível no encontro com o outro e na criação poética. Nin tinha sede de experiências, no sentido místico da palavra, queria sentir o gosto do infinito no aqui e agora, encarnada em um corpo. Por isso, subverteu noções de espaço e tempo e construiu uma realidade bem mais ampla, em que várias vidas pudessem ser vividas simultaneamente. Em suas palavras, queria encontrar uma maneira de compensar a tristeza que sentiu, quando criança, ao saber que tínhamos apenas uma vida. Nin, também, pôs em prática dois conselhos dados pela escritora e psicanalista Lou Andreas-Salomé (1861-1937), que tanto admirava: "Ousa tudo, não tenhas necessidade de nada" e "A vida te dará poucos presentes, acredita: se queres uma vida, é preciso que a roubes". 49

A impressão que se tem, depois da leitura de sua obra, é de uma mulher que viveu quinhentos anos em setenta e três. Nin costumava dizer que mais coisas aconteciam com ela do que com mil mulheres juntas e que a palavra infidelidade é oca de sentido para aqueles que têm o corpo inundado de energia amorosa. É nesse movimento de expansão contínua que Nin cria espaço para que outro tipo de sensibilidade floresça. Como Rimbaud, percebeu a urgência na tarefa de reinventar o amor. Em A Spy in the House of Love, a narradora observa: de uma infância, de uma adolescência, de um namoro, de um

\footnotetext{
${ }^{49}$ Ferreira, "Lou Andreas-Salomé: a paixão viva", In: NOVAES. Os sentidos da Paixão, p. 412.
} 
casamento, de uma maturidade, de um envelhecimento, de uma morte, e, então, transmitiam este ciclo monótono aos seus filhos. Todavia, Sabina, estimulada pelos raios lunares, sentia germinar dentro de si o poder de estender o tempo em ramificações de miríades de vidas e amores, de expandir a travessia ao infinito, de pegar desvios imensos e luxuriantes igual a uma cortesã que se torna o receptáculo de múltiplos desejos. As sementes de muitas vidas, de lugares, de muitas mulheres dentro de si foram fecundadas pelos raios lunares porque eles se originam em nossa vida noturna sem limites, que percebemos apenas em sonhos. ${ }^{50}$

Nin foi uma escritora totalmente mesmerizada pelos mistérios da subjetividade humana e, para ela, são esses mesmos mistérios que sustentam a vida. $O$ não reconhecimento dessa dimensão enigmática da existência seria sinônimo de morte. A verdade nunca poderia ser dita em poucas palavras e aqueles que simplificam o universo terminam por tolher a expansão de seu sentido. Tanto o "eu" quanto o universo são realidades que estão em constante desdobramento. O chão está sempre se movendo sob os nossos pés. Nin acreditava na ideia de que o "eu" é ilimitado, múltiplo e não passível de definição. Consequentemente, não teve outra escolha senão abandonar a superfície da realidade e mergulhar em águas mais profundas com o intuito de explorar seus múltiplos "eus": as faces contraditórias de si mesma.

Em Nin, fidelidade a uma única faceta do ser seria fatal, pois reduziria sua potencialidade de vir a ser. Diferentes fidelidades, também, poderiam coexistir no relacionamento amoroso. O título de uma das novelas que compõem o romance, Cities of the Interior, é The Four-Chambered Heart, que constitui em si uma metáfora para expressar a ideia de que mais de uma fidelidade pode habitar o coração. E, em relação a essas questões, as palavras de Nietzsche vão ao encontro do pensamento de Nin: "A grandeza do homem é ele ser uma ponte e não uma meta; o que se pode amar no homem é ser ele transição e perdição". 51

A curiosidade de Nin em relação ao mundo psíquico era tamanha que não hesitou em aceitar o convite para fazer parte de um experimento com ácido lisérgico, realizado pelo psiquiatra Dr. Oscar Janiger, em 1955, na Califórnia. O principal

\footnotetext{
${ }^{50}$ Nin, A Spy in the House of Love, p. 390. Everything they did constricted time. They spoke of one birth, one childhood, one adolescence, one romance, one marriage, one maturity, one aging, one death, and then transmitted the monotonous cycle to their children. But Sabina, activated by the moon-rays, felt germinating in her the power to extend time in the ramifications of myriad lives and loves, to expand the journey to infinity, taking immense and luxurious detours as the courtesan depositor of multiple desires. The seeds of many lives, places, of many women in herself were fecundated by the moon-rays because they came from that limiteless night life which we usually perceive only in our dreams

${ }^{51}$ Nietzsche, Assim falou Zaratustra, p. 13.
} 
propósito do experimento era de reunir um grupo de pessoas de diferentes profissões para que pudessem descrever a maneira como o LSD afetava suas mentes e corpos e fazer um relato de suas visões e impressões. Nin era bastante familiarizada com a literatura de Aldous Huxley, principalmente com o livro The Doors of Perception (1954).

Além de Huxley, outro escritor que Nin admirava e que havia publicado livros sobre estados alterados da consciência, era o poeta francês Henri Michaux (1899-1984). O livro, Miseráble Miracle, escrito sob o efeito da mescalina, era um de seus favoritos. O convite para o experimento foi sua chance de, também, explorar a escrita literária sob o viés da alteração da consciência. Infelizmente, é impossível citar, aqui, as cinco páginas que constam no volume $\mathrm{V}$ do diário em que Nin relata essa experiência insólita.

Para o leitor, é surpreendente notar a rapidez com que uma imagem poética substitui a outra. Tudo se dissolve e liquefaz. Nin nada e voa ao mesmo tempo, ora se encontra no fundo do mar, ora no espaço. Todos os objetos ganham vida, todos os seus sentidos se aguçam. $\mathrm{O}$ auge dessa experiência é quando todas as coisas à sua volta viram ouro e o seu próprio corpo, também, se transforma em ouro. Essa transformação é acompanhada de um prazer indescritível, como se Nin houvesse descoberto o segredo alquímico da vida. A intensidade das visões foi tanta que Nin sofreu um esgotamento físico e mental e teve de passar dias em repouso para se recuperar.

A conclusão que tirou dessa experiência foi a de que, em seu caso em particular, todas as imagens e visões que surgiram quando estava sob o efeito do LSD, já se encontravam presentes em sua obra. De uma maneira natural e espontânea, Nin conseguia acessar todas essas imagens no ato da criação poética. Para que entrasse em contato com a esfera do inconsciente não era necessário que fizesse uso de qualquer substância. Nin esclarece que esse conhecimento já estaria impresso na alma de todo poeta.

Outra maneira que Nin encontrou para se aventurar em uma dimensão mais fantástica da realidade foi por meio da mentira. Mas, nesse caso, um tipo de mentira bastante específica. Nin teve que dissociar essa palavra da noção de imoralidade e associá-la à sua necessidade interna de criação. As "mentiras" que criava eram o fio com que costurava suas múltiplas vidas. O termo cunhado por Bergson que Nin não 
cansa de mencionar no diário é mensonge vital, um tipo particular de mentira que gera vida e que tem o intuito de "agasalhar a ilusão".

Nin tinha o dom da ilusão e costumava dizer que não havia nada que faltasse na realidade que uma mentira não desse jeito. A "mentira" foi um dos subterfúgios que encontrou para dar vazão ao seu ímpeto criativo e expandir a realidade. Sem dúvida, esse foi um aspecto de sua personalidade muito mal compreendido e que deu margem a críticas severas, até mesmo, agressivas. Refiro-me, aqui, a certos críticos que insistem em julgar um autor e o conjunto de sua obra a partir de sua perspectiva de mundo.

Em A casa do incesto, a narradora diz: "as mentiras que conto são como vestes de fantasia" ou "as mentiras não penetram minha alma". A mentira era apenas um "manto protetor" contra a exposição, muitas vezes, insuportável à dura face da realidade. Era a fórmula que havia encontrado de acalentar a ilusão. Ao contrário da personagem Sabina / June que se perdia em suas próprias mentiras, Nin "desenrolava o fio de Ariadne para refazer o caminho de volta". Além da ideia de mensonge vital criada por Bergson, o jogo entre a noção de verdade e mentira proposto por Jean Cocteau também lhe serviu de grande inspiração. Por ser "muito nua", a verdade não estimularia e não incitaria a imaginação humana. Aforismos como - "La vérité est trop nue; elle n'excite pas les hommes", 52 e "Je suis un mensonge qui dit la vérité",53 - certamente tiveram um forte impacto no seu modo singular de se expressar artisticamente.

No entanto, ao criar um mundo cujas fronteiras são permeáveis, Nin teve de lidar com inúmeros conflitos de ordem emocional. Precisava de absolvição. E foi na psicanálise, precisamente na figura de Otto Rank, que encontrou um antídoto para aliviar as dores da alma. Como grande estudioso do tema da criação, Rank teve a sensibilidade para compreender que a crise que Nin enfrentava estava relacionada à necessidade interna de criação e não a um distúrbio psicopatológico.

E, em uma das sessões de terapia descrita no volume I do diário, Rank observa: "O que você chama de mentiras são ficções e mitos. A arte de criar um disfarce pode ser tão bela quanto a criação de uma pintura". ${ }^{54}$ Ao ler suas estórias de juventude, Otto Rank notou que Nin iniciava seus textos dizendo que era órfã. Para ele, esse fato, na

\footnotetext{
${ }^{52}$ Citado por Fowlie em Age of Surrealism, p.128.

${ }^{53}$ Ibid, p. 136.

${ }^{54}$ Nin, Diary I, p. 273. What you call your lies are fiction and myths. The art of creating a disguise can be as beautiful as the creation of a painting.
} 
realidade, expressava seu forte desejo de criar a si mesma e, ao mesmo tempo, evidenciava sua recusa em aceitar qualquer influência de seus pais.

A ideia de mobilidade e de multiplicidade do "eu" era o que impulsionava e movia a vida e a arte de Nin. Sobre este tema, cito novamente Álvaro de Campos, que compartilha da mesma sensibilidade da autora ao afirmar: "Quanto mais eu sinta, quanto mais eu sinta como várias pessoas, / Quanto mais personalidade eu tiver, / Quanto mais simultaneamente sentir com todas elas, / Quanto mais unificadamente diverso, dispersadamente atento, / Estiver, sentir, viver, for, / Mais possuirei a existência total do universo". 55

Em uma passagem do volume I do diário, Nin confessa que tinha sentimentos paradoxais em relação à suas múltiplas vidas. Havia dias que considerava essa experiência profundamente singular e rica. Em outros momentos, sua percepção era de que tudo não passava de uma grave doença, uma espécie de câncer que se alastrava. Sabia por certo que a sensação de fragmentação persistia em relação a si mesma e este era o destino de todos aqueles que seguiam seus impulsos: teriam de percorrer, simultaneamente, diversos caminhos.

Além da psicanálise, a escrita foi outra fórmula encontrada por Nin para dar senso de unidade a sua existência. Ao transmutar cada fragmento de seu ser em diferentes estórias e diferentes linhas narrativas, ou seja, ao transmutar suas várias vidas para o plano simbólico, Nin consegue, finalmente, se integrar. "Estórias, estórias, o único encantamento possível, pois quando começamos a ver nosso sofrimento como uma estória, estamos salvos. Ela era o bálsamo dos primitivos, o modo de trazer encantamento a uma vida de terror". 56

A escrita era para Nin um modo poderoso de criar novas realidades, uma forma direta de a imaginação intervir na esfera do real. Em uma passagem do diário Mirage, Nin explica que a cada livro que escrevia novos amigos surgiam, havia abertura para se penetrar em outros mundos e viver outras experiências. A imaginação era responsável por dar vida a personagens que estavam ocultos em regiões obscuras do nosso ser e esses mesmos personagens, como uma espécie de imã, tinham a capacidade de atrair

\footnotetext{
${ }^{55}$ Pessoa, Fernando Pessoa: obra poética, volume único, p. 406.

${ }^{56}$ Nin, Mirages, p. 199. Stories, stories, the only enchantment possible, for when we begin to see our suffering as a story, we are saved. It was the balm of the primitives, the way of bringing enchantment to the life of terror.
} 
pessoas reais. Dizia que Henry Miller só apareceu em sua vida após ter escrito o livro sobre D. H. Lawrence. Este era o seu verdadeiro interesse na escrita: criar vida imediata, no tempo presente. "Não me importo em ter um nome, em constar em bibliotecas, em ser celebrada após minha morte, o que realmente me interessa é criar vida, vida imediata ao meu redor. Não consigo adentrar novas vidas sem meus livros. Eles são meu barco e vela, meu passaporte e mapa, meu compasso e telescópio".57

O universo literário e seus personagens tinham influência direta na forma como Nin compreendia a realidade, eram modelos de uma forma superior de vida que procurava imitar. Por ser a arte uma intensificação da experiência, Nin sabia do perigo que era tentar transpor esse ritmo para a vida cotidiana. No volume I do diário, se pergunta como seria se, todos os dias, pudesse viver uma cena de Dostoevsky. Para Nin, a vida era, em sua essência, um fenômeno estético. Na sua imaginação, ela, Henry Miller e June eram todos personagens saídos de uma obra de Dostoevsky. Henry Miller, muitas vezes se transformava em D. H. Lawrence e Knut Hamsun. June Mansfield era Albertine, personagem de Proust do livro À la recherche du temps perdu.

A vida cotidiana era uma tortura para Nin, pois nutria uma paixão descomunal pelas altitudes, pelo maravilhoso, pelo êxtase. Em uma carta enviada a seu pai, que consta no diário Incest, Nin comenta que a sua busca por equilíbrio estaria infalivelmente fadada ao fracasso, pois havia nascido sob o signo de Santa Teresa e sob os signos de cortesãs depravadas. Oscilaria sempre entre extremos: ora o misticismo celestial, ora o misticismo terrestre. Além de Santa Teresa, Nin menciona nesta mesma carta que, astrologicamente, estava muito próxima de Bergson, George Sand e Rimbaud. É dentro dessa atmosfera de extremos que A casa do incesto foi construída. A personagem narradora transita entre sobretons e semitons. O choque com a realidade tinha o poder de turvar sua visão. Existia sempre uma fenda na realidade que a lançava nas trevas e, após a experiência de trevas, a fuga divina.

O erotismo, a poesia e o sagrado são dimensões que se encontram entrelaçadas na vida e na obra de Nin. Para Octavio Paz, o erotismo é a poesia do corpo e a poesia é o erotismo da linguagem. A imaginação seria responsável por desencadear tanto a ação erótica quanto a ação poética: o sexo se transforma em rito e a linguagem em cadências

\footnotetext{
${ }^{57}$ Nin, Mirages, p. 92. That is not my interest in writing, not to make a name, not to be exposed in libraries, or celebrated after death, but to create life, immediate life around me. I cannot go into new lives without my books. They are my boat and sail, my passport and map, my compass and telescope.
} 
rítmicas e metafóricas. Na imagem poética, realidades opostas se unem e os sons das palavras se acasalam. O erotismo seria uma metáfora da sexualidade animal e a sua finalidade não está, somente, ligada à procriação. Novos sentidos surgem dessa experiência, uma vez que o erotismo pertence à esfera da criação.

Para a mente ocidental, a associação entre a sexualidade e o sublime pode parecer muito estranha, ao contrário do que ocorre no Oriente. Um dos clássicos da literatura indiana do século 12 é o poema, em sânscrito, Gita Govinda, de Jayadeva Goswami, que descreve a paixão do deus hindu Krishna por Radha. O jogo erótico entre os amantes, que acontece às margens do rio Jamuna, é uma forma de comunhão com o sagrado. Em relação a este tema, George Bataille observa: "EM SUA VERDADE FUNDAMENTAL, O EROTISMO É SAGRADO, O EROTISMO É DIVINO. (...) A humanidade profunda só se revela a nós se reconhecemos a unidade do sentimento divino - do estremecimento sagrado - e do erotismo liberado da imagem grosseira imposta pela pudicícia tradicional". 58

George Bataille ainda argumenta que o sentido último do erotismo está ligado à possibilidade de fusão e à dissolução dos limites. No diário Fire, Nin, ao refletir sobre a natureza da sensualidade, compartilha dessa mesma percepção: “As ideias são elementos de separação. A sensualidade é um comunicante. Mundos mentais são mundos que isolam. Em dias sensuais estamos mais próximos de abraçar todas as coisas e todas as pessoas, todos os homens, o mundo e a criação". ${ }^{59} \mathrm{O}$ ser humano, ao colocar toda sua atenção e energia vital apenas em seu desenvolvimento mental, estaria cometendo um grave erro. Sem o contato profundo com as emoções e a sexualidade, a inteligência se tornaria perigosa. Dentre todas as tarefas realizadas pelos homens, a mais importante seria a de explorar sua potência de vida. A abdicação desse exercício significaria uma escolha pela morte. Ao invés de Eros, seria, então, Thanatos o regente de nossos destinos.

Todavia, Nin tinha consciência do sentido trágico presente na sexualidade. No diário Nearer the Moon, de 1937, a autora diz que "tocamos a terra somente através do sexo" e, em sua busca incessante pelo sentimento de paixão, encontrou toda a violência

\footnotetext{
${ }^{58}$ Bataille, $O$ erotismo, p. 330.

${ }^{59}$ Nin, Fire, p. 278. Ideas are a separating element. Sensuality is a communicant. Mental worlds are isolators. Sensual days bring one nearer to embracing all things and everyone, all men, the world, creation.
} 
que acompanha o desejo. Bataille, também, chama a atenção para os elementos "alarmantes" do erotismo: "geralmente, o divino, o sagrado, também são acompanhados de horror. Emana em todo caso do erotismo algo de trágico. (...) O Marquês de Sade exprimiu esse lado da realidade sexual. Quaisquer que sejam os aspectos insustentáveis de sua obra, ele compreendeu que o erotismo - e o horror implicado no fundo do desejo erótico - colocava em questão o homem inteiro". 60

Tanto Nin quanto Lawrence possuíam uma sensibilidade de origem pagã, da qual restaram apenas ecos em nosso mundo cristão. Proclamavam a integração entre mente e corpo, carne e espírito. Queriam que a vida fosse uma celebração das infinitas possibilidades de criação humana. A esfera apolínea deveria, novamente, se unir à esfera dionisíaca, do êxtase e da embriaguez. A mente, a intuição, e a plenitude física teriam de recompor uma unidade. A natureza de Nin era, essencialmente, religiosa, no sentido mais profundo da palavra religião. Em uma passagem do diário Mirages, esclarece que era através da escrita que conseguia alcançar a consciência cósmica dos místicos: o seu "eu" criador era a esfera superior de si mesma que nunca morreria.

Joaquín Nin, irmão de Nin, diz no prefácio do diário de 1927- 1931 que, ainda muito jovem, Nin havia escrito um conto sobre uma mulher de cem faces e, por ter mostrado apenas uma face a cada pessoa, seria necessário cem pessoas diferentes para escrever sua biografia. Conclui o texto dizendo que acreditava ser Nin essa mesma mulher. Além de escritora, Nin possuía outras faces artísticas. Em seu regresso a Paris, no ano 1927, desfruta de uma breve carreira de dançarina flamenca, que foi interrompida por causa de sua frágil saúde. Nin também gostava de desenhar e criar suas próprias roupas. Apesar de ter uma ligação bastante forte com a música e ter vivido em uma casa bastante musical, seu pai e seu irmão eram pianistas e sua mãe cantora de ópera, Nin opta por explorar apenas a musicalidade das palavras.

Outro talento artístico de Nin era a criação de ambientes. A casa onde morou em Louveciennes, nos arredores de Paris, foi apelidada por Henry Miller de laboratório da alma. Ali, cada cômodo havia sido pintado em uma cor diferente com o intuito de evocar uma determinada sensação: “o vermelho para veemência, o turquesa para

\footnotetext{
${ }^{60}$ Bataille, $O$ erotismo, p. 330.
} 
devaneios, cor de pêssego para gentileza, verde para descanso, cinza para escrever a máquina". 61

A experiência estética estava no centro da vida de Nin. Mais do que criar objetos de arte, seu desejo era se tornar uma obra de arte. A estetização da vida seria uma forma de redimir a nossa condição humana de desamparados, uma tentativa de reverter a nossa queda no tempo. Nin construiu um mundo próprio para que pudesse habitar, um mundo que acolhesse sua sensibilidade artística e os anseios da alma.

Blake defendia a ideia de que o gênio não pertence à sua época: "Todas as épocas são semelhantes, mas o gênio está sempre acima de sua época". ${ }^{62}$ Nin se sentia completamente alheia a seu tempo. Seu instinto de proteção e o cuidado que dispensava a outras pessoas eram o que a mantinha presa à vida, caso contrário, esclarece que sua vontade seria de viver intensamente em alguns poucos anos e em seguida morrer, da mesma maneira que Rimbaud e muitos dos místicos.

Nin não se sentia, emocionalmente, ligada a nenhum país. Devido à profissão de seu pai, aos onze anos já havia morado em onze países diferentes. Em sua casa falava-se o espanhol e o francês. Somente aos treze anos é introduzida ao inglês e aos dezessete decide que essa seria sua língua literária. Um aspecto curioso da sua personalidade é que falava todas as línguas com sotaque. Qual seriam, então, a sua terra natal e a sua língua materna? Uma forte sensação de exílio acompanhou Nin durante toda sua vida. No entanto, a minha intuição é de que Nin habitava "As cidades da subjetividade", uma tradução livre do título do livro Cities of the Interior, e sua língua materna é a língua dos símbolos.

Nin não foi escritora engajada, não fez parte de nenhum movimento de cunho ideológico como o marxismo ou o feminismo, mas nem por isso deixou de ser uma escritora sensível às questões da mulher. Por esta razão, a escritora feminista americana, Kate Millett, escreveu um artigo, em 1976, intitulado "Anaïs: A Mother to us All”. A maneira como Nin aborda "o feminismo" está muito mais centrado no aspecto psicológico do que no aspecto político-ideológico.

\footnotetext{
${ }^{61}$ Nin, Diary Volume I, p. 5. (...) lacquer red for vehemence, pale turquoise for reveries, peach color for gentleness, green for repose, grey for work at the typewriter.

${ }^{62}$ Citado por Bloom em Genius: A Mosaic of One Hundred Exemplary Creative Minds, p. 10.
} 
No seu modo de compreensão, as mudanças mais significativas da humanidade viriam do conhecimento e do fortalecimento do mundo subjetivo. Aquele que teve a coragem de assumir total responsabilidade por seu crescimento, que ampliou sua visão, que refinou sua capacidade de expressão, é um ser liberado, e somente quando o ser manifesta tais qualidades é que ele tem o poder de influenciar, de maneira positiva, a esfera coletiva.

Por sua vez, a coletividade composta apenas por pessoas que não se submeteram a esse processo é uma coletividade agonizante que embrutece a experiência humana. $\mathrm{O}$ grupo, ao buscar uma única fórmula para resolver todos os problemas, inibe o crescimento individual. A ação por si só e os slogans políticos não têm o poder de alterar a realidade. A principal razão pela qual os diários de Nin foram tão aclamados, na década de 60 , é por terem contribuído enormemente para a liberação da mulher em uma camada mais profunda da consciência.

Henry Miller, no ensaio Un etre etoilique, ${ }^{63}$ afirma que a escrita de Nin se sobressai por ser, de fato, uma escrita feminina, no sentido de que ela recria o mundo a partir de uma outra lógica inteiramente diferente da lógica fabricada que prevalece no universo da cultura. Essa outra lógica dá luz a uma linguagem ultramoderna que consegue ser, ao mesmo tempo, precisa, obscura e labiríntica, pois só a união desses elementos opostos seria capaz de captar a trama psicológica do universo feminino. Em Nin, a noção de criação feminina está muito mais próxima ao projeto artístico proposto pelo movimento Surrealista do que de um discurso feminista.

\begin{abstract}
A mulher deve criar dentro do mistério, das tempestades, dos terrores, dos infernos do sexo, da batalha contra as abstrações e a arte (...). A arte deve ser para ela algo semelhante a um ritual antigo e pessoal onde cada pensamento espiritual torna-se visível, encenado e representado. (...) Tragédias, conflitos, mistérios são pessoais. O homem fabricou uma espécie de separação que é fatal. A mulher não deve fabricar. Ela precisa descer até o verdadeiro útero e expor seus verdadeiros segredos e seus labirintos. Acredito, em certos momentos, que o homem criou a arte por medo de explorar a mulher. Acredito que a mulher fica balbuciando por medo de dizer o que tem para dizer (...). Mas a mulher não é apenas a natureza. Ela é a sereia com a cauda mergulhada no inconsciente. ${ }^{64}$
\end{abstract}

\footnotetext{
${ }^{63}$ Miller,’Un Etre Etoilique”, In: JASON, Philip K (Ed.). The Critical Response to Anaïs Nin, p.153.

${ }^{64}$ Nin, Diary II, p. 235. Woman has to create within the mystery, storms, terrors, the infernos of sex, the battle against abstractions and art (...). Art must be for woman, more like a personified ancient ritual, where every spiritual thought was made visible, enacted, represented. (...) Tragedies, conflicts, mysteries are personal. Man fabricated a detachment which became fatal. Woman must not fabricate. She must descent into the real womb and expose its real secrets and its labyrinths. I believe at times that man created art out of fear of exploring woman. I believe woman stuttered about herself out of fear of what
} 
Em todas as épocas existiram mulheres que se dedicaram à escrita literária. Nin era admiradora de Lady Murasaki, uma japonesa nascida no ano 900, que escreveu diários poéticos-eróticos. As escritoras francesas de diversas épocas como Ninon de Lenclos (1620-1705), George Sand (1804-76) e Colette (1873-1954) também foram fontes de inspiração. O livro Nightwood (1936), da escritora americana Djuna Barnes, marcou profundamente a trajetória de Nin. O impacto dessa obra foi tão avassalador que ela criou uma personagem chamada Djuna, como uma espécie de tributo à escritora.

Lou Andreas-Salomé, a musa inspiradora de Freud, Rilke e Nietzsche, foi a grande heroína de Nin. Salomé escreveu livros de ficção e ensaios que refletiam sobre a condição da mulher, a natureza de Eros e dos relacionamentos amorosos. Para ela, "o mundo da criação e do amor significa: volta ao país natal, entrada no paraíso; o da impossibilidade de criar, ou do amor morto, é, ao contrário, um exílio onde os deuses nos abandonam". ${ }^{65}$ Nas cartas trocadas entre Freud e Salomé, nos primórdios da psicanálise, é possível perceber o respeito que Freud tinha por suas ideias.

Salomé também inspirou Nietzsche a escrever Assim falou Zaratustra e, para ele, ela foi a única pessoa que realmente havia compreendido sua obra. O poeta Rilke dedicou a ela vários poemas amorosos. O poder de seu espírito criador contagiava todos aqueles que cruzavam seu caminho e logo se sentiam, também, impelidos a criar. No ensaio "Lou Andreas-Salomé: a paixão viva", ${ }^{66}$ Luzilá Gonçalves Ferreira diz que quando Salomé se apaixonava por um homem, nove meses depois, este homem dava à luz um livro.

O livro Wilder Shores of Love (1954), de Lesley Blanch, em particular, exerceu forte fascínio na imaginação de Nin. Esta obra é uma biografia de quatro mulheres que abandonaram a Europa do século 19 para viver uma vida de aventuras no Oriente. As quatro protagonistas ousaram dizer não ao estilo de vida convencional e puritano de sua época e, assim, deram outro curso para seus destinos.

she had to say (...). But woman is not nature only. She is the mermaid with her fish-tail dipped in the unconscious.

${ }^{65}$ Ferreira, “Lou Andreas-Salomé: a paixão viva”, In: NOVAES. Os sentidos da paixão, p. 410.

${ }^{66}$ Ibid, p. 419. 


\title{
1.1 - DIÁRIO VERSUS FICÇÃO
}

A obra ficcional de Nin foi sendo criada paralelamente à escrita de seu diário. $\mathrm{Na}$ verdade, estas duas dimensões da criação literária se interpenetram e uma se alimenta da outra. Ao mesmo tempo em que Nin retira elementos do diário para compor sua obra ficcional, também reflete e comenta as etapas de seu processo criativo nas páginas do diário. Uma das grandes estudiosas da obra de Nin, Suzanne Nalbantian, se refere ao seu modo de criação e à sua estética como estética da transmutação: da vida para o diário, do diário para a ficção e da ficção novamente para o diário. A impressão que se tem ao ler o conjunto de sua obra é a de que esses vários planos são peças de um enorme quebra-cabeça e que, aos poucos, vão compondo uma unidade, dando origem a um único livro. Nalbantian afirma:

\begin{abstract}
O processo de ficcionalização de Anaïs Nin envolve a recomposição e a recriação de fatos relacionados a lugares e pessoas da sua vida cotidiana. Sua estética era a estética da transmutação que via a arte como um processo alquímico. Em vez de rejeitar a esfera pessoal, como queriam alguns escritores, a autora a coloca em local de destaque, já que sua arte partia da experiência do mundo para os diários e dos diários para a ficção. ${ }^{67}$
\end{abstract}

Cabe esclarecer que a obra ficcional de Nin não é mera colagem de trechos retirados do diário. Há um trabalho de recriação de linguagem. O grande objetivo da autora ao escrever ficção era pôr em cena elementos míticos e arquetípicos. Para isso, Nin teve de desenvolver uma linguagem altamente simbólica cujas características principais são a condensação, o deslocamento e a elipse:

\begin{abstract}
Eu escrevo como poeta dentro da estrutura da prosa. Seleciono partes do mundo exterior que revelam o mundo interno, partes que são necessárias no drama interior. Isso é o que está por trás dos meus personagens ou descrições de lugares aparentemente incompletos. A casa toda, o corpo todo ou o local todo podem não estar lá, mas nós sabemos da pintura moderna que uma coluna pode significar mais do que a casa toda e, como na escultura de Brancusi, a expressão do vôo de um pássaro foi alcançada pela eliminação das asas. ${ }^{68}$
\end{abstract}

\footnotetext{
${ }^{67}$ Nalbantian, "Into the House of Myth". In: STUHLMANN. Anaïs International Journal Volume 11, p. 12. Anaïs Nin's process of fictionalization involved the recomposition and recreation of facts regarding place and person that she had culled from her quotidian life. Hers was an aesthetics of transmutation which saw art as alchemic. Rather than reject the personal as previous writers did, she heightened it for her art as she moved from her life experience to diaries and on to her fiction.

${ }^{68}$ Nin, The Novel of the Future, p. 24. I write as a poet in the framework of prose. I select parts of the external world which reveal the internal, the parts which are necessary to the inner drama. That is what lies behind my seemingly incomplete characters or descriptions of places. The whole house or the whole body or the entire environment may not be there, but we know from modern painting that a column can
} 
Em contraponto à ficção, o diário foi concebido como uma obra aberta, um organismo vivo a fluir em uníssono com a vida e com o tempo, a sofrer constantes transformações e ampliações. Era o espaço privilegiado onde o instante deveria ser apreendido e destilado no calor da hora, para que mais tarde fosse possível reviver a experiência do mundo. Nin sabia o quanto a memória era traiçoeira e por isso desejava capturar tudo o que o momento presente evocava. Quanto ao propósito da escrita do diário, a autora explica:

\begin{abstract}
A preocupação do romancista: como capturar o momento vivo, a resposta veio do diário. Escreva enquanto ele ainda está vivo. Não o deixe curtido em álcool até você achar que está pronto para escrever. Descobri através do diário, inúmeros elementos essenciais para a vitalidade da escrita. Dentre os quais, os mais importantes são a naturalidade e a espontaneidade [...]. Este entusiasmo gera uma vitalidade que quase sempre fenece em uma obra formal. Improvisação, associação livre de imagens e ideias, obediência a certos estados de espírito, impulsos, tudo isso tem muito a acrescentar. O diário, ao lidar apenas com o instante, com a matéria viva, com o que está próximo, escrito no calor da hora, desenvolveu uma empatia com o presente. ${ }^{69}$
\end{abstract}

De acordo com Henry Miller, ${ }^{70}$ o diário de Nin situa-se ao lado de obras de autores como St. Augustine, Petronius, Abélard, Rosseau e Proust. O diário é um gênero literário como o romance e a peça de teatro, com a ressalva de que ele requer uma tela bem mais ampla, daí sua natureza épica. Ele é uma espécie de autobiografia ficcional em que o autor se insere dentro da própria obra e se transforma em personagem, ou seja, em um duplo de si mesmo. O aspecto artístico mais significativo do diário é o de criar a ilusão de que estamos em contato direto com a alma do autor. Miller chama a atenção para o fato da literatura, em nossa época, estar mais próxima de materiais biográficos, relatos humanos, fragmentos, notas, diários. $\mathrm{O}$ escritor sente que determinadas formas literárias foram repetidas à exaustão e se tornaram rígidas, mortas, por isso perderam a capacidade de comunicar a experiência humana.

signify more than a whole house, and as in Brancusi's sculpture, the expression of the flight of a bird was achieved by eliminating the wings.

${ }^{69}$ Nin, The Novel of the Future, p. 160. The preoccupation of the novelist: How to capture the living moments, was answered by the diary. You write while they are alive. You do nor preserve them in alcohol until the moment you are ready to write about them. I discovered through the diary several basic elements essential to the vitality of writing. Of these the most important are naturalness and spontaneity [...]. This enthusiasm produced a vividness which often withered in the formal work. Improvisation, free association of images and ideas, obedience to mood, impulses, brought forth countless riches. The diary, dealing only with the immediate, the warm, the near, being written at white heat, develop a love of the living moment.

${ }^{70}$ Miller,’Un Etre Etoilique”, In: JASON, Philip K (Ed.). The Critical Response to Anaïs Nin, p.147. 
O modo que o artista encontra para compensar a falta de criatividade de seu tempo é redescobrir em si mesmo a fonte eterna da criação. Sua obsessão se torna a de investigar os mistérios da personalidade. O diário é um espelho do labirinto da alma, uma viagem mitológica e metamórfica: de mortes, renascimentos e inúmeras provações. O Minotauro precisa ser morto para que o herói retorne à vida com sua capacidade visionária ampliada. No caso de Nin, ela opta por seduzir o Minotauro, não por assassiná-lo e, por isso um de seus romances chama-se Seduction of the Minotaur. Em sua obra, Nin explora todas as formas possíveis de encantamento.

Uma de suas palavras prediletas é ensourcell, que vem do francês sorcier, que dá origem à palavra sorcerer no inglês, e significa feiticeiro. Ensourcell seria, então, a capacidade de encantar, enfeitiçar. A arte de Nin está em sintonia com a arte feita no Oriente Médio, segundo a qual o principal atributo estético que se espera do artista é o de que manifeste o tarab. Não há uma palavra em português que consiga traduzir todos os sentidos contidos na palavra árabe tarab. Ela significa, ao mesmo tempo, poder de encantamento, de conduzir as pessoas a um estado de êxtase, transe, euforia, tristeza, alegria. Sua função seria a de estimular sensorialmente aqueles que entram em contato com a música, a dança, a palavra poética: a plateia vivencia, de maneira profunda, diferentes realidades emocionais em uma atmosfera em que a sensação de tempo é abolida.

Marcel Proust foi uma referência marcante para Nin e lhe serviu de exemplo na escrita do diário. Inúmeros são os comentários e reflexões que a autora tece sobre o romance À la recherche du temps perdu. Para ela, tanto o diário quanto a obra de Proust abarcam um espaço de tempo bem mais amplo, o que torna possível acompanhar a trajetória dos personagens e suas transformações. Nesse sentido, ambos os autores são inovadores e experimentais, pois rompem com as estruturas do romance convencional. No volume V do diário, Nin diz: "Não há separação entre a minha vida e a minha arte, minha obra. Recuso modelos artificiais. Estórias nunca terminam. Um ponto de vista muda a cada momento. A realidade muda, é relativa". ${ }^{71} \mathrm{O}$ diário é uma obra inacabada, um eterno work in progress, pois não é sua finalidade chegar a um desfecho. Ele se destina a criar a ilusão de um movimento perpétuo:

\footnotetext{
${ }^{71}$ Nin, Diary $V$, p. 52. There is no separation between my life and my craft, my work. I refuse artificial patterns. Stories do not end. A point of view changes every moment. Reality changes. It is relative.
} 
As limitações do romance me fizeram voltar à escrita do diário. Por exemplo, quando eu terminei o romance Winter of Artifice, eu senti que a relação entre o pai e a filha não havia terminado, porque no diário eu tinha o exemplo de uma relação contínua que não tinha um fim, mas que se modificava. Talvez um romancista possa sentir que não tenha mais nada a acrescentar ao personagem ao fim de um romance. Esse não era o meu caso. A continuidade das relações e suas modificações, como em Proust, me fizeram sentir que havia uma outra verdade a ser explorada, que haveria sempre uma outra revelação, uma outra descoberta sobre meu pai. A ideia de que esse tema pudesse ser esgotado nem sequer me ocorreu, porque eu podia ver a sua continuidade nas páginas infindas do diário. O diário me deu uma consciência de movimento perpétuo e orgânico, mudanças perpétuas na personalidade. Ao escrever um romance ou um conto o movimento está aprisionado no espaço de tempo da estória. Há algo de estático nisso. Proust me pareceu o único escritor que tinha fluxo e continuidade infinita. $^{72}$

Em The Novel of the Future, Nin esclarece a razão pela qual não havia se tornado apenas escritora de diários e comenta que sempre se sentiu impelida a explorar outras linguagens e outras formas de manifestações artísticas:

Porque não me dediquei apenas à escrita de diários? Por que havia outro mundo além do universo pessoal que poderia ser abordado por meio de uma forma artística, por meio da ficção. Por que não permaneci dentro das fronteiras de House of Inceste e escrevi apenas poemas em prosa, material onírico, tal como Les chant de maldoror? Por que a minha motivação era colocar em prática a ideia de Jung: proceda do sonho para o real. Para mim, isso significava relacionar o sonho à vida, o mundo interno ao externo, as partes secretas e a persona do ser. A aparência e a realidade, a ilusão e a realidade. Sem o diário, o poema em prosa e a ficção eu não teria criado a relação entre eles. É essa relação que me interessa, a conexão, as pontes de contato, a interação, a dinâmica que rege as relações entre os seres humanos e, também, entre as formas que os seres humanos usam para se expressarem. ${ }^{73}$

\footnotetext{
${ }^{72}$ Nin, The Novel of the Future, p. 161. The limitations of the novel sent me back to the diary. For example, when I finished the novel Winter of Artifice, I did not feel that I had finished with the relationship of father and daughter, because in the diary I had an example of a continuum which did not come to an end but which changed. Perhaps a novelist is through with a character when he is finished with his novel. I was not. The continuity of relationship and its alterations, as in Proust, made me feel there was always another truth around the corner, there would always be another revelation, another discovery about my father. The concept that this theme was completed would never even have occurred to me, because I could see its continuation in the endless diary. The diary made me aware of organic and perpetual motion, perpetual change in character. When you write a novel or a short story, you are arresting motion for a period of that story, a span of time. There is something static about that. Proust seemed to me the only writer who had flow and infinite continuum.

${ }^{73}$ Ibid, p. 161. Why I did not remain merely a diarist? Because there was a world beyond the personal which could be handled through the art form, through fiction. Why did I not stay within House of Incest and write only prose poems, dreamed material, such as Les chants de maldoror? Because my drive was stated by Jung: proceed from the dream outward. I took this as relating dream and life, internal and external worlds, the secrets and persona of the self. Appearance and reality, illusion and reality. Without the diary, the prose poem, and the fiction I could not have achieved the relation between them. It is the relation which interested me, the connection, the bridges, the interaction, the dynamics of relation among human beings as well as among the ways of expression human beings use.
} 
Entretanto, outro motivo pelo qual Nin se dedicou a escrever obras de ficção foi sua recusa em publicar o diário original. Não era seu desejo expor sua vida e as vidas de várias outras pessoas. O diário original não poderia ser publicado. Havia muitos segredos em suas páginas que não poderiam ser revelados. Por isso, Nin esclarece, no poema A casa do incesto, que a única coisa que lhe restava era dizer "a verdade disfarçada num conto de fadas". Ao mencionar "contos de fadas", Nin está se referindo à sua escrita ficcional: "Mais páginas são acrescentadas ao livro, páginas que lembram o vaivém de um prisioneiro no espaço a ele destinado. E a mim, o que foi predestinado dizer? Apenas a verdade disfarçada num conto de fadas, e é por trás deste conto de fadas que todas as verdades espiam, como se estivessem detrás das grades das janelas de uma mesquita". 74

$\mathrm{O}$ aspecto mais significativo da personagem narradora de $A$ casa do incesto é o de que ela é escritora e está escrevendo um livro enquanto vive suas experiências rumo à casa do incesto. Em uma passagem, observa: "Adentrei meu livro em busca de paz". 75 No entanto, sabemos que esta procura está fadada ao fracasso. A verdade, em seu estado original, nunca poderá ser dita. A verdade sem disfarces seria letal, por isso o desejo de contá-la e recontá-la em diferentes versões. "À medida que adentro o livro, sou cortada por cacos de vidro e garrafas quebradas onde ainda persiste o cheiro de esperma e perfume". ${ }^{76}$ Em A casa do incesto, o processo de escrita está entrelaçado com a dor: as palavras abrem feridas na carne e a sensação de angústia acompanha a narradora durante toda sua trajetória.

O conjunto da obra literária de Nin foi criado de maneira análoga à exploração e à expansão de seus múltiplos "eus". O diário original é a matriz onde surgem os duplos: o diário ficcionalizado e a escrita ficcional. Para o crítico Jean Owen, ${ }^{77}$ o leitor, à medida que avança na leitura da obra de Nin, é tomado por uma sensação de déjà vu. As mesmas estórias vão sendo contadas várias vezes, com a ressalva de que são narradas de formas diferentes. Nin "brinca" com os gêneros literários, ora oculta, ora revela fatos.

\footnotetext{
${ }^{74} \mathrm{Nin}$, House of Incest, p. 43- 46. More pages added to the book but pages like a prisoner's walking back and forth over the space allotted him. What is it allotted me to say? Only the truth disguised in a fairytale, and it is the fairytale behind which all the truths are staring as behind grilled mosque windows.

${ }^{75}$ Ibid, p. 43. I walked into my own book, seeking peace.

${ }^{76}$ Ibid, p. 43. As I move within my book I am cut by pointed glass and broken bottles in which there is the odor of sperm and perfume.

${ }_{77}$ Owen, "Uncanny Echoes: Anaïs Nin Narrative of Incest". In: HERRON, Paul. A Café in Space: The Anaïs Nin Literary Journal Volume 11, p. 41.
} 
Sua literatura é, ao mesmo tempo, jogo e risco e Nin tem o conhecimento pleno de como manipular as peças desse jogo.

O sentido da palavra unheimlich, discutido por Freud no ensaio Das Unheimlich caracteriza, de forma precisa, o sentimento que persegue o leitor ao entrar em contato com a obra de Nin: estranha familiaridade. Nin escrevia e reescrevia compulsivamente, e foi dentro desse movimento que os duplos foram concebidos. $\mathrm{O}$ diário Incest se destaca por dar origem a várias outras estórias, como, por exemplo, o primeiro volume do diário ficcionalizado, o poema A casa do incesto, a novela Winter of Artifice (1939), o livro de contos Under a Glass Bell (1944) e o capítulo "Bread and the Wafer" da novela Ladders to Fire (1959). É importante ressaltar que a segunda edição de A casa do incesto e Winter of Artifice, publicada nos Estados Unidos, na década de 40 e 50, respectivamente, sofreu modificações.

No caso específico de A casa do incesto, ao ler um ensaio crítico de Henry Miller sobre o poema, notei que ele citava trechos do livro que não correspondiam à edição da década de 50, na qual minha pesquisa se baseia. Infelizmente, não consegui obter informações mais precisas que confirmassem se, de fato, partes do texto haviam sido reescritas ou não, até mesmo porque a primeira edição do poema nunca foi reeditada. Outro dado relevante é o de que, na última edição de A casa do incesto, Nin incluiu nove fotomontagens, em um estilo surrealista, criadas pelo artista russo Val Telberg. As fotomontagens consistem em uma justaposição de várias imagens - de corpos, do mar, de espelhos, de água - que compartilham da mesma natureza poética do texto de Nin.

Em relação ao livro Winter of Artifice, em 2007, foi publicado uma edição facsímile do original de 1939, o que possibilitou a comparação entre as duas edições. Do meu ponto de vista, as alterações foram tão drásticas, que arrisco dizer que são duas obras diferentes, ou melhor, a versão de 1945 é um duplo de um outro duplo. A edição orginal de Winter of Artifice, de 1939, é composta por três estórias. A primeira chamase "Djuna" e gira em torno dos personagens Djuna, Hans e Johanna, baseados nos personagens do diário Anaïs Nin, Henry Miller e June Mansfield. A segunda é intitulada "Lilith", em que a personagem principal Lilith reencontra seu pai após 20 anos. Nessa estória, Nin reconta, em uma linguagem altamente poética e velada, o mesmo episódio narrado, em detalhes, no diário Incest sobre o reencontro com seu pai e o 
relacionamento amoroso que tiveram. Nin, também, se refere a esta estória como Don Juan and his Daughter, The Father Story e The Double nas páginas do diário. A última estória chama-se "The Voice", em que as duas personagens principais das estórias anteriores, Djuna e Lilith, se encontram no "Hotel Chaotica" para sessões de terapia com o personagem chamado "The Voice", espécie de oráculo e claramente uma referência ao psicanalista Otto Rank.

Já na versão de Winter of Artifice, de 1945, Nin substitui a primeira estória "Djuna" por outra, inteiramente diferente, chamada "Stella". A segunda estória tem o título modificado de "Lilith" para "Winter of Artifice". Aqui, o texto permanece o mesmo só que, ao contrário da primeira edição, em que a narrativa era feita em primeira pessoa, na segunda edição, o texto é narrado em terceira pessoa. A última estória, "The Voice", sofreu alterações significativas, apesar de Nin ter mantido o mesmo título.

Nin foi uma autora bastante sensível às críticas que, por ventura, eram feitas à sua obra e, mesmo críticas vindas de pessoas que lhe eram próximas, como seu marido e Henry Miller, tinham o poder de abalar sua estrutura emocional e lhe causavam grande sofrimento. Sempre reagia de maneira extrema a qualquer tipo de sugestão. No entanto, a própria Nin fez duras críticas à sua obra ficcional e dizia que nunca teria coragem de incluir trechos de sua ficção nas páginas do diário, ao passo que partes do diário, certamente, poderiam constar em suas estórias.

Em uma carta enviada ao pai, em 1933, Nin esclarece que faltava à sua ficção a mesma vivacidade e originalidade contidas no diário, e que uma única página do diário causava mais arroubo no leitor do que páginas e páginas da ficção. Nessa mesma carta, Nin diz em relação ao diário: "De tempos em tempos eu sinto vontade de publicá-lo anonimamente - tal como ele é, demasiadamente humano, simples e direto, como o resultado de um esforço sobre-humano de equilibrar as mentiras dos contos de fadas que eu achei que deveria dar ao mundo. Foi uma péssima ideia ter nos educado com contos de fada. Eu tentei fazer com que eles se tornassem realidade para as pessoas, e isso é perigoso, você acaba perdendo sua própria alma". ${ }^{78}$

\footnotetext{
${ }^{78}$ Nin, Incest, p. 237. So from time to time I feel like releasing it - anonymously - just as it is, terribly human, simple and direct, as a superhuman effort to balance the lies in the fairy stories that I thought I should give the world. It was wrong to bring us up on fairy stories. I have tried to make them come true for others, and that's dangerous. One loses one's own soul.
} 


\title{
1.2 - A ARTE TOTAL
}

A prosa poética de Nin destaca-se, sobretudo, pela cadência, musicalidade e ritmo que envolvem as palavras. Uma de suas aspirações era de que sua escrita tivesse um efeito direto nos sentidos do leitor, que pudesse evocar inúmeras sensações em uma atmosfera de total arrebatamento, da mesma maneira que acontece quando escutamos uma música ou vemos uma pintura. É importante mencionar que Nin escrevia diariamente, como um pianista que estuda escalas para manter a técnica:

\begin{abstract}
Existe uma forma de escrita que é semelhante à arte musical. Afeta diretamente os nossos sentidos sem primeiro apelar para o nosso intelecto, sem passar por um processo analítico ou consciente. Nesse sentido, ela age de modo parecido às nossas experiências de vida, que entram diretamente em nosso corpo antes de sermos capazes de dissecá-las. 79
\end{abstract}

Na concepção de Nin, todas as formas de expressão artística estão interligadas. A dança, a música, as artes plásticas, a literatura seriam diferentes manifestações de um mesmo princípio criador, de uma única linguagem universal. No diário Mirages (2013), Nin observa:

\begin{abstract}
Será que vou ser o músico da literatura, será que irei improvisar, será que as palavras emitirão sons, será que elas irão ressoar e ressoar? Será que vou ser a dançarina da literatura, usar as palavras mais leves? Será que elas dançarão sozinhas, um balé mesmo nos momentos mais trágicos? Será que serei a atriz da literatura, usar todas as máscaras, representar todos os papéis? ${ }^{80}$
\end{abstract}

Ao ler a primeira versão de A casa do incesto, Henry Miller disse, em uma carta enviada para Nin, ${ }^{81}$ que escutava em sua escrita composições de Chopin, Stravinsky, Leo Ornstein, Debussy, Richard Strauss e via quadros de Goya e Felicien Rops. Na arte moderna, vários foram os artistas que buscaram essa comunhão entre as artes e suas diferentes linguagens: Franz Liszt foi fortemente influenciado por Raphael e Michelangelo; Debussy por Turner, Monet e Mallarmé, mais especificamente pelo

\footnotetext{
${ }^{79}$ Ibid, p. 175. There is a form of writing which is like the art of music. It can affect us through the senses directly without first appealing to the intellect, without going through an analytical or conscious process. In this, it acts more like our life experiences, which enters the body directly before we are able to dissect them.

${ }^{80}$ Nin, Mirages, p. 146. Will I be the musician of literature, will I improvise, will the words emit a sound, will they resound and resound? Will I be the dancer of literature, use the lightest words? Will they dance alone, a ballet even in the most tragic moments? Will I be the actress of literature, wear all the masks, play all the roles myself?

${ }^{81}$ Miller, “About the Mona Pages”. In: STUHLMANN. Anaïs International Journal Volume 6, p. 94.
} 
poema L'Aprés-midi d'un faune; Paul Klee pela música polifônica; Kandinsky por Schoenberg; Rimbaud inventou as cores das vogais; Baudelaire, no poema "Correspondências" exaltou a comunicação entre os sentidos; Mallarmé e Yeats renderam-se à magia da dançarina Loie Fuller, ${ }^{82}$ precursora da dança moderna, e a ela dedicaram ensaios e poemas. Mallarmé dizia que as performances de Loie Fuller eram uma forma teatral de poesia, a poesia encarnada em um corpo em movimento. $\mathrm{O}$ seu grande desejo de poeta era o de que suas palavras pudessem conter todas as qualidades que apreciava em Fuller: luz, leveza, cor, movimento e som.

Sinestesia seria um outro nome para essa noção de correspondências entre as linguagens artísticas. É importante ressaltar que ela não é somente um atributo da arte moderna. Na realidade, este é um fenômeno que acompanha a humanidade desde os seus primórdios. Os xamãs, em seus rituais de cura, utilizam-se da música, da dança, do som do tambor para alterar o seu estado de consciência e gerar êxtase. É por meio do êxtase que eles têm acesso a outras dimensões. Nesse estado de consciência, os sentidos se ampliam e se comunicam: a música não é percebida somente por meio da audição, mas, também pela visão. A música se transforma em figuras geométricas e essas mesmas formas auxiliam o xamã na cura de doenças. Em várias etnias, a música visual está na própria base dos desenhos artísticos que ornamentam tecidos e cerâmicas. E não é uma experiência incomum, para os membros desses grupos, olhar para estas formas e ouvir música.

Dentre os artistas mencionados anteriormente, Wassily Kandinsky se destaca por ter criado um universo artístico bastante análogo ao de Nin. A intenção da autora era de libertar as palavras da tarefa de representar o mundo visível para que elas pudessem transcriar a realidade. Esse foi exatamente o projeto artístico desenvolvido por Kandinsky, com a única diferença de que, ao invés de palavras, sua intenção era de libertar formas e cores de sua obrigação na representação do mundo externo. Nesse sentido, ele foi um dos grandes revolucionários da pintura. Tal como Nin, Kandinsky deixou inúmeros textos em que refle sobre o processo criativo e sua poética.

O livro Concerning the Spiritual in Art (Du Spirituel dans L'art 1912), foi concebido como uma espécie de teoria da harmonia na pintura. Para Kandinsky, cada cor e cada forma possuem qualidades espirituais diferentes que ressoam de maneira

\footnotetext{
${ }^{82}$ Ver Loie Fuller: https://www.youtube.com/watch?v=YNZ4WCFJGPc
} 
poderosa na alma humana. O pintor desenvolveu seu próprio método em que formas e cores se fundem para criar uma espécie de acorde musical que teriam um impacto direto na sensibilidade do espectador. Alguns de seus quadros deveriam ser vistos/escutados como peças musicais. Dentre todas as linguagens artísticas, o pintor tinha um gosto especial pela música por ser ela uma arte liberta da tarefa de representar a realidade.

Para Kandinsky, a união entre cores e formas deveria surgir de uma necessidade interna do artista em uma atmosfera enigmática e mística. As emoções assumiriam um papel preponderante na criação, pois elas é que dariam alma à pintura. Nin também acreditava que a fonte da criação está no universo emocional do artista e, para ela, o escritor escreve com o corpo, não com tinta e papel. Caso sua capacidade de ver, de ouvir, de sentir esteja atrofiada, melhor é que desista da escrita. Assim como Nin, Kandinsky também foi um artista múltiplo e tinha interesses em diferentes áreas. Escreveu poemas, se interessou pela doutrina Teosófica, foi um profundo estudioso do folclore russo e das práticas espirituais dos xamãs da Sibéria. Todo esse conhecimento foi incorporado à sua arte. Para ele, o artista era uma espécie de xamã: sua missão era de regenerar o mundo da cultura e ampliar a capacidade das pessoas de terem experiências reais. A verdadeira arte seria um ritual mágico que teria o poder de despertar a força visionária e profética da consciência humana.

\section{3 - REALISMO VERSUS REALIDADE}

O Realismo na literatura foi o principal alvo de críticas de Nin, tanto na sua concepção estética quanto na sua base ideológica. Para a autora, o romance realista, em busca de objetividade e verossimilhança, apenas refletia, como um espelho, as "aparências", as "máscaras" e a "superficialidade" da realidade em detrimento da riqueza e complexidade da "verdadeira" vida. Em termos ideológicos, a vertente realista nega a dimensão metafísica da existência, uma vez que sua visão do ser humano está baseada em determinismos e condicionamentos sociais. "Para encontrar a realidade é preciso descartar o realismo", 83 afirma Nin.

\footnotetext{
${ }^{83}$ Ibid, p. 3. One could only find reality by discarding realism.
} 
Além disso, Nin não achava a palavra "realismo" adequada quando utilizada para fins estéticos, e sempre gostava de citar uma frase em que Federico Fellini (192993) dizia: "Realismo não é uma boa palavra. Em certo sentido tudo é real. Não vejo nenhuma separação entre o imaginário e o real. Vejo muita realidade na imaginação". ${ }^{84}$ Evelyn J. Hinz, em The Mirror and the Garden (1973), faz a seguinte observação sobre as objeções de Nin a respeito da estética realista:

\begin{abstract}
Em sua objeção aos realistas, é bastante óbvia a razão pela qual Nin achava que o espelho realista não transmitia o real, mas era o símbolo perfeito da não realidade e da refração. $\mathrm{O}$ espelho reflete apenas o exterior, a máscara, e não a essência do homem. Nesse sentido, o artista que registra esse reflexo é apenas um historiador, nunca um profeta, pois tudo que ele vê diz respeito ao que já aconteceu, e não ao que está acontecendo ou que virá a acontecer . O papel do artista para Nin é o de revelar a quintessência do homem (passado, presente, futuro, o mundo interno e externo), e não apenas as duas dimensões (tempo e espaço). A realidade se expressa por meio do dinamismo do símbolo: o realismo é necrofílico e busca a imagem. Este mundo não é apenas estático, natureza morta, mas um tipo de morte em vida. ${ }^{85}$
\end{abstract}

Em The Four-Chambered Heart (1959), os personagens Rango e Djuna, prestes a começar uma vida nova juntos, fazem um ritual em que decidem queimar todos os romances de vertente realista. Djuna justifica essa atitude dizendo:

\begin{abstract}
Todos esses romances que cuidadosamente ocultam a verdade sobre a personalidade, sobre o lado obscuro, sobre a intricada trama, sobre os mistérios. Palavras, palavras, palavras, palavras e nenhuma revelação sobre as armadilhas, os abismos em que os seres humanos se encontram. Que Rango queime todos eles; eles merecem ... romances que prometem experiências, mas que permanecem à margem registrando apenas a aparência, as ilusões, o figurino e as falsidades, sem escavar nenhum poço, sem preparar ninguém para as crises, as armadilhas, as guerras e as ciladas da vida. Sem ensinar nada, sem revelar nada, mentindo sobre a verdade, sobre o presente, sobre a realidade. ${ }^{86}$
\end{abstract}

\footnotetext{
${ }^{84} \mathrm{Ibid}, \mathrm{p} .1$. Realism is a bad word. In a sense everything is realistic. I see no line between the imaginary and the real. I see much reality in the imagination.

${ }^{85}$ Hinz, The Mirror and the Garden, p. 12. In view of her objections to the realists it should now be fairly obvious why Nin found their "mirror" to be not the conveyor of the real but the perfect symbol of unreality and refraction. The mirror reflects only the external, the mask, not the essential man. Also, the artist who records only what is reflected can only be a historian, never a prophet, for all he sees is what has happened, not what is happening, or may happen. The role of the artist to Nin is to reveal the quintessential man (past, present, future, inner and outer), not only the two dimensional scene (time and space). Reality expresses itself through the dynamism of the symbol: realism is necrophilic and seeks the image. Its world is not only static, a still life, but a type of death in life.

${ }^{86}$ Nin, The Four-Chambered Heart, p. 48. All this novels so carefully concealing the truth about character, about the obscurities, the tangles, the mysteries. Words, words, words, words and no revelation of the pitfalls, the abysms in which human beings found themselves. Let him burn them all; they deserve their fate... Novels promising experience, and then remaining on the periphery, reporting only the semblance, the illusions, the costumes, and the falsities, opening no wells, preparing no one for the crises, the pitfalls, the wars, and the traps of human life. Teaching nothing, revealing nothing, cheating us of truth, of immediacy, of reality.
} 
Para Hinz, Nin utiliza o termo "realidade" em contraposição ao termo "realismo" para nomear sua perspectiva filosófica e poética. Seu conceito de realidade não nega o mundo empírico. Contudo, o que Nin realmente pretende realizar é questionar a natureza do mundo real. E aqui, é preciso mencionar que a autora, como bem apontou Henry Miller em seu ensaio Un etre etoilique, é uma discípula direta do movimento Transcendentalista norte-americano, cujos principais expoentes foram Emerson, Thoreau e Whitman.

O conceito de Nature definido por Emerson está intimamente relacionado à sua noção de realidade. Em seu ensaio Nature (1863), Emerson, tal qual Blake, afirma que não há separação entre a consciência humana e o mundo exterior: essas duas instâncias formam uma unidade e são regidas pela mesma lei: a lei da correspondência. $\mathrm{O}$ mundo em sua totalidade é a manifestação de um mundo espiritual e, por isso encontra-se carregado de simbolismo e dotado de sentido. "Não vivemos em meio a fatos, mas em meio a profundezas e símbolos", ${ }^{87}$ explica Rimbaud.

$\mathrm{O}$ artista seria aquele que enxerga com olhos internos e se torna "um globo ocular transparente - the transparent eyeball" e realiza, assim, a leitura simbólica do mundo. É sob essa percepção de realidade que a obra de Nin está ancorada e suas estórias são uma busca de sentido: “O sentido está na base do drama. O sentido ilumina os fatos, os coordena, o sentido está encarnado nos fatos". ${ }^{88}$

Nin não apreciava a estrutura narrativa rígida do romance convencional baseada em uma noção de clímax e desfecho. Achava que esta era uma fórmula artificial. Para a autora, tanto o enredo quanto a construção de personagens deveriam estar submetidos a uma forma de desenvolvimento orgânico. A trama da estória seria criada a partir de padrões da própria mente humana, de associações e seleções realizadas pela memória e da abolição do tempo cronológico. Presente, passado e futuro se tornariam uma unidade. A dimensão onírica e dos desejos se misturariam aos acontecimentos da vida e cada plano exerceria influência sobre o outro.

Dentre os vários artistas que romperam com a estrutura rígida da narrativa e serviram de referência para Nin, Federico Fellini merece destaque especial. Em Fellini

\footnotetext{
${ }^{87}$ Citado por Miller em The Time of the Assassins: A Study of Rimbaud, p. 134. We live not in the midst of facts, but of profundities and symbols.

${ }^{88} \mathrm{Nin}$, The Novel of the Future, p. 52. The significance is the drama. The meaning is what illumines the facts, coordinates them, incarnates them. The creation of a story is a quest for meaning.
} 
81/2, (Otto e Mezzo, 1963) de Fellini, acompanhamos os conflitos de Guido, um diretor de cinema que está prestes a realizar um filme, mas que por algum motivo não consegue desenvolver o argumento. À sua volta, atores, produtores, escritores clamam por um papel, por um enredo, por uma estória com começo, meio e fim. Em meio a esse burburinho, o filme a que nós, espectadores, assistimos, é o filme que se passa na cabeça de Guido: suas lembranças da infância e da juventude, os conflitos de sua vida pessoal, conversas com sua esposa, cenas com sua amante. Em relação ao filme, Nin esclarece:

A confusão e a relação paradoxal entre o que se passa em sua mente e sua memória e o que está acontecendo à sua volta cria uma sofisticada comédia e, em um nível mais profundo, nos dá insights que o enredo tradicional não seria capaz de dar. Diante de nossos olhos, o diretor revela a estória de seu inconsciente, menos para aqueles que estão à sua volta e estes acham que ele está passando por um bloqueio criativo. ${ }^{89}$

Este primeiro capítulo teve como objetivo introduzir o leitor à poética de Nin e aos fundamentos da sua criação literária. $\mathrm{O}$ capítulo seguinte explora a gênese do poema A casa do incesto.

\footnotetext{
${ }^{89}$ Ibid, p. 126. The confusion and the paradoxal relation between what is going on in his mind and memory, and what is going on around him creates high comedy, and on a deeper level, an insight which the standard plot would never have given us. Before our eyes the director reveals his unconscious story to which others are blind, thinking he is impotent and uncreative.
} 
Não tenho interesse algum na vida cotidiana. Busco somente os momentos de êxtase. Vivo em consonância aos princípios surrealistas, em busca do maravilhoso; quero ser uma escritora que lembre as outras pessoas que esses momentos existem; Quero provar que existe espaço infinito, significados infinitos, dimensões infinitas. ${ }^{90}$

\section{Anaïs Nin, Diary I}

Sempre acreditei na liberdade de André Breton, escrever da maneira que se pensa, seguir as sensações, e as absurdas correlações de eventos e imagens, confiar nos novos domínios a que conduzem. O culto ao maravilhoso. Também o culto à supremacia do inconsciente, o culto ao mistério, a fuga da falsa lógica. $O$ culto ao inconsciente como proclamado por Rimbaud. Isso não é loucura. É um esforço para transcender a rigidez e o padrão criado pela racionalidade. ${ }^{91}$

\section{Anaïs Nin, Diary I}

\section{2 - A CASA DO INCESTO E SUA GÊNESE.}

\section{1 - INFLUÊNCIAS DO MOVIMENTO SURREALISTA}

"Escrevi as duas primeiras páginas de meu novo livro de forma surrealista, sob a influência da Transition, de Breton e de Rimbaud. Eles dão à minha imaginação o poder de saltar livremente", ${ }^{92}$ comenta Nin, em seu diário, no ano de 1932, sobre a criação de A casa do incesto. O poema em questão é fruto de uma intrincada e complexa rede de referências. Sua arquitetura é composta por vários planos que se entrecruzam: tanto o surrealismo quanto a escrita do diário exerceram forte influência em sua concepção. Apesar de Nin não ter integrado o movimento surrealista, as ideias de André Breton sobre a capacidade imaginativa do homem e a busca de uma linguagem que

\footnotetext{
${ }^{90}$ Nin, Diary Volume I, p. 5. Ordinary life does not interest me. I seek only the high moments. I am in accord with the surrealists, searching for the marvelous. I want to be a writer who reminds others that these moments exist; I want to prove that there is infinite space, infinite meaning, infinite dimension.

${ }^{91}$ Ibid, p. 11. . I have always believed in Andre Breton's freedom, to write as one thinks, in the order and disorder in which one feels and thinks, to follow sensations and absurd correlations of events and images, to trust to the new realms they lead one into. The cult of the marvelous. Also the cult of the unconscious leadership, the cult of mystery, the evasion of false logic. The cult of the unconscious as proclaimed by Rimbaud. It is not madness. It is an effort to transcend the rigidities and the patterns made by the rational mind.

${ }^{92}$ Ibid, p. 77.
} 
traduzisse a "verdadeira" natureza da realidade, que inclui a dimensão onírica e o maravilhoso, tiveram um papel fundamental no desenvolvimento de sua prosa poética.

\begin{abstract}
Apesar de não ter feito parte do grupo surrealista na década de 30, o surrealismo estava no ar que respirávamos. Tudo era surrealista, todas as pinturas que víamos, todos os filmes. Em certo sentido, minha escrita pode ser considerada surrealista na medida em que se preocupa com a sobreposição, com a vida experienciada em múltiplas camadas. Eu não usava as técnicas surrealistas o tempo todo, e de qualquer forma, os surrealistas não acreditavam no romance. Mas eu reconheço a importância desta influência, sobretudo, a ênfase nos sonhos que inspiraram House of Incest, e a grande necessidade, como Breton dizia, de redescobrir o amor. ${ }^{93}$
\end{abstract}

Para o grupo de escritores e pintores que se reuniram em torno de Breton no período de entreguerras, na cidade de Paris, o ser humano era visto como um campo de experimentações. A experiência poética nasce basicamente da busca de outros estados de consciência, da embriaguez dos sentidos e, sobretudo, da "iluminação profana". Profana no sentido de que esta iluminação não é alcançada por meio da ascese religiosa, mas, sim, pelo despertar de certas forças humanas desconhecidas.

A mente humana é tida como o "grande narcótico" existente. Que língua o homem falaria se dispusesse da rigidez do pensamento racional e se permitisse penetrar no imenso continente perdido: o inconsciente? A obra de arte nasceria de um inusitado contato do homem com ele mesmo, de um état de surprise. Para Antonin Artaud, poeta e dramaturgo francês, "o surrealismo não é um estilo, é o grito da mente que se volta para si mesma". ${ }^{94}$ Assim, para os surrealistas, o romance convencional e a maneira como a literatura fora até então compreendida, não eram mais capazes de comunicar a experiência humana, por isso novas formas de expressão deveriam surgir.

Certamente, Joyce foi o grande expoente dessa busca, particularmente, nos romances Ulisses e Finnegans Wake. Acerca das inovações defendidas pelos surrealistas no campo das artes, Walter Benjamin, em seu ensaio Surrealismo: o último instantâneo da inteligência europeia (1929), afirma:

\footnotetext{
${ }^{93}$ DuBow, Conversations with Anaïs Nin, p. 207: Even though I never joined the surrealist group in the thirties, surrealism was a part of the very air we breathed. Everything was surrealistic, all the paintings we saw, all the films. In a sense my writing is surrealistic only insofar as it is concerned with superimposition, with life experienced on a multiplicity of levels. I didn't use surrealistic techniques all the time, and the surrealists didn't believe in the novel anyway. But I recognize how important the influence was, above all the emphasis on dreams which inspired House of Incest, and the great necessity as Breton said of rediscovering love.

${ }^{94}$ Bradley, Surrealismo, p. 7.
} 
O domínio na literatura foi explodido de dentro, na medida em que um grupo homogêneo de homens livrou a vida literária até os limites extremos do possível [...] a vida só parecia digna de ser vivida quando se dissolvia a fronteira entre o sono e a vigília, permitindo a passagem em massa de figuras ondulantes, e a linguagem só parecia autêntica quando o som e a imagem, a imagem e o som, se interpenetravam com exatidão automática, de forma tão feliz que não sobrava a mínima fresta para inserir a pequena moeda a que chamamos "sentido". 95

Além de poeta, Breton era médico, e foi por meio da medicina que entrou em contato com a obra de Freud. Durante a Primeira Guerra Mundial, trabalhou em um hospital junto a pacientes que, em sua maioria, sofriam de traumas causados pelos horrores da guerra. Essa foi a oportunidade de pôr em prática algumas noções psicanalíticas - a associação livre de ideias e a escrita automática - como método de tratamento. A nova técnica terapêutica, baseada na palavra e desenvolvida por Freud, tinha como objetivo romper com o pensamento lógico e racional e dar vazão ao fluxo da consciência.

Breton enxergou nesse método uma maneira de explorar camadas mais profundas da psique humana em que seria possível criar uma nova linguagem por meio de associações inesperadas. A "escrita automática" foi amplamente difundida pelos surrealistas para fins artísticos. Em relação a Breton, Otávio Paz, em seu ensaio André Breton ou a busca do início, diz:

\begin{abstract}
Amava (Breton) a novidade e a surpresa na arte, mas o termo invenção não era de seu gosto; ao invés disso, em muitos de seus textos brilha com luz inequívoca o substantivo revelação. Dizer é a atividade mais alta: revelar o escondido, despertar a palavra enterrada, suscitar o aparecimento de nosso duplo, criar a esse outro que somos e que nunca deixamos de ser de todo (...) regressar à origem da palavra, ao momento em que falar é sinônimo de criar. Ignoro qual será o futuro do grupo surrealista; estou certo de que a corrente que vai do romantismo alemão e Blake ao surrealismo não desaparecerá. Viverá à margem, será a outra voz. ${ }^{96}$
\end{abstract}

A experiência artística é fruto de uma visão de mundo inteiramente nova. $\mathrm{O}$ propósito surrealista de abolir a dicotomia entre o que chamamos de mundo real e o mundo imaginado levaria a uma outra concepção de realidade, a uma realidade absoluta, a "surrealidade". Poetas como Lautréamont, Appolinaire, Baudelaire e Rimbaud tiveram um papel importantíssimo na elaboração das ideias surrealistas, sobretudo Rimbaud, cuja obra testemunhava sobre a possibilidade de se ir além das fronteiras entre o visível

\footnotetext{
95 Benjamin, "Surrealismo: o último instantâneo da inteligência européia". Em: Obras Escolhidas: Magia e Técnica, Arte e Política, p. 22.

${ }^{96}$ Paz, Signos em Rotação, p. 225.
} 
e o invisível. Rimbaud desejava igualar "a fecundidade da mente com a imensidão do universo" e penetrar no mistério de coisas desconhecidas, para revelar as infinitas possibilidades existentes no tempo presente. No que diz respeito à metafísica surrealista, Balakian (1972) faz a seguinte afirmação:

\begin{abstract}
Um novo tipo de misticismo se desenvolveu cujas sementes foram semeadas muito antes do advento do Surrealismo, mas que veio a se cristalizar com a metafísica do Surrealismo: a transformação da vida, a expansão da visão, poderiam ser experimentadas e expressas no aqui agora, nos limites da nossa existência material e na relação com a realidade física da qual somos parte. $\mathrm{O}$ que torna o Surrealismo único na história da literatura é que há em seu credo uma convergência da crise da linguagem com uma revisão da noção de espiritualidade. ${ }^{97}$
\end{abstract}

Em Anaïs Nin, the Poet, ${ }^{98}$ Anna Balakian defende a tese de que Nin é, em sua essência, uma poeta, com características bastante singulares. Uma dessas características diz respeito ao fato de que Nin não desenvolveu o seu pensamento poético em verso e, portanto, teve de criar uma nova forma de expressão literária que, de certa maneira, transgredisse a divisão rígida dos gêneros literários. Para Balakian, no contexto histórico literário, Nin pertence a uma linhagem de poetas visionários do século 19 ligados ao romantismo, tais como Hölderlin, Novalis, Nerval, Rimbaud e Lautréamont. Esta linhagem adentra o século 20 tendo como seus mais expressivos representantes Valéry, Yeats, Rilke, Claudel. Todos esses poetas empreenderam a tarefa de explorar a natureza da psique humana muito antes de a psicanálise torná-la o seu objeto de estudo. O próprio Freud reconhecia este fato e observou que todos os caminhos que havia percorrido, um poeta já havia passado antes.

Nin realizou um meticuloso estudo da obra de Rimbaud e afirmava que $A$ casa do incesto era a versão feminina de Une saison en enfer. As imagens perturbadoras evocadas por Nin e a criação de uma atmosfera que se assemelha mais a um delírio e a uma alucinação, mantêm forte semelhança com a obra de Rimbaud. Como o poeta francês, Nin também procurou transcender a rigidez do pensamento racional, além de

\footnotetext{
${ }^{97}$ Balakian, Surrealism: The Road to the Absolute, p. 34. A new type of mysticism evolved, whose seeds were sown long before the advent of Surrealism, but which came to crystallization with the metaphysics of Surrealism: that of transformation of life, the expansion of vision, could be experienced and expressed in terms of the here and now, in the confines of our material existence and in relation to the physical reality of which we are part. What makes Surrealism unique in the history of literature is that there is in its credo a convergence of the crises of language with a revision of the notion of spirituality itself.

${ }^{98}$ Balakian, “Anaïs Nin, the Poet”. In: Nalbantian, Suzanne (Ed.). Anaïs Nin: Literary Perspectives, p. 63.
} 
compartilhar de suas prescrições para se tornar um verdadeiro escritor: "O primeiro estudo de uma pessoa que deseja se tornar poeta é o conhecimento total de si próprio. Ela deve explorar sua alma, investigá-la, testá-la, apreendê-la. E quando a conhecer por completo, deve cultivá-la". 99

No Diário Volume $I,{ }^{100}$ Nin confessa que certas experiências deveriam ser evitadas. No entanto, sua curiosidade e imaginação tinham o poder de arrastá-la rumo àquilo que é inexplorado e perigoso, para além de limites conhecidos, com o intuito de transcender sua personalidade. Uma das regras sociais que Nin ousou transgredir, que se tornou motivo de espanto e choque para seus leitores, foi a quebra do tabu do incesto. O relacionamento amoroso que teve com seu pai, a colocou em contato direto com forças irracionais e a lançou no mundo da loucura e da neurose. Foi uma espécie de veneno do qual se sentiu impelida a provar. Impossível, aqui, não citar o conselho dado por Rimbaud aos poetas para se tornarem videntes:

\begin{abstract}
O poeta se faz vidente por um longo, imenso e pensado desregramento de todos os sentidos. Todas as formas de amor, de sofrimento, de loucura; ele busca a si mesmo, ele exaure em si mesmo todos os venenos, para, então guardar apenas a quintessência. Inefável tortura que necessita de toda a fé, toda força sobre-humana e se torna entre todos, o grande doente, o grande criminoso, o grande maldito, - e o supremo sábio! - pois ele chega ao desconhecido. ${ }^{101}$
\end{abstract}

Ao mesmo tempo em que Nin está inserida na tradição Simbolista, também antecipa um estilo de escrita poética dos poetas da geração beat da década de 50 . O trecho seguinte de A casa do incesto poderia muito bem ter sido escrito por Allen Ginsberg (1926-97):

Todos os navios estão a afundar com suas entranhas em chamas e o fogo sibila no porão de cada casa. A carne mais branca do ser amado será cortada pelo vidro e esmagada pela roda. Os longos uivos na noite são uivos de morte. A noite é aliada dos torturadores. O dia é a luz lançada sobre descobertas dilacerantes. Se um cão ladra é porque o homem que aprecia feridas abertas salta pela janela. $\mathrm{O}$ riso precede a histeria. Estou à espera da violenta queda $\mathrm{e}$ da espuma na boca. ${ }^{102}$

\footnotetext{
${ }^{99}$ Rimbaud, I promise to be good: The Letters of Arthur Rimbaud, p.33.

${ }^{100}$ Nin, Diary Volume I, p. 29.

${ }^{101}$ Rimbaud, I promise to be good: The Letters of Arthur Rimbaud, p.33.

102 Nin, House of Incest, p. 17. All the ships are sinking with fire in their bowels, and there are fires hissing in the cellars of every house. The loved one's whitest flesh is what the broken glass will cut and the wheel crush. The long howls in the night are howls of death. Night is the collaborator of torturers. Day is the light on harrowing discoveries. If a dog barks it is the man who loves wide gashes leaping in
} 
A escrita poética de Nin está associada à noção de símbolo. E qual era a sua noção de símbolo? O símbolo era uma unidade da experiência humana que contém diferentes níveis de realidade e que carrega o sentido emocional e espiritual de nossas ações. Para ela, a arte moderna é um retorno ao símbolo. Entretanto, seu interesse não gira apenas em torno da criação de uma linguagem simbólica. Com exceção de $A$ casa do incesto, que é sua experiência ficcional mais radical, Nin busca, em sua obra de ficção, penetrar, analisar e interpretar as várias camadas de sentido contidas no símbolo. A autora afirmava que "tanto o símbolo quanto a sua interpretação poderiam vir a ter relevância maior do que o enredo, o desfecho e até mesmo do que a construção de personagens". ${ }^{103}$ No ensaio The Writer and the Symbols, argumenta:

\begin{abstract}
A arte moderna é um retorno ao símbolo, e o símbolo é o reconhecimento do conteúdo emocional e espiritual de cada ato e cada objeto a nossa volta. A decodificação desse conteúdo deveria ser para nós um grande estímulo a nossa inteligência e ao nosso senso de aventura e exploração. A vida ocidental tornou-se mecânica, funcional e destituída de sentido. E esse é um caminho sem volta, mas existe a possibilidade de dar sentido ao presente por meio de uma escavação até as profundezas, que se encontra submersa nas atividades da superfície e por meio de um equilíbrio entre a esfera emocional e a espiritual para que uma possa se nutrir da outra. O inconsciente humano permaneceu rico em imagens e emoções apesar da pressão externa que vai à direção oposta. O homem não se tornou um robô, mas ele corre o risco de se tornar inarticulado caso aceite o empobrecimento da linguagem e a demasiada simplificação em seu relacionamento com o outro. ${ }^{104}$
\end{abstract}

A técnica de escrita usada por Nin na elaboração de A casa do incesto difere, em alguns aspectos, da escrita automática, como postulada pelos surrealistas. Por vários anos, Nin manteve um caderno em que descrevia seus sonhos, fantasias e devaneios. Entretanto, não era seu propósito apenas registrá-los livremente. Em um segundo momento, esse material deveria ser reescrito e editado para que seu sentido fosse, aos poucos, revelado. Nin não se contentava em apenas justapor imagens: seu desejo era de

through the window. Laughter precedes hysteria. I am waiting for the heavy fall and the foam at the mouth.

${ }^{103}$ Nin, The Novel of the Future, p. 35.

${ }^{104}$ Nin, The Writer and the Symbol, p. 49. Modern art is a return to the symbol, and the symbol is an acknowledgment of the emotional and spiritual content of every act and every object around us. It is the decoding of this content which should become for us a marvelous stimulant to our intelligence and our sense of adventure and exploration. Our Western life has become mechanical, functional, and devoid of meaning. There is no going back but there is the possibility of investing the present with meaning by excavating for depths which get submerged by surface activity, and by maintaining a balance between the emotional and the spiritual so that they can nourish each other. Man's unconscious has remained rich in images and feelings despite all external pressure in the opposite direction. He has not become a robot, but he is in danger of becoming inarticulate if he accepts an impoverishment of language, an oversimplification of relationships to others. 
buscar os pontos de contato entre essas imagens para que a narrativa pudesse fluir de maneira orgânica.

\begin{abstract}
Para capturar o drama do inconsciente, teríamos que iniciar com uma chave, e a chave era o sonho. Mas a tarefa do romancista era de ir em busca do sonho, desenrolar seu sentido, o objetivo era a relação entre o sonho e a vida (...) Alguns escritores tornaram seu fluxo irracional visível mas, como os jornalistas incapazes de extrair deduções filosóficas ou psicológicas de seus achados, eles esvaziaram suas enormes redes repleta de caos e jogaram justaposições absurdas aos nossos pés. Foi isso o que encontraram no fundo do inconsciente. Poucos foram os que deram uma forma, um sentido a esse achado, submetendo-o a uma clivagem e reorganizando-o com inteligência. Coube a nós a tarefa de interpretá-lo. Penso agora em muito dos escritores surrealistas. 105
\end{abstract}

A montagem poética do filme Un Chien Andalou (1929), de Luis Buñuel e Salvador Dalí teve um forte impacto na escrita do poema, especialmente no modo de Nin editar as imagens. É importante mencionar que, em 1952, Hugh Guiler, agora usando o nome artístico de Ian Hugo, realizou um curta experimental chamado Bells of Atlantis $^{106}$ inspirado em A casa do incesto. A película consiste em várias imagens difusas refletidas na água que se misturam à tonalidades de diferentes cores e, ao fundo, a voz de Nin, recitando trechos do poema, junto à música eletrônica composta por Louis e Bebe Barron.

Nin argumenta que o inconsciente não pode se expressar diretamente porque é um composto do passado, do presente e do futuro. Contém em si muitas dimensões e, por isso, se apresenta indiretamente por meio dos sonhos. Sua definição de sonho não se restringe apenas aos sonhos noturnos, mas engloba qualquer imagem ou ideia que foge ao controle da mente racional: visões, devaneios, alucinações, delírios. Uma frase de Jung que Nin cita e que dá título ao primeiro capítulo do livro The Novel of the Future é: "proceed from the dream outward", ou seja, proceda do sonho para o real. Essa frase

\footnotetext{
${ }^{105} \mathrm{Nin}$, The Novel of the Future, p. 118. To capture the drama of the unconscious, one had to start with the key, and the key was the dream. But the novelist's task was to pursue this dream, to unravel its meaning; the goal was to reach the relation of dream to life [...] Some writers have brought the irrational streams into visibility but like reporters unable to extract either philosophical or psychological deductions from their findings, they emptied their vast nets filled with chaos and threw debris and absurd juxtapositions at our feet. This was what they found at the bottom of their unconscious. But few gave this a form, a meaning, sifting it and rearranging it with intelligence. They left it all for us to interpret. I am thinking now of many surrealist writers.

${ }^{106}$ Ver o curta em: https://www.youtube.com/watch?v=HE-7qEftad8
} 
aponta para a capacidade da imaginação em moldar e criar novas realidades. Nas palavras de Breton: “Aquilo que é imaginado tende a tornar-se real." 107

André Breton foi um dos primeiros escritores a considerar Freud uma das grandes forças a auxiliar o homem na redescoberta do sentido e da vitalidade das palavras e a dar importância aos sonhos e ao subconsciente. Breton achava que há um ponto da mente em que a vida e a morte, o real e o imaginado, o passado e o futuro, o comunicável e o incomunicável, o alto e o baixo deixavam de ser percebidos como contradições. ${ }^{108}$

Esta dimensão onírica é uma das fontes da qual Nin extraiu imagens e símbolos para compor A casa do incesto. Gaston Bachelard, em A poética do devaneio (1960), diz que "o devaneio nos põe em estado de alma nascente"109 e, através dele, a alma descobre novos mundos, precisamente o seu mundo. Para Nin, visões, sonhos e devaneios seriam a fonte, a chave, o nascedouro de nosso "eu" autêntico, seriam os verdadeiros guias que nos conduziriam à nossa natureza mais secreta. Em uma passagem do Diário $I V$, Nin afirma a sua crença na percepção onírica da realidade.

\begin{abstract}
Sempre vivi nas profundezas. Minha primeira tragédia me lançou ao fundo do mar; moro em um submarino e raramente venho à superfície (...). Aos quinze anos queria ser Joana d'Arc e, mais tarde, Don Quixote. Nunca acordei de minha intimidade com as miragens, e provavelmente terminarei meus dias em uma casa de ópio (...). Morrerei como poeta assassinada pelos não poetas, não renunciarei a nenhuma forma de sonho, não me resignarei a nenhum tipo de feiúra, não aceitarei nada do mundo que não seja o meu mundo. ${ }^{110}$
\end{abstract}

O contato profundo com as imagens inconscientes nos devolveria a capacidade de criarmos a nós mesmos, principalmente em períodos nos quais prevalece a sensação de estagnação e aprisionamento. Estas imagens são, essencialmente, uma forma de sabedoria que nos apontaria o caminho de saída do labirinto. Em Psicologia e Alquimia

\footnotetext{
${ }^{107}$ Citado por Balakian em Surrealism: The Road to the Absolute, p. 13. The imaginary is what tends to become real.

${ }^{108}$ Nin, The Novel of the Future, p. 15. Aqui, Nin parafrasea uma passagem do Segundo Manifesto do Surrealismo. André Breton was one of the first literary writers to accept Freud as one of the great forces in helping man rediscover the meaning and vitality of words and in giving importance to dreams and the subconscious of man. Breton felt that there is a certain point in the mind where life and death, the real and the imaginary, the past and the future, the communicable and the incommunicable, the high and the low cease being perceived as contradictions.

${ }_{109}$ Bachelard, A poética do devaneio, p. 15

${ }^{110}$ Nin, Diary $I V$, p. 177. I have lived in the depths. My first tragedy sent me to the bottom of the sea; I live in a submarine, and hardly ever come to the surface (...). At fifteen I wanted to be Joan of Arc, and later, Don Quixote. I never awakened from my familiarity with mirages, and I will end probably in an opium den (...). I will die a poet killed by the nonpoets, will renounce no dream, resign myself to no ugliness, accept nothing of the world but the one I made myself.
} 
(1944), Jung recorda a antiga máxima latina que diz: Habentibus symbolum facilis est transitus. $^{111}$

Em A casa do incesto, os sonhos estão incessantemente interferindo e se mesclando à percepção que a narradora tem da realidade. Eles também têm o poder de ressuscitá-la sempre que é crucificada: "O sonho! O sonho! O sonho ressoa em mim como um imenso sino de cobre sempre que desejo traí-lo. O sonho me roça inteira com suas asas de morcego sempre que abro os olhos humanos e procuro viver fora de seu domínio. Sempre que a dor humana me atinge de forma violenta, sempre que sou corroída pela raiva, ressuscito, sempre ressuscito após a crucificação (...)". ${ }^{112}$

A psicologia analítica de Jung reverencia as experiências visionárias e as colocam em primeiro plano por serem cruciais no desenvolvimento da psique humana. $\mathrm{O}$ amadurecimento do ser depende do processo de individuação, em que os nossos lados opostos são vivenciados intensamente no plano da consciência para que possam ser integrados. Em Jung, a palavra integração é sinônimo de maturidade. Essas forças opostas que sustentam a vida em nós se manifestam por meio de imagens e visões. Jung esclarece: "Experiências visionárias nada evocam do que lembra a vida cotidiana, mas tornam vivos os sonhos, as angústias noturnas, os pressentimentos inquietantes que despertam nos recantos obscuros da alma". ${ }^{113}$

Visões e devaneios são experiências autênticas e constituem em si expressões de uma essência desconhecida de nós mesmos. A ênfase na mente racional, que restringe e exclui tudo que não é passível de explicação, é o filtro pelo qual enxergamos a realidade. Por isso, em muitos casos, as experiências visionárias são categorizadas como doenças psicopatológicas. Em sua necessidade de exercer controle sobre os acontecimentos da vida e de se sentir seguro, o homem não consegue mais reconhecer a potencialidade de transformação contida no movimento de integração.

A experiência da vida ocorre, para a maior parte dos seres humanos, na camada superficial, em que a energia vital e a atenção estão voltadas para a representação de papéis sociais tanto nas relações de trabalho quanto nas relações familiares. Para Jung,

\footnotetext{
${ }^{111}$ Jung, Psicologia e Alquimia, p. 237.

${ }^{112}$ Nin, House of Incest, p. 21. The dream! The dream! The dream rings through me like a giant copper bell when I wish to betray it. It brushes by me with bat wings when I open human eyes and seek to live dreamlessly. When human pain has struck me fiercely, when anger has corroded me, I rise, I always rise after the crucifixion (...).

${ }^{113}$ Jung, Psicologia e Alquimia, p. 80.
} 
aqueles que se identificam plenamente com suas máscaras sociais conhecerão muito pouco de sua própria natureza e deixarão de explorar outras regiões da alma. Todavia, Jung argumenta que, em maior ou menor grau, todos passamos pelo processo de individuação, pois ele faz parte da estrutura anímica. Acima de tudo, é preciso curiosidade e coragem para penetrar naquilo que nos excede. Este é, certamente, um caminho tortuoso e de inúmeros desvios.

No mundo em que prevalece a mentalidade materialista e prática, os fenômenos metafísicos são banidos ou reprimidos. Esse tipo de leitura da realidade leva, necessariamente, a um empobrecimento da experiência humana que é, a meu ver, a característica mais marcante de nossa época. Nesse contexto, a vida se torna uma experiência de segunda mão. Para vários povos, de tempos e lugares distintos, imagens e visões são elementos fundamentais que estão na própria constituição de suas culturas, são vivências verdadeiras e enriquecedoras em que é possível entrar em contato direto com a dimensão transcendente e metafísica. Na modernidade, tais experiências ainda encontram refúgio na arte e em certos grupos étnicos que sobreviveram ao processo civilizatório. "O artista é, no mais alto sentido, homem, e homem coletivo, portador e plasmador da alma inconsciente e ativa da humanidade". ${ }^{114}$

No belo ensaio On the Trail of Eurydice, ${ }^{115}$ Bertrand Mathieu defende a ideia de que Nin, em sua a obra ficcional, cria um universo inteiramente novo no qual as potencialidades da consciência humana são vivenciadas no ato de leitura. A arte de Nin pode ser traduzida como um esforço consciente em tornar o sonho mais real do que aquilo que entendemos por "realidade". Sua linguagem, envolvente e sedutora, tem o propósito de provar ao leitor que as limitações da vida cotidiana podem ser substituídas por uma outra forma de existência onírica, miraculosa e extática. Em sua constante busca pelo absoluto, Nin desorienta a mente do leitor.

Assim como Balakian (1997), Mathieu chama a atenção para a dificuldade que é tentar encaixar a escrita de Nin em um conceito mais tradicional de "literatura", principalmente dentro de uma classificação rígida dos gêneros literários. Em sua visão, os críticos que realizaram análises convencionais de sua obra se equivocaram e se afastaram enormemente da intenção original da autora. Sua escrita está mais próxima a

\footnotetext{
114 Ibid, p. 90.

115 Mathieu. "On the Trail of Eurydice". In: STUHLMANN, Gunther (Ed.). Anaïs International Journal Volume 10, pp. 63-76.
} 
algo que chama de sorcellerie, ou seja, feitiçaria, do que de um texto literário convencional. A ficção de Nin foi criada segundo os preceitos dos poetas Simbolistas. Suas estórias são longos poemas Simbolistas, são dimensões paralelas habitadas por personagens que só farão sentido se forem compreendidos como símbolos.

\section{2 - A RELAÇÃO ENTRE O DIÁRIO INCEST E A CASA DO INCESTO}

A recepção crítica da obra ficcional de Nin passou por duas mudanças significativas. A primeira ocorreu com o lançamento do primeiro volume do diário ficcionalizado, em 1966. A segunda deu-se com a publicação do diário original, em 1985. Até então, a ligação entre o diário e a ficção era desconhecida. Com a publicação dos diários, foi possível fazer novas leituras da obra, uma vez que o jogo de referências literárias se ampliou enormemente e novos elementos foram postos em cena.

O primeiro volume do diário ficcionalizado e os diários originais Henry and June e Incest, dos anos de 1931 a 1934, compreendem um período crucial e, ao mesmo tempo, bastante conturbado na vida de Nin. Casada, vivendo nos arredores de Paris e tendo publicado apenas um único livro de crítica literária sobre D. H. Lawrence, Nin passa por profundas transformações ao conhecer Henry Miller e sua esposa June. Apaixona-se por ambos e encontra em Henry Miller um grande parceiro literário. Esse encontro e todos os acontecimentos que se seguiram foram retratados, com muita beleza, pelo diretor Philip Kaufman, no filme Henry and June, de 1990. A atriz portuguesa Maria de Medeiros se destaca pela brilhante atuação no papel de Anaïs Nin.

Nin e Miller eram possuídos pelo demônio da literatura e da criação. Entretanto, tinham naturezas inteiramente opostas e, por isso, se complementavam. A união entre os dois era uma espécie de casamento sagrado, que os alquimistas chamavam de coniunctio oppositorum. Era como se juntos gerassem uma terceira natureza de grandeza cósmica, capaz de potencializar o espírito criador de cada um e, até mesmo, de alterar "a órbita dos planetas e o ritmo do mundo". Nin faz o seguinte comentário a respeito de Miller: "Imagino nós dois na Espanha - e tudo está fora de foco, distorcido, ampliado pelo poderoso demônio que nos conduz, o demônio da 
literatura. June é personagem, é material, é aventura, mas a cópula entre um homem e uma mulher no forno da criatividade é uma nova monstruosidade de um novo milagre que irá interferir na órbita dos planetas e alterar o ritmo do mundo e 'deixar uma cicatriz sobre o mundo"". 116

Miller era um escritor que exaltava a vida como ela é, sem subterfúgios ou artifícios. Gostava do exagero, da caricatura, do grotesco e do escatológico. De coisas sórdidas e obscenas. Das prostitutas, dos cabarés e da sarjeta. Admirava a pintura de Hieronymus Bosch e a escrita de François Rabelais. "Henry está no Hôtel Havane escrevendo sobre bosta, úlceras, cancros, doença. Por quê?", ${ }^{117}$ pergunta-se Anaïs Nin. Em contraponto a tudo isso, Nin era quintessência da elegância e do refinamento espiritual. Enxergava a vida como um fenômeno estético e poético. Era profundamente idealista. Henry e June representavam um mundo inteiramente novo que Nin não hesitou em experimentar. Nessa troca, Henry and June se espiritualizam e Nin se naturaliza.

No diário é possível acompanhar cada estágio do processo de criação de $A$ casa do incesto: da elaboração de manuscritos até sua publicação, além da influência direta de obras, artistas, pessoas e lugares, tudo a ser destilado e transmutado em prosa poética. Em um período de três anos, Nin elaborou três manuscritos do poema com diferentes títulos: Mona Pages, Thousand and One Night in Montparnasse e Alraune Manuscript. Um dos motivos pelo qual o livro foi escrito lentamente é que havia muita dor envolvida no processo criativo de Nin. Ela própria esclarece que o livro foi composto somente em momentos de insanidade.

Além de conhecer Henry Miller e June, vários outros encontros importantes marcaram esse período: os psicanalistas René Allendy e Otto Rank; o ator, poeta e dramaturgo Antonin Artaud; seu primo Eduardo Sánchez; a escritora Louise de Vilmorin e Joaquín Nin. Em Incest, Nin vive experiências-limites, de aniquilamento e de dissolução. A autora dá vazão à sua natureza transgressora e é lançada em uma atmosfera de "desregramento dos sentidos" onde as regras sociais são suspensas.

\footnotetext{
${ }^{116}$ Nin, Incest, p. 18. I see us both in Spain - and it is all blurred, distorted, magnified by the great driving demon in both of us, the demon of literature. June is a character, material, adventure, but this copulation of man and woman within the very furnace of creativity is a new monstrosity of a new miracle. It will upset the course of the planets, and alter the rhythm of the world, and "leave a scar upon the world".

${ }^{117}$ Ibid, p. 334. Henry, in the Hôtel Havane, is writing about dung, ulcers, chancres, disease. Why?
} 
Pensando em termos freudianos, é como se as forças subconscientes houvessem engolido o seu superego. Permanece casada e mantém outros relacionamentos. Reencontra seu pai e, por um tempo, se envolvem em uma relação incestuosa.

Em uma tentativa de encontrar alívio para seu sofrimento psíquico, Nin busca apoio na psicanálise, precisamente nas figuras de René Allendy e Otto Rank. René Allendy possuía formação ortodoxa freudiana e cultivava grande interesse pela alquimia e pela astrologia. O conceito de fatalité intérieure, introduzido na obra Problème de la Destinée, foi de grande inspiração para Nin. Allendy argumentava que quanto mais nos aprofundássemos na compreensão de nossa personalidade, mais seríamos capazes de conduzir nosso próprio destino. Caso não nos dedicássemos a essa tarefa, maior seria a probabilidade de passarmos toda uma vida condenados a repetir padrões inconscientes de comportamento e ficarmos presos a determinadas formas rígidas de percepção. Para Allendy, a fatalidade, como é compreendida no senso comum, seria uma espécie de ignorância em relação aos condicionamentos que direcionam nossas ações e escolhas.

Eduardo Sánchez foi quem introduziu Nin a Allendy. Ao notar as transformações na personalidade de seu primo, que estava se submetendo a sessões de análise, Nin e seu marido também se entusiasmaram e decidiram buscar ajuda nesse novo método terapêutico. Entretanto, após certo tempo, Nin interrompe o tratamento por causa de certas limitações na perspectiva analítica de Allendy, especialmente na insistência em categorizar e classificar seu comportamento a partir de conceitos da teoria edipiana de Freud. Outro motivo que gerou desconforto em Nin foi a maneira como a terapia estava sendo conduzida. Allendy queria que Nin se adaptasse ao mundo. Isso era algo que ela se recusava veementemente a fazer. Aparentemente, Allendy não compreendeu que o drama de Nin girava em torno de sua necessidade de criação.

Nin era uma pessoa que tinha um forte senso de humor, apesar de todo o drama psicológico em que estava envolvida. Seu lado jocoso é um atributo importante de sua escrita que é pouco lembrado pelos críticos. Há muitos episódios cômicos nos encontros entre Nin e Allendy. Em um deles, Nin inverte os papéis e se torna a psicanalista de Allendy. Como um astuto investigador, retira várias confissões de Allendy e anseia em descobrir quem é a pessoa humana que está por trás da máscara de psicanalista. 
Nin possuía o dom de se relacionar de forma íntima com as pessoas. Uma de suas palavras prediletas - e que dava título às palestras realizadas junto aos estudantes universitários, na década de 70 - era Furrawn, que tem origem galesa. Seu sentido alude a um tipo específico de conversa que faz com que duas pessoas estranhas, subitamente, se tornem íntimas. Em Incest, além do lado cômico, Nin também encena o lado femme fatale, uma espécie de Don Juan feminino, que sente prazer no jogo da sedução e no abandono dos homens. Para além de seus corpos, Nin desejava possuir suas almas, suas imaginações:

\begin{abstract}
Agora sei que sempre chego a este impasse e que sempre me deparo com a mesma saída - a possessão física; e que eu não estou interessada na possessão física, mas sim no jogo, assim como Don Juan, o jogo da sedução, da loucura, da possessão não apenas dos corpos, mas também das almas dos homens exijo mais do que as putas (...). Eu seduzo os corpos e as almas dos homens e brinco com coisas sérias, sagradas. Como Henry uma vez disse, eu adoro um sacrilégio. Sou uma nova espécie de feiticeira. Os homens de vidas sérias, graves, que não se deixam capturar pela prostituta, os homens menos sujeitos às vontades femininas - são esses os homens que possuo. Sou um veneno que não age apenas na carne, mas penetra em profundezas. ${ }^{118}$
\end{abstract}

Após a experiência de análise com Allendy, Nin ainda sentia que precisava de ajuda, e foi por meio do livro Art and Artist que Miller e Nin descobriram Otto Rank. A novidade na teoria de Rank, que tanto fascinava os escritores, era o foco na vontade criadora para fins terapêuticos. Rank era um profundo estudioso do processo criativo e da personalidade criadora, sendo o artista a figura emblemática em seu modo de conceber a prática psicanalítica. Nin se sentia a própria encarnação da obra de Rank, pois havia vivido e experimentado todos os temas sobre os quais tinha escrito: o duplo, a relação entre ilusão e realidade, o incesto na literatura e nos mitos e o processo criativo como um jogo.

Desde a primeira sessão terapêutica, Nin percebeu que havia muitas afinidades entre eles e achava que finalmente tinha encontrado alguém que compreendesse o seu modo de enxergar o mundo. Rank se mostrou bastante interessado em conhecer a obra de Nin e, após a leitura de seus diários e manuscritos, tornou-se uma das pessoas que

\footnotetext{
${ }^{118}$ Nin, Incest, p. 185 - 186. I know now I am driven to this impasse over and over again, and faced with the same outcome, the physical possession; and that I am interested not in the physical possession but in the game, as Don Juan was, the game of seduction, of maddening, of possessing men not only physically but their souls, too - I demand more than the whores (...). I seduce men's bodies and souls, and I play with serious, sacred things. As Henry said once, I love sacrilege. I am a new kind of enchantress. The man of serious, deep lives who are not captured by the whores, the men who are least subjected to the will of woman - these are the men I possess. I am a poison which does not work into the flesh alone, but into deeper sources.
} 
mais incentivaram sua carreira literária. Rank foi um dos grandes estudiosos do tema do incesto e era um profundo conhecedor de estórias, mitos e obras literárias que envolviam esta questão. Em sua opinião, as narrativas de Nin referentes a este tema tinham um imenso valor, pois, pela primeira vez na história da literatura, o incesto era narrado do ponto de vista feminino. Para ele, isso havia sido a grande façanha literária realizada por Nin. Rank leu as primeiras versões de A casa do incesto e contribuiu para que a autora chegasse a uma síntese de ideias na finalização do poema.

Em relação à terapia de Nin, Rank foi bastante inusitado e pediu a ela que lhe entregasse o diário e suspendesse sua escrita. Seu desejo era de que Nin se dedicasse apenas à ficção e controlasse o seu impulso de ter que escrever, nas páginas do diário, tudo o que lhe acontecia. Por um tempo, Nin conseguiu realizar o seu pedido. Entretanto, reconhecia que o diário agia como uma droga em seu corpo, era o ópio e, ao mesmo tempo, era a muleta que lhe permitia ficar em pé perante o mundo. A conclusão que Nin tirou desse experimento era a de que seria impossível abandonar a escrita do diário, e a de que teria de encontrar um modo de conciliar a escrita ficcional e o diário.

Na verdade, Rank acreditava que o diário era a última defesa de Nin contra a análise, contra o seu processo de cura e de amadurecimento. A escrita do diário a impedia de lidar de forma clara com suas ansiedades e angústias. Durante o processo terapêutico, Nin não conseguia conter o impulso de analisar o analista, de selecionar o que iria dizer e o que iria ocultar, de premeditar a forma como iria agir, de ensaiar estratégias de argumentação. Antes de ir para as sessões, Nin já havia encenado sua atuação nas páginas do diário. Para que o processo terapêutico pudesse fluir, Rank achava que ela deveria interromper esse impulso à escrita, e por isso fez uma espécie de confisco do diário.

Da maneira particular como compreendia a criação, Rank argumentava que o artista precisava destruir para criar e isso seria algo impossível para a mulher, uma vez que ela está muito próxima da vida e do aspecto humano. Em uma das sessões de terapia, Rank pergunta a Nin: “o que você gostaria de se tornar, uma mulher ou uma artista"? Obviamente, Nin sabia que a ideia proposta por Rank era bastante questionável. Haveria infinitas formas de criação. No entanto, Nin suspende o seu julgamento imediato e consegue reconhecer que, em seu desejo de criar sem destruir, terminou quase destruindo a si mesma. 
Em sua teoria, Rank ainda observa que quando um homem é curado de suas neuroses, ele adentra a arte. A mulher, quando curada de suas neuroses, adentraria a vida. Novamente, Nin rejeita essa visão reducionista baseada em uma divisão de papéis entre os gêneros. Sua intenção e seu desejo mais profundo eram de conciliar, ou melhor, fundir a esfera da vida e da arte. A vida teria de ser vivida artisticamente. Sua arte seria sua maneira singular de adentrar a vida e, ao mesmo tempo, a vida seria a fonte em que iria buscar vitalidade para renovar a linguagem literária.

À medida que amadurece, Nin acaba por conciliar todas as dicotomias que lhe foram apresentadas em sua jornada: mulher ou artista? Musa ou criadora? Todavia, houve momentos em que Nin esteve certa de que seria apenas a musa inspiradora dos artistas. Em uma passagem do diário Incest, esclarece que não se importaria em colocar todo seu talento a serviço de Miller e que abdicaria de qualquer ambição em criar sua obra. Miller, sim, era o grande criador. Em sua constante busca de integração e de exploração de um modo autêntico de viver, Nin, aos poucos, abandona a necessidade de procurar por um pai, um guia, um mentor em todos os homens que cruzavam seu caminho. Orfeu não virá resgatar Eurídice. Nin consegue enxergar o fato de que ela é tanto Eurídice, aprisionada no submundo, quanto Orfeu, o herói encarregado da tarefa de libertá-la. Ela é a heroína de si mesma. E, ao contrário do mito, não será sacrificada uma segunda vez.

Para quem acompanhou a tortuosa travessia da heroína Nin ao longo dos diários - da juventude à maturidade -, foi possível perceber as infinitas mudanças pelas quais teve de passar. A sua vida foi regida pelo signo da transmutação, da mobilidade e da vontade criadora. No primeiro diário de juventude, Linotte (1914-20), Nin é uma jovem de personalidade extremamente complexa e de uma capacidade intuitiva bastante aguçada. Seu mundo girava em torno dos irmãos, da obediência à mãe, da ajuda nas tarefas domésticas, das descobertas de se viver em um novo país e de uma nova língua, da religião católica e da ausência do pai.

Nessa época, Joana d'Arc era a grande musa inspiradora. A natureza de Nin era de pura religiosidade e costumava travar inúmeras conversas com Deus: que Deus ouvisse suas súplicas e trouxesse de volta seu pai, que Deus o protegesse da terrível guerra que estava destruindo seu amado país, a França. A ausência do pai havia deixado um enorme vazio emocional em Nin, por isso não se cansava de relembrar o mundo que 
havia perdido: a austeridade do pai, as vezes em que ela e seus irmãos haviam apanhado, o interesse do pai em fotografá-la nua, o som do piano que preenchia todos os cantos da casa, o constante entra e sai de artistas, o choro incontrolável e histérico da despedida. Nessa hora, se agarrou ao seu paletó com tanta força que tinha a impressão que suas mãos iriam ficar ali, presas para sempre.

A distância intransponível que a separava do pai só poderia ser reparada através de Deus: cada vez que ia à igreja receber a comunhão era como se abraçasse e beijasse seu pai. O corpo de Cristo se transmutava no corpo do pai:

\begin{abstract}
No momento da comunhão, ao invés de receber o corpo de Cristo, é como se eu estivesse abraçando e beijando meu Pai. É tão doce. ${ }^{119}$

Esta manhã eu chorei na comunhão, meu coração estava inundado de felicidade, uma alegria sem nome, uma felicidade inexplicável me invadiu e, como havia dito, chorei lágrimas de alegria. Aquele momento em que eu fecho meus olhos, em que converso com meu Pai, em que beijo meu Pai, deixa em mim uma sensação que dura o dia todo. ${ }^{120}$
\end{abstract}

A comunhão era o momento em que Nin se unia ao corpo do pai, era a consumação física entre pai e filha através de Deus. No diário Henry and June (193132), Nin relembra as sensações que sentia na infância, ao participar dessa espécie de missa sacrílega:

(...) eu recebia meu pai no lugar de Deus, ao fechar meus olhos e engolir a hóstia, um tremor extático, abraçava meu pai, comungava com ele, em uma mistura de êxtase religioso e paixão incestuosa (...). A hipocrisia em meus olhos abaixados, a explosão secreta de lágrimas à noite, a obsessão secreta e voluptuosa. $^{121}$

O tempo transcorreu e as obsessões que tanto assombravam Nin foram ficando distantes. A transição da juventude para a fase adulta aconteceu com muitas dificuldades, pois sua mãe era a única responsável pela criação e sustento dos três filhos. Aos dezoito anos, Nin se casa e pode então gozar de uma vida sem maiores

\footnotetext{
${ }^{119}$ Nin, Linotte, p. 48. At the moment of Communion, it seems more as though I am kissing and hugging Papa, rather receiving the body of Christ.

${ }^{120}$ Ibid, p. 48. This morning at Communion I wept, my heart was full of happiness, a nameless joy, an unexplainable happiness came over me, and as I said, I cried tears of joy. That moment when I close my eyes and speak to Papa and kiss him makes an impression on me that lasts all they long...

${ }^{121}$ Nin, Henry and June, p. 245. (...) I received my father in place of God, closing my eyes and swallowing the white bread with blissful tremors, embracing my father, communing with him, in a confusion of religious ecstasy and incestuous passion (...). Oh, the hypocrisy of my lowered eyes, the hidden bursts of tears at night, the voluptuous secret obsession with him.
} 
preocupações materiais. A Anaïs dessa fase é uma mulher que vive em completa harmonia com o marido em um local extremamente bucólico, nas proximidades de Nova York. Passa grande parte de seu tempo junto à natureza e se dedica inteiramente à leitura e à escrita, ao cultivo de seu mundo interior e ao fortalecimento de suas qualidades espirituais. Durante sete anos, Nin habitou essa atmosfera rarefeita e ascética, de inocência, de sonhos idealistas e puritanos. A impressão que se tem é que Anaïs quase não toca o pé no chão.

A mudança repentina para Paris obriga Nin a sair dessa espécie de casulo que havia criado. De um universo introspectivo e bucólico, Nin é lançada em plena efervescência da Paris da década de 1920: do jazz, de experimentalismos artísticos, de liberações comportamentais e sexuais. Era como se estivesse pairando entre dois mundos, sem saber direito em que camada pousar, como se houvesse uma fratura dentro de si. Sentia que a vida parisiense lhe causava constante mal-estar e irritação. A sensualidade dos parisienses era motivo de tormenta e náusea.

\begin{abstract}
A vida parisiense, estou convencida agora, é uma constante fonte de irritação para mim. Por que? Não sei. Bem no fundo, além da superfície brilhante, eu sinto fortemente as impurezas dessa vida. (...) idealismo, subitamente se encolhe e vira pálido sentimentalismo e a fruta fica amarga na minha boca. Eu permaneço no mesmo lugar, só que não paro de tremer e sentir náusea. Minha reação à sensualidade me causa infinita dor. ${ }^{122}$
\end{abstract}

Esta passagem, escrita em 1925, revela o choque entre o mundo antigo e as novidades inquietantes que esse outro mundo lhe apresentava. $\mathrm{Na}$ primeira linha do diário seguinte, de 1927, o leitor fica sabendo que o sentimento de mal-estar e náusea sentido, em relação à vida parisiense, toma proporções bem maiores: "Existe algo que está desenvolvendo o que há de pior em mim". ${ }^{123}$ Do modo como percebia, todas as suas qualidades espirituais haviam se evadido. Nada fazia sentido. A única explicação que conseguia achar para o que estava acontecendo era que a forma de ascetismo que praticara antes deveria ter sido falsa. Alguma coisa anormal estava despertando em seu ser. Algo desconhecido, que não conseguia nomear. Era como se seu lado físico

\footnotetext{
${ }^{122}$ Nin, Journal of a Wife, p. 142-143. This Parisian life, I am convinced now, is a constant source of irritation to me. Why? I don't know. Deeply, beyond the surface glow, I feel the impurities of it keenly. (...) idealism suddenly dwindles to a pale sentimentalism, and the fruit turns bitter in my mouth. I stand in the same place, but shivering, nauseated. My reaction to sensuality causes me infinite pain.

${ }^{123}$ Nin, Early diary of Anaïs Nin 1927-1931, p. 1. Something or other has been developing the worst in me.
} 
estivesse tentando se impor, como se distanciasse, cada vez mais, dos arroubos idealistas.

Em um ato desesperado, com o intuito de resgatar sua vida anterior, Nin dedicase fervorosamente a casa, à família e aos amigos. Tudo em vão. Essa estratégia não surte efeito: "Estou feliz e cheia de ideias apesar do despertar estrondoso do Diabo que mora dentro de mim". ${ }^{124}$ No meio de todas essas sensações, percebia que algo mais estranho ainda estava acontecendo. Era a sua imaginação que, de repente, dera um salto. Não restaram dúvidas a Nin que, daquele momento em diante, iria poder realizar tudo o que sempre sonhara.

Todos esses estranhos fenômenos vivenciados dizem respeito ao despertar de certas forças psíquicas que estavam adormecidas e que buscavam se integrar, novamente, à esfera consciente. Tais fenômenos são conhecidos como metamorfoses do ser, ou a árdua tarefa de "remembrar-se". A heroína Nin transita entre mundos. Durante a leitura dos diários é possível perceber, claramente, a mudança de um movimento de ascensão para um movimento de queda.

Apesar de a escrita do diário, a princípio, implicar uma noção linear de tempo, existe um outro movimento acontecendo que rompe com essa ideia de linearidade e instaura um outro tempo: o tempo da poesia, da imaginação, do profético. Essa verticalização do tempo desperta novamente a imaginação ativa do ser humano. A saber, o seu gênio poético e profético, que tem o poder de relembrá-lo quem ele realmente é. "Ai, Luz que permanece no meu corpo e cara: / Como foi que desaprendi de ser humana?", ${ }^{125}$ pergunta-se Hilda Hilst, em Tu não te moves de ti.

Blake chama esse fenômeno de As núpcias entre o céu e o inferno. Para os gregos, esse era o despertar do daemon: seres intermediários que vivem entre os deuses e os humanos. Era através dele que os humanos podiam conhecer, mais profundamente, sua própria natureza. $\mathrm{O}$ daemon seria o responsável por guiar o homem em sua descida ao submundo. Em relação a essa experiência profunda da dualidade, Baudelaire, em Meu coração desnudado diz: "Há em todo homem, a toda hora, duas postulações simultâneas, uma dirigida a Deus, a outra, a Satã’.126

\footnotetext{
${ }^{124}$ Ibid, p. 2. Have been happy and full of ideas even though the Devil in me is awakening noisily.

${ }^{125}$ Citado por Claudio Willer em Um obscuro encanto: gnose, gnosticismo e poesia moderna, p. 433.

${ }^{126}$ Baudelaire, Meu coração desnudado, p. 49.
} 
Ao invés do caminho da moderação, Nin sempre procurou o caminho da expansão. A sensação de estar sendo dilacerada pelos extremos e por múltiplas verdades, a acompanhou em momentos cruciais de sua trajetória. Na verdade, esse era seu modo natural de buscar um real equilíbrio: criar um espaço amplo dentro de si para abrigar os extremos e as verdades contraditórias. No fundo, sabia que todos os opostos se complementavam para, assim, formar uma unidade. Simultaneamente, Nin era o espaço vazio e todas essas contradições. E, assim, pôde fluir em meio às experiências da vida. Em um sentido mais profundo, esse estado de espírito era uma forma de desapego praticado na esfera mais íntima do ser, uma sabedoria maior que a colocou em contato com forças inconscientes e ampliou sua capacidade visionária. Por isso, gozou de uma vida em outro plano de consciência.

No diário seguinte, Incest (1931 a 1934), o leitor se depara com uma Anaïs inteiramente transformada. Este é um período intenso de várias mortes e renascimentos. Nin costumava dar títulos aos cadernos que compunham o seu longo diário. Em Incest, todos os títulos refletem as profundas mudanças sofridas pela autora. Sob o nome Incest estão os seguintes títulos: La Folle Lucide, Equilibre, Uranus, Schizoide and Paranoia, The Triumph of Magic - White and Black Magic, Flagellation, And on the Seventh Day He Rested from His Work, Quoted Negligently from a book I Never Read, Audace, The Definite Appearance of the Demon e Flow - Childhood - Rebirth. Além de evidenciar todas as formas de provações pelas quais Nin teve de passar, o conjunto dos títulos, também, evoca movimentos de ascensão e queda: os pares opostos que foram sendo integrados em seu ser e em sua escrita poética.

Em Linotte, Nin prevê algumas de suas experiências da idade adulta. De forma intuitiva, consegue perceber aspectos sutis e ocultos da consciência humana. Na passagem seguinte, Nin, aos treze anos, sente que a vida é um imenso abismo e que deverá percorrer todo o caminho até chegar ao fundo:

Diante de mim há um profundo abismo, e se eu continuar a cair sem parar, quanto tempo levarei para chegar até o fundo? Eu imagino que a vida seja esse abismo e o dia que eu chegar ao fundo será o dia em que deixarei de sofrer. Qualquer dia desses, direi ao meu diário: querido diário, cheguei ao fundo. ${ }^{127}$

\footnotetext{
${ }^{127}$ Nin, Diary volume I, p. 246. In front of me there is a deep abyss, and if I continue to fall into it, deeper and deeper, how long will it take me to reach bottom? I imagine that life is such an abyss, and that the day I strike bottom will be the day I cease to suffer. One of these days I will say to my journal: "Dear Diary, I have touched bottom".
} 
Nin viveu várias experiências-limites em Incest, que intensificaram a sensação vertiginosa de queda, de desintegração e de morte. Inúmeras vezes tocou o fundo do abismo. Além do envolvimento incestuoso com seu pai, outro acontecimento dramático narrado por Nin, em Incest, é o episódio do aborto: Nin está grávida de Henry Miller, rejeita a ideia de ser mãe e se recusa a ter o filho:

\begin{abstract}
Noite. Recuso-me a continuar sendo mãe. Fui mãe dos meus irmãos, dos fracos, dos pobres, de Hugh, dos meus amores, do meu Pai. Quero viver apenas para amar os homens e ser artista - amante e criadora. Rejeito a maternidade, o sacrifício, a abnegação. A maternidade é o retorno à solidão, ao dever de doar-se, proteger, servir, entregar-se. Não. Não. Não. ${ }^{128}$
\end{abstract}

Na realidade, todas as circunstâncias em torno da gravidez são obscuras, Nin não dá muitos detalhes em nenhum dos diários. O pouco que ficamos sabendo é que ela procura uma sage femme e realiza um procedimento de interrupção da gravidez, só que sem o resultado esperado. Seis meses depois, realiza outro aborto e dá à luz um bebê morto. Em uma atmosfera de tensão, passa dois dias em uma mesa cirúrgica, tentando dar à luz uma criança morta, que quase lhe custou a vida: “(...) já é quase de manhã, o dia está nascendo, a criança não vem e estou perdendo minhas forças, e as injeções não induzem o espasmo. O corpo - nem os nervos nem os músculos fazem coisa alguma para expelir essa criança. Apenas a minha vontade e a minha força". ${ }^{129}$ Esse acontecimento também foi posteriormente narrado em uma estória chamada Birth, que compõe o livro de contos Under a Glass Bell (1944). Em uma leitura simbólica de tudo que havia vivido durante esse episódio, Nin afirmava que a criança dentro dela havia morrido para que a criadora pudesse nascer e, por isso o título da estória: "Nascimento".

$\mathrm{Na}$ manhã seguinte, ainda na clínica e depois de uma noite de terríveis pesadelos, Nin tem uma experiência mística e sente todo o seu corpo se unindo à presença de Deus:

E morri outra vez, como morrera inúmeras vezes. Morri e renasci pela manhã, quando o sol bateu na parede em frente à minha janela. Um céu azul, e o sol na parede (...). Deus penetrou todo meu corpo. Eu tremia e me agitava com uma alegria imensa, imensa. Frio e febre e luz, uma iluminação, uma visitação no corpo inteiro, o tremor de uma presença. A luz e o céu no corpo, Deus no

\footnotetext{
${ }^{128}$ Nin, Incest, p. 330. Night. I refuse to be the mother. I have been the mother of my brothers, of the weak, of the poor, of Hugh, of my lovers, of my Father. I want to live only for the love of man, and as an artist - as a mistress, as a creator. Not motherhood, immolation, selflessness. Motherhood, that is solitude again, giving, protecting, serving, surrendering. No. No. No.

${ }^{129}$ Ibid, p. $379-380$. (...) the dawn is coming, and the child does not come out and I am losing strength, and the injections do not produce the spasm. The body - neither the nerves nor the muscles do anything to eject this child. Only my will and my strength.
} 
corpo, e eu me dissolvendo em Deus. Me dissolvi em Deus. Sem imagens. Eu sentia espaço, ouro, pureza, êxtase, imensidade, uma comunhão profunda e inelutável. Chorei de alegria. ${ }^{130}$

\section{3 - A ORIGEM DOS PERSONAGENS DE A CASA DO INCESTO}

A leitura do diário expõe a complexa rede de relações entre seus personagens e os personagens da obra ficcional. Em Incest, June, Louise de Vilmorin, Eduardo Sánchez e Antonin Artaud serviram, respectivamente, de inspiração na elaboração dos personagens Sabina, Jeanne, o escritor paralítico e o Cristo moderno em A casa do incesto. A voz da narradora do poema ecoa a própria voz da narradora do diário, Anaïs Nin.

Em Incest, Nin esclarece que seu encontro com June, Louise de Vilmorin, Eduardo Sánchez e Antonin Artaud teve um grande impacto em sua subjetividade. Para ela, era como se houvesse entrado em contato com os seus próprios duplos, ou seja, era como se, de repente, estivesse cara a cara com versões distorcidas de si mesma. Suas personalidades e suas obsessões lhe eram estranhamente familiares e evocavam a sensação de unheimlich.

Nin destaca a importância da leitura do romance Le jardin du supplice, de Octave Mirbeau e seu papel na concepção estética de A casa do Incesto. A partir das torturas físicas descritas nesta obra, Nin teve a ideia de buscar correspondências e analogias entre o sofrimento físico e o psíquico. O mundo da neurose, do narcisismo, da loucura, da ansiedade em que Nin, June, Artaud, Jeanne, Eduardo se encontravam presos, em uma espécie de labirinto do self, serviu de substrato para a criação de imagens do poema:

Li o Jardin des Supplices de Mirbeau e me perguntei por que essa leitura tinha me deixado com uma sensação de vazio. Dei-me conta de que a descrição da tortura física era para mim menos poderosa do que a tortura mental. Torturas físicas são banais e familiares. Estamos apenas agora começando a investigar a

\footnotetext{
${ }^{130} \mathrm{Nin}$, Incest, p. 384. And I die again, as I had died again other times. I die and was reborn again in the morning, when the sun came to the wall in front of my window. A blue sky, and the sun on the wall (...). God penetrated my whole body. I trembled and shivered with an immense, immense joy. Cold and fever and light, an illumination, a visitation through the whole body, the shiver of a presence. The light and the sky in the body, God in the body, and I melting into God. I melted into God. No image. I felt space, gold, purity, ecstasy, immensity, a profound, ineluctable communion. I wept with joy.
} 
natureza das torturas mentais. Cada uma destas torturas físicas, transposta para o plano psicológico, daria um romance. Interpretar e encontrar para cada tortura física o seu correlato e sua analogia no mundo psíquico. Tome, por exemplo, o arrancar da pele. Isso poderia simbolizar a hipersensibilidade. A morte provocada pelo barulho dos sinos da igreja poderia simbolizar os sons da alucinação. Esse se tornou o tema de House of Incest e ajudou a coordenar as descrições de estados de ansiedade. ${ }^{131}$

Antes de chegar à versão final de $A$ casa do incesto, Nin elaborou vários manuscritos, um deles chamado Alraune. Os personagens dessa primeira versão eram três mulheres, Alraune I, Alraune II e Alraune III que se relacionavam com um único personagem homem, que não tinha nome e era inspirado em Henry Miller. A título de curiosidade, Alraune era a personagem principal de um filme alemão de 1928 chamado La Mandragore, que havia exercido um enorme fascínio sobre Nin. Alraune possuía todos os atributos da femme fatale, era a mulher que nenhum homem conseguia satisfazer. Além disso, Nin achava que a atriz que representava Alraune, Brigitte Helm, tinha uma aparência bastante semelhante com June. Em uma carta enviada a Henry Miller, em primeiro de novembro de 1933, Nin explica as novas mudanças no enredo de Alraune:

Tenho planos para Alraune one. Não mais o nascimento das três Alraunes e o homem, mas personagens separados, desconectados (June, Louise, Artaud e Eduardo), que se relacionam apenas comigo (Mandra), como estórias distantes de doenças distintas. A mentirosa, a ascética louca, a loucura de Heliogabalus, o paralítico. (...) darei um tom dramático e irei intensificar cada um deles com todas as manifestações de suas obsessões. Naturalmente, você não pertence mais a esse enredo. ${ }^{132}$

A composição da personagem Sabina surgiu do magnetismo e da atração que a figura de June exercera sobre Nin. Ela era a representação de tudo aquilo que Nin temia e ansiava. O duplo que evocava a sensualidade, o prazer e a perversidade; a força da beleza destrutiva e a anunciadora do caos. Não possuía uma identidade definida e tinha

${ }^{131}$ Nin, Diary Volume I, p. 311. I read the Jardin du supplices of Mirbeau and wondered why it left me cold. Realized it was because the description of physical torture was, for me, so much less potent than mental tortures. Physical tortures are banal and familiar. Mental tortures we are only now beginning to delve into. Each one of these physical tortures, transposed into a psychological plane, would be novel. Interpreting each physical torture as having its correlation, analogy, in the psychic. Take, for instance, the peeling of the skin. That could become a symbol for hypersensitiveness. The death by the loudness of the church bells could be the sounds of hallucinations. This became the theme of House of Incest and it helped to coordinate the descriptions of anxieties.

132 Nin, Miller, A literate Passion: Letters of Anaïs Nin \& Henry Miller, p. 165. I have plans for Alraune one. No longer the birth of the three Alraunes and the man, but separated and unrelated personages (June, Louise, Artaud and Eduardo) related only to me (Mandra), like distant tales of distinct maladies. The liar, the mad ascetic, the Heliogabalus madness, the paralytic (...). I will dramatize and accentuate each one with all the manifestations of their obsessions. Naturally, you don't belong there anymore. 
uma capacidade infinita de se reinventar por meio de inúmeras estórias e mentiras que contava. As mentiras eram tantas que chegavam a causar sentimento de repugnância em Nin. Era como se June fosse oca por dentro e existisse somente através de seu reflexo nos olhos de outras pessoas.

Todavia, havia beleza nessa forma de loucura. No fundo, suas mentiras não eram mentiras, eram papéis que encenava para destruir a "realidade" e criar espaço para o surgimento do fantástico e do maravilhoso. June considerava-se um personagem dostoievskiano. Achava sua natureza semelhante à de Stavróghin, que provocava crimes, causava o mal sem recorrer à ação. Na verdade, seu desejo mais íntimo era o de se tornar personagem e ser eternizada em uma obra de arte: "Depois de te conhecer, nunca mais vou saber quem eu sou", ${ }^{133}$ diz Nin, que busca uma espécie de fusão entre a sua natureza e a de June. "Eu me tornei June. Eu absorvi June. Eu fui além de June. E me glorifiquei por conter June". ${ }^{134}$

Ela habita o caos. Nada a detém. Ela é nossa fantasia solta no mundo. Realiza o que outros apenas ousam em sonhos. Sem amarras, representa a vida do nosso inconsciente sem controle algum. Que coragem extraordinária, viver sem nenhuma lei, sem limites, de maneira inconsequente. ${ }^{135}$

No rol de personagens da obra ficcional de Nin, Sabina é a mais importante. Além de House of Incest, ela também aparece nas seguintes obras: A Spy in the House of Love, Seduction of the Minotaur, Ladders to Fire, Children of the Albatross e The Four-Chambered Heart. Em todas elas, Sabina representa a força irracional e inconsciente.

Sabina, também, foi criada em contraposição à personagem Mona, do romance Tropic of Cancer (1934), de Henry Miller. Para Nin, Mona era uma imagem distorcida e caricatural de June. Em um sentido mais profundo, Henry Miller não havia compreendido o que ela representava e fracassou em transpor ao plano literário a complexidade da natureza e da maneira de agir de June. Esse suposto fracasso se deve,

\footnotetext{
${ }^{133}$ Nin, Volume I, p. 21. I will never know again who I am.

${ }^{134}$ Nin, Miller, A literate Passion: Letters of Anaïs Nin \& Henry Miller, p. 120. I became June. I absorbed June. I went beyond June. And I glorified myself for containing June.

${ }^{135}$ Nin, Diary I, p. 45. She lives within chaos. Nothing can control her. She is our fantasy let loose upon the world. She does what others only do in their dreams. Mindless, the life of our unconscious without control. There is a fantastic courage in this, to live without laws, without fetters, without thought of consequences.
} 
em grande parte, ao fato de Miller ter aprisionado Mona/June dentro dos limites de uma escrita realista.

Assim, o propósito de Nin, ao criar a personagem Sabina, em A casa do incesto, era o de expor a força mítica e simbólica de June por meio de uma linguagem surreal e poética. Para além do poder destrutivo e de seu lado inconsequente, June possuía uma natureza ambivalente, pois incitava Nin e Miller à criação literária. Para ambos, June era a encarnação de uma esfinge, um enigma vivo que precisava ser decifrado. Neste aspecto, ela é outra versão da personagem Nadja, da obra homônima de André Breton de 1928. No que diz respeito às diferentes abordagens literárias de June, Nin diz no diário:

\begin{abstract}
Henry escrevia sobre June de uma forma muito realista, muito direta. Para mim, ela não deveria ser abordada dessa maneira. Eu escrevi de uma forma surrealista. Levei em conta seus sonhos, o mito de June, suas fantasias. Eu enxergo o simbolismo de nossas vidas. Vivo em dois planos, o humano e o poético. Vejo as parábolas, as alegorias. Sentia que ele buscava o realismo e que eu poderia voar até a minha estratosfera e pesquisar a mitologia de June. Eu procurava descrever o sentido oculto. Todos os fatos sobre June eram inúteis em minha percepção visionária de seu "eu" inconsciente. A destilação que eu fazia não era mero brocado, mas estava repleta de sentido. ${ }^{136}$
\end{abstract}

Antonin Artaud tornou-se personagem importante na obra de Nin. Além de servir como inspiração para criar o personagem do Cristo moderno em A casa do incesto foi, também, o modelo para a criação de Pierre na estória "Je suis le plus malade des Surréalistes" do livro de contos Under a Glass Bell. René Allendy foi quem apresentou Nin a Artaud, que também se entusiasmara com o novo método terapêutico. O que mais chamou a atenção de Nin no primeiro encontro que teve com Artaud foram seus olhos de delírio e de alucinação. Estava certa de que ambos tinham fome de poesia, que eram almas que se aventuravam por regiões misteriosas e que traziam nas mãos o fogo sagrado e amaldiçoado.

Nin relata que era capaz de sentir a dor e a hipersensibilidade do corpo de Artaud. Ele falava como um Hamlet e se identificava com Heliogabalus, o imperador romano insano e devasso. Era, também, o monge que se apaixonara por Joana d'Arc no

\footnotetext{
${ }^{136}$ Ibid, p. 131. Henry was writing about June so realistically, so directly. I felt she could not be penetrated that way. I wrote surrealistically. I took her dreams, the myth of June, her fantasies. I see the symbolism of our lives. I live on two levels, the human and the poetic. I see the parables, the allegories. I felt that he was doing the realism and that I could go up in my stratosphere and survey the mythology of June. I sought to describe overtones. All the facts about June are useless to my visionary perception of her unconscious self. This was a distillation. But it was not mere brocade, it all full of meaning.
} 
fime de Carl Dreyer de 1928. Sua linguagem era a linguagem dos nervos. Sua missão era ressuscitar as forças sagradas, mágicas, primitivas, alquímicas e poéticas do teatro. A encenação deveria ser, novamente, um rito de transformação para os atores e a plateia. O palco era o local sagrado de purificação. Toda a violência contida no ser deveria vir à superfície. Todo o grito de dor, de ódio, de raiva, gestos, uivos, movimentos espasmódicos, música, dança, iluminação, sonhos, uma espécie de catarse e exteriorização coletiva. O teatro como arte total.

O teatro era percebido como poesia espontânea que nasce do corpo quando em contato com a potência vital. Era um experimento visceral que fulminava falsas verdades e que fazia cair todas as máscaras. Não haveria nenhum texto a ser memorizado: "Fazer isso, ligar o teatro à possibilidade da expressão pelas formas, e por tudo o que for gestos, ruídos, cores, plasticidades, é devolvê-lo à sua destinação primitiva, é recolocá-lo em seu aspecto religioso e metafísico, é reconciliá-lo com o universo". 137

Essa era maneira como Artaud concebia o teatro - e que acabou por nomear teatro da crueldade. Todavia, Artaud defendia um tipo de crueldade que tivesse o poder de libertar o homem de suas amarras sociais e psicológicas, que pudesse devolvê-lo a vitalidade. Para ele, o ator teria de ter o poder de transformar a própria anatomia. $\mathrm{O}$ corpo do ator seria um corpo sem órgãos, coordenado apenas por pontos emocionais e afetivos. Ele deveria praticar uma espécie de atletismo da afetividade. "O ator é como um atleta do coração". ${ }^{138}$ Ao entrar em contato profundo com suas emoções, o ator conduziria os espectadores a se engajarem nesse mesmo processo. A encenação, em sua essência, é contagiosa. Toda a energia psíquica liberada no palco induziria todos os que estivessem envolvidos a um estado de transe e de êxtase:

Toda emoção tem bases orgânicas. É cultivando sua emoção em seu corpo que o ator recarrega sua densidade voltaica. Saber antecipadamente que pontos do corpo é preciso tocar significa jogar o espectador em transes mágicos. É dessa espécie preciosa de ciência que a poesia no teatro há muito se desacostumou. Conhecer as localizações do corpo é, portanto, refazer a cadeia mágica. E com o hieróglifo de uma respiração posso reencontrar uma ideia do teatro sagrado. ${ }^{139}$

\footnotetext{
${ }^{137}$ Artaud, O teatro e seu duplo, p. 77.

${ }^{138}$ Ibid, p. 151.

${ }^{139}$ Ibid, p. 160.
} 
A única qualidade que Artaud exigia do ator era que ele trouxesse dentro de si verdade. A ideia de talento era completamente dispensável. O teatro de Artaud foi uma reação contra o teatro da representação e de preceitos naturalistas. Suas ideias exerceram forte influência no teatro de vanguarda realizado posteriormente por Jerzy Grotowski e Peter Brook. Artaud comparava o teatro à peste. Em sua visão, essa era uma doença superior que levava ou à morte ou a uma completa purificação do homem.

A peste, como se mostrou em determinados momentos na história da humanidade, causava uma espécie de delírio na mente e, por isso, intensificava sua energia. Ao desorientar todos os sentidos, despertava conflitos latentes e dava ao homem o poder necessário para realizar gestos extremos. De maneira análoga, o teatro desencadearia uma guerra de símbolos dentro do ser que o levaria a exteriorizar todas as forças submersas e contraditórias. Por fim, a energia liberada durante esse processo deveria ser canalizada para catapultar a consciência humana: que o homem deixasse de ser criatura e se tornasse criador, que se alinhasse novamente ao ritmo cósmico. O teatro de Artaud é, fundamentalmente, um grito de protesto contra a ideia bastante difundida de que a cultura é algo dissociado da vida. A cultura deveria abraçar a vida em toda plenitude, ou seja, em todos os extremos e contradições, para que uma realidade mais profunda pudesse ser revelada. Essa outra realidade mais misteriosa e obscura dificilmente seria representada por palavras.

Se o teatro essencial é como a peste, não é por ser contagioso, mas porque, como a peste, ele é a revelação, a afirmação, a exteriorização de um fundo de crueldade latente através do qual se localizam num indivíduo ou num povo todas as possibilidades perversas do espírito. (...) O teatro, como a peste, é feito à imagem dessa carnificina, dessa essencial separação, desenreda conflitos, libera forças, desencadeia possibilidades e, se essas possibilidades e essas forças são negras a culpa não é da peste ou do teatro, mas da vida. ${ }^{140}$

Antes mesmo de conhecer Artaud e seus escritos, Nin, intuitivamente, no seu dia a dia, já praticava as ideias que ele defendia sobre o teatro da crueldade. Junto às transformações profundas que sofreu, veio a necessidade de encenar, tanto na vida quanto na escrita, o seu drama psicológico. Por meio de ações e gestos, como queria Artaud, Nin exteriorizou toda sua loucura, maldade, angústias, medos, obsessões, repressões sexuais, perversões, fantasias, prazer, amor, desejo de vingança. "Cada

\footnotetext{
${ }^{140}$ Ibid, p. 27-28.
} 
emoção sentida ganhava, imediatamente, uma forma, uma expressão". ${ }^{141}$ Nin tinha necessidade de gestos. Sem dúvida, ao encontrar Artaud, encontrou mais um de seus duplos e, como é da natureza do duplo, algo de muito estranho e mórbido acompanhou essa aparição:

\begin{abstract}
E ele olhou para mim com olhos de absoluta loucura. Completamente louco. "As pessoas acham que eu sou doido", ele disse. Nesse momento, vi em seus olhos que ele realmente era louco e que eu amava essa loucura. Ao olhar para sua boca com os cantos enegrecidos pelo láudano, uma boca que eu não queria beijar, um curioso efeito de sobreposição me lembrou o frescor absoluto da boca e do corpo de Allendy, o frescor da boca de Henry, saudável, frutada, e mais uma vez me senti atraída rumo à morte, sempre rumo à morte, ao fim, ao cume, às insanidades. $\mathrm{O}$ beijo de Artaud era um veneno e eu conhecia esse estremecimento de uma vida espectral. ${ }^{142}$
\end{abstract}

Nin sentia-se fortemente atraída pela imaginação, pelo gênio poético e pela capacidade de abstração de Artaud. Não desejava nenhum outro tipo de proximidade que não fosse a troca de ideias, ao contrário de Artaud. Entretanto, não conseguia expressar seus reais sentimentos e acabou por envolvê-lo em mentiras. Em uma de suas confissões, Nin diz que toda maldade e poder destrutivo que não conseguia exteriorizar na vida real, estavam enclausurados nas páginas do diário: "Com o poder que tenho, quanta maldade eu não faria, meramente contando a Eduardo a verdade sobre ele, sobre Henry, sobre Hugo e sobre Artaud. E esse mal eu faço em meu diário. Meu mal será póstumo - as verdades implacáveis. Sim, todo o mal que não pratico - eu o escrevo". ${ }^{143}$

A presença de Artaud na vida de Nin deu indícios e antecipou a relação incestuosa que ela viria a ter com o pai. Para fins catárticos e de purificação, Artaud incitava a quebra de tabus. No ensaio $O$ Teatro e a Peste, o dramaturgo expõe a admiração pela peça Annabella de Ford, cujo tema era a relação incestuosa entre dois irmãos: Giovanni e Annabella. Os irmãos, ao se lançarem destemidamente em um

\footnotetext{
${ }^{141}$ Nin, Incest, p. 104. (...) every feeling I have has instantaneously a form, an expression.

${ }^{142} \mathrm{Nin}$, Incest, p. 186. And he looked at me with absolutely mad eyes. Absolutely mad. "People think I am crazy," he said. I knew at that moment by his eyes that he was, and that I loved his madness. As I looked at his mouth, whose edges were blackened by laudanum, a mouth I did not want to kiss, by a curious trick of superimposition I remember the absolute freshness of Allendy's mouth and body, the rosiness of Henry's mouth, healthy, fruit-like, and I knew I was drawn to death, to the end, to culminations, to insanities. To be kissed by Artaud was to be poisoned, and I knew those shivers of a spectral life.

${ }^{143}$ Nin, Incest, p. 203. With the power I have, what evil I could do, merely by telling Eduardo the truth about himself, Henry, Hugo, and Artaud, and this evil I do in my journal. My evil will be posthumous the ruthless truths! Yes, the evil I do not act out, I write out.
} 
relacionamento proibido, estariam realizando um ato heróico e transgressor, que teria o poder libertá-los de suas prisões psicológicas.

Outro acontecimento premonitório ocorre quando Artaud convida Nin a ir ao Louvre para ver a uma pintura que tanto admirava e que lhe servira de inspiração na concepção do Teatro da Crueldade. O quadro do século 16, do pintor Lucas van den Leyden, intitulado Lot e suas filhas era uma representação de um episódio bíblico da destruição de Sodoma e Gomorra, do antigo testamento. A narrativa bíblica conta que, em meio ao completo caos e destruição, Lot, suas filhas e sua esposa fogem da cidade. À medida que caminham, a mulher de Lot olha para trás e, então, é transformada em uma estátua de sal. Lot e suas filhas buscam abrigo em uma caverna. Na crença de que não haveria mais ninguém no mundo para seguir a linhagem do pai, as filhas decidem embriagá-lo e, então, se entregam a uma união incestuosa. ${ }^{144}$

Em contrapartida, na pintura de Lucas van den Leyden, o pai se torna aquele que seduz. No primeiro plano, vemos uma de suas filhas apanhando um jarro enquanto Lot desfruta do corpo da outra filha, em uma atmosfera de plena calmaria. Ao fundo tudo se deteriora - a cidade é cindida por um raio, rochas se partem, o céu está em brasa. Outro aspecto interessante dessa pintura é que há uma ruptura na linearidade do tempo. Existe duas representações dos personagens envolvidos em tempos diferentes. Uma - no primeiro plano, quando já estão salvos; a outra ao fundo, quando ainda estão fugindo do terror. Ainda é possível ver a esposa de Lot transformada em estátua. A união entre o extremo prazer e o terror absoluto exerceu um forte fascínio em Artaud e despertou sua imaginação para criar outra forma de arte que tivesse raízes no âmago da vida, uma arte que pulsasse junto ao ritmo cósmico.

Nin, naturalmente, se encantou com a pintura de Lucas van den Leyden. Em uma carta, ${ }^{145}$ Artaud diz que já havia introduzido esta pintura a muitas pessoas, mas essa era primeira vez que via uma obra de arte fazer um ser vibrar com tanta energia amorosa. Era como se, naquele momento no Louvre, as imagens do quadro relembrassem Nin de sensações que ainda viria a experimentar junto ao pai: 
receosa, parecia que eu ia beijar um irmão, ainda assim fiquei tentada apavorada e cheia de desejos. Estava tensa. (...) Nos beijamos e o beijo trouxe uma onda de desejo. Outro beijo. Mais terror do que prazer. O prazer de algo inominável, obscuro. ${ }^{146}$

Em um dos encontros amorosos que teve com o pai, Nin conta a ele tudo sobre a pintura Lot e suas filhas, sobre como a obra havia feito seu corpo vibrar, e ele diz a ela que depois da experiência extrema que viveram, havia perdido Deus para sempre. Por causa da força simbólica do quadro e de tudo que representava, Nin decide incluí-lo na composição de A casa do Incesto. A narradora do poema, ao adentrar a casa do incesto, cambaleando de um quarto a outro, encontra, de repente, o quarto das pinturas onde estava Lot e suas filhas:

(...) lá estava Lot sentado com a mão sobre o seio da filha enquanto, ao fundo, a cidade em chamas se partia e afundava no mar. Ali, onde estava sentado junto à filha, o tapete oriental era resistente e vermelho, mas o tremor que sacudia seus corpos, também, se revelava nas rochas que se partiam ao redor, na terra que se abria sob seus pés, nas árvores incendiadas feito tochas, no céu esfumaçado e em brasa, tudo se rompendo ao prazer e terror desse amor. O prazer da mão do pai sobre o seio da filha, o prazer do medo que a dilacera. A roupa bem justa para que os seios se avolumem e cresçam sob os dedos do pai, enquanto a cidade é cindida por um raio, e cospe, sob dentes de fogo, enormes blocos de ruínas, que se afundam ao horror da obscenidade, atirados ao mar ao som sibilante daquilo que está eternamente amaldiçoado. Nenhum grito de horror vindo de Lot ou sua filha, apenas o grito da cidade em chamas, de um desejo insaciável de pai e filha, de irmão e irmã, de mãe e filho. ${ }^{147}$

Nin reencontra o pai após vinte anos de separação. Um homem ainda jovem para os seus cinqüenta anos, de traços femininos, espirituoso, que tinha o dom de envolver os outros com as palavras e de seduzir. Havia dedicado a vida à música e, mais profundamente, havia se dedicado à arte de criar a si mesmo. Outra vez, Nin se via face a face com o duplo - o duplo do qual passara a vida toda fugindo. Tudo o que desejava

\footnotetext{
${ }^{146} \mathrm{Nin}$, Incest, p. 209. "Let me kiss your mouth". He put his arms around me. I hesitated. I was tortured by a complexity of feelings, wanting his mouth, yet afraid, feeling I was to kiss a brother, yet tempted terrified and desirous. I was taut. (...) we kissed, and that kiss unleashed a wave of desire. (...) Another kiss. More terror than joy. The joy of something unnamable, obscure.

${ }^{147}$ Nin, House of Incest, p. 34-35. (...) and there sat Lot with his hand upon his daughter's breast while the city burned behind them, cracking open and falling into the sea. There where he sat with his daughter the Oriental rug was red and stiff, but the turmoil which shook them showed through the rocks splitting around them, through the earth yawning beneath their feet, through the trees flaming up like torches, through the sky smoking and smouldering red, all cracking with the joy and terror of their love. Joy of the father's hand upon the daughter's breast, the joy of the fear racking through her. Her costume tightly pressed around her so that her breasts heave and swell under his fingers, while the city is rent by lightning and spits under the teeth of fire, great blocks of a gaping ripped city sinking with the horror of obscenity, and falling into the sea with the hiss of the eternally damned. No cry of horror from Lot and his daughter but from the city in flames, from an unquenchable desire of father and daughter, of brother and sister, mother and son.
} 
era ser diferente dele, mas persistia a sensação de estranha familiaridade. Era como se estivesse olhando no espelho, um tipo de espelho que deforma a imagem. Seus defeitos tomavam proporções maiores, ao ponto de lhe causar náusea. Suas qualidades assumiam um tom caricatural.

A figura do pai "era uma caricatura, um fantasma de suas incertezas, autocríticas, de sua doença". ${ }^{148}$ Havia uma espécie de prazer aterrorizante nas semelhanças entre os dois: "Quando ele se aproxima de mim falando e rindo eu me sinto desconcertada; ele não parece ser meu pai, mas um homem jovem com um charme incrível e uma falsidade fascinante, labiríntica, fluida, irrefreável como a água". ${ }^{149} \mathrm{Na}$ noite do reencontro, Nin sonhou que o pai a acariciava como uma amante e que sentia um imenso prazer.

Em seguida, o pai a convida a passar um fim de semana em Valescure. É nesse local que descobrem a verdadeira natureza do que os unia. O pai se transforma em Le Roi Soleil e Nin é sua noiva mística. Identificavam-se como os "bárbaros mais civilizados". Cada um a sua maneira, havia construído seu próprio universo para satisfazer as vontades de suas almas. Eram fiéis somente a si mesmos e à suas necessidades internas de crescimento. Aos olhos do mundo, eram amorais. Assim como para Gide, as leituras e os autores que buscavam apenas confirmavam tudo aquilo que já sabiam. Viviam muito à frente de seu tempo: "Há vinte anos atrás, meu pai já fazia coisas que só hoje se tornaram comuns. Eu também fui precursora de modas, de estilos; e sei que em "Alraune" há algo que só será entendido daqui a muito tempo. No amor também, só seremos entendidos daqui a muito tempo". 150

Às vezes, durante as conversas que tinham, a máscara de sedutor do pai, era substituída pela máscara do pai da infância e Nin sentia novamente toda a austeridade, o jeito como criticava a todos. Houve uma vez, que Nin, aos oito anos, ficou gravemente doente por causa de uma crise de apendicite, perdeu muitos quilos e seu pai lhe disse o

\footnotetext{
${ }^{148}$ Nin, Incest, p. 156. (...) a caricature, a ghost of my self- doubts, self-criticism, of my malady.

${ }^{149}$ Ibid, p. 156. When he walks up to me talking and laughing I am unsettled, he does not seem to be my father, but a man, a youthful man of infinite charm and fascinating falseness, labyrinthian, fluid, uncapturable like water.

${ }^{150}$ Ibid, p. 201. My father did things twenty years ago which only today are generally practiced. I also foretold fashions, style; and I know there is in "Alraune" a quality that will only be understood much later. Even in love we are understood much later.
} 
quanto estava feia. Ainda quando criança pressentia um "terror obscuro de que nada conseguiria saciar esse homem". ${ }^{151}$

Aos olhos do pai, Nin era "a síntese de todas as mulheres que ele havia amado". ${ }^{152}$ Todos os acontecimentos deixavam transparecer um sentido trágico. A mulher ideal que acabara de encontrar era sua filha. Todavia, não sentia que ela fosse sua filha, e nem Nin sentia que ele fosse seu pai: "Estou apaixonado pela minha própria filha", ${ }^{153}$ diz o pai. Após a primeira união incestuosa, a vontade de Nin era de fugir. O sêmen do pai havia envenenado seu corpo. Não conseguia sentir prazer nessa união entre semelhantes. O chão fugia de seus pés: o dilaceramento interno, a febre da loucura. A vida havia lhe pregado uma peça.

Durante toda a vida, havia procurado, em vão, a presença de seu pai em outros homens e agora que havia possuído seu corpo e alma, era como se estivesse sendo torturada. Mais uma vez provara de um veneno, assim como na relação com Artaud. A relação amorosa que mantinha com os duplos tinha o poder de envenená-la. Na verdade, Nin oscila entre o prazer extremo e a sensação de tortura e, outra vez, encena o teatro da crueldade de Artaud.

Para o pai, esta era uma experiência única, extraordinária, que poucos mortais tinham tido a coragem de viver. Pedia a Nin que tivesse coragem. No fundo, Nin sabia que seu pai não era um sedutor qualquer. $\mathrm{Na}$ verdade, ele era a própria encarnação de Don Juan. Tinha seduzido mais de mil mulheres. E havia um lado de Nin que se deleitava em aprender com ele todas as sutilezas da arte do amor. O pai também havia pedido a ela que guardasse segredo absoluto sobre tudo o que tinha acontecido, até mesmo ao diário, que não escrevesse nada. Nin concordou.

Porém, houve um dia em que todas as formas de neuroses e ansiedades invadiram seu ser. Era como se estivesse sendo lentamente torturada. Não havia ninguém com quem conversar naquele quarto de hotel. Precisava manter sua sanidade mental, e a única saída era relatar nas páginas do diário tudo o que tinha vivido. Seria fiel ao diário. Não iria traí-lo justo no auge de suas experiências. Só que a escrita não trouxe a sensação de alívio que tanto buscava. A tortura prosseguia. Tinha certeza de

\footnotetext{
${ }^{151}$ Ibid, p. 205. As a child I had the obscure terror that this man could never be satisfied.

152 Ibid, p. 208. You are the synthesis of all the women I have loved.

${ }^{153}$ Ibid, p. 208. I'm in love with my own daughter.
} 
que iria morrer sozinha naquele quarto de hotel. Agora só lhe restava queimar o diário. Acordou no dia seguinte surpresa por ainda estar viva.

O diário é, também, um personagem importante na obra de Nin. Pode-se dizer que ele era uma espécie de amante. $\mathrm{Na}$ verdade, dentre todos os amantes de Nin, era o único a quem mantinha completa fidelidade. Henry Miller e seu pai, ora sentiam ciúmes, ora o temiam. Ele era o grande rival.

Com exceção de Henry Miller, que era o Outro, o oposto, Nin se viu envolvida em uma sequência de relacionamentos que tinham o poder de envenená-la. Seus duplos eram uma projeção distorcida de si mesma. Era como se amasse a si mesma no Outro. Uma espécie de amor narcisista, amor de semelhanças. Em relação ao pai, se pergunta: "Que tarefa difícil diante de mim - explorar a vida do meu rei, as torções de sua mente! O terror dá calafrios. Isso é vida ou é morte? Será que esse amor pelo meu Duplo é amor narcisista novamente? Será que me falta força pra enfrentar as dificuldades e dores com o Outro - o Tu - o Toi? Será sempre o moi - meu Pai, minha outra metade masculina?" 154 Nin intuía que o pai, por medo da dor e por causa de seu amor narcisista, daria a alma apenas à "sua própria imagem ou ao seu reflexo", ${ }^{155}$ ou seja, seria capaz de dar o seu amor apenas à filha que havia gerado. Encontrava-se aprisionado na casa do incesto e por isso a sua incapacidade de se confrontar com o Outro. A metáfora do incesto em Nin evoca a ideia de prisão psíquica, de estagnação emocional, de recusa em enxergar o Outro. Toda a simbologia do poema A casa do incesto gira em torno do "Eu" que se relaciona apenas com sua própria imagem no "Outro":

\begin{abstract}
Tudo na casa do incesto fora feito para permanecer imóvel, já que todos tinham medo do movimento e do calor, um medo enorme de que todo o amor e toda a vida se esvaíssem e perdessem. Tudo havia sido feito para permanecer imóvel, e tudo estava apodrecendo. (...) Na casa do incesto havia um quarto que não podia ser encontrado, um quarto sem janela, fortaleza de seus amores, um quarto sem janela onde a mente e o sangue fundiam-se numa união sem orgasmo e sem raízes, como na união dos peixes. A promiscuidade de olhares, de frases, feito faíscas casando-se no espaço. O choque entre suas semelhanças, exalando odor de tamargueira e areia, de conchas apodrecidas e algas agonizantes, o amor feito tinta de lulas, banquete de venenos. ${ }^{156}$
\end{abstract}

\footnotetext{
${ }^{154}$ Nin, Incest, p. 221. What a task before me, to explore all the life of my king, all the twists of his mind. A terror chills me. Is this life or death? Is this love of my double that self-love again? Is it lack of resistance to the difficulties and pains of life with the Other - the Thou - le Toi? Is it always the moi-my Father, the male half of me?

${ }^{155}$ Ibid, p. 248 . He could only give his soul to his own image, or to the reflection of it.

${ }^{156}$ Nin, House of Incest, p. 34. Everything had been made to stand still in the house of incest, because they all had such a fear of movement and warmth, such a fear that all love and all life should flow out of reach and be lost! Everything had been made to stand still, and everything was rotting away. (...) In the house of incest there was a room which could not be found, a room without window, the fortress of their
} 
À medida que o tempo foi passando, os conflitos internos de Nin se amenizaram, a tragédia se atenuou, a sensação de culpa arrefeceu, o amor pelo seu pai, aos poucos, foi se transformando. Em alguns momentos, transformava-se em ódio. Assim, pela primeira vez, Nin conseguiu enxergá-lo com outros olhos: ele deixou de ser a figura divina e enigmática que assombrou sua vida. Nin ainda gostava de provocá-lo, dizendo que iria publicar um livro chamado A casa do incesto. Ao final do diário Incest, Nin celebra sua libertação da casa do incesto: "E eu sorrio ao perceber que não sinto nada por esse professor inumano e severo. Nada. (...) Ah, estou livre! ESTOU LIVRE!". 157 Sim, Nin estava livre para transmutar todas as experiências em arte.

Louise de Vilmorin, amiga de Nin, serviu de inspiração para a criação da personagem Jeanne de A casa do incesto, do conto Under a Glass Bell e do diário ficcionalizado. A verdadeira identidade de Jeanne só foi revelada com a publicação do diário original, na década de 90. Louise de Vilmorin foi uma escritora francesa de família aristocrata. Um de seus livros, Madame de..., de 1951, tornou-se conhecido ao ser adaptado para o cinema pelo cineasta Max Ophüls. O filme, de 1953, também chamado Madame de..., retrata os conflitos vividos pela Condessa Louise e o marido, no período da Belle Époque francesa e é considerado, por muitos, um clássico da sétima arte.

Louise/Jeanne vivia com os dois irmãos em um castelo de quartos infinitos. $\mathrm{O}$ lugar se assemelhava mais a um gigantesco antiquário, ou a um museu. Viviam todos sob uma redoma de vidro, completamente divorciados da realidade, em uma fantasia mórbida de exílio do mundo. Conseguiam apenas relacionar-se entre si, apesar de serem casados e terem filhos. Os casamentos eram uma farsa e a criação dos filhos, apenas uma tarefa a mais a ser realizada. Eram somente fieis às suas semelhanças, aos laços familiares que os uniam. Não conseguiam amar ninguém fora desse círculo. Jeanne esclarece: "Não tenho nenhuma simpatia humana, não sinto dor nem alegria. Tenho

love, a room without window where the mind and blood coalesced in a union without orgasm and rootless like those of fishes. The promiscuity of glances, of phrases, like sparks marrying in space. The collision between their resemblances, shedding the odor of tamarisk and sand, of rotted shells and dying seaweeds, their love like the ink of squids, a banquet of poisons.

${ }^{157} \mathrm{Nin}$, Incest, p. 339-340. And I smile to see I have no emotion - no feeling for this stiff inhuman schoolteacher. None. Oh, I'm free! I'M FREE! 
consciência apenas dos meus irmãos. Sou cheia de medos, um medo enorme que me afasta do teatro, da leitura, da análise, do meu caminho da realização e da clareza". ${ }^{158}$

Assim como Joana d'Arc, Jeanne desejava viver uma vida de heroísmo. Sentiase na Idade Média. Queria ser santa e manter a aura de pureza e inocência. Ela e os irmãos haviam alcançado um estado de plenitude no amor. Após essa experiência, lhes restava somente a morte. E foi o que aconteceu. Estavam todos mortos para a vida. Doía em Jeanne ver os irmãos envelhecerem. O passatempo preferido entre eles era o de ficar conversando, por longas horas, cada um seu quarto, de portas abertas, sem se verem: "Odiamos ter de nos encontrar e trocar beijinhos da maneira humana banal e estúpida, só para manter a farsa dos movimentos e dos gestos humanos". ${ }^{159}$ A relação incestuosa na qual estavam envolvidos acontecia no plano mental e intelectual. Era dentro dessa esfera que encontravam plena harmonia.

Nin conseguia perceber as próprias experiências, seus questionamentos e suas buscas refletidas em Jeanne de maneira distorcida e estranhamente mórbida. Mais uma vez, confrontava-se com um de seus duplos. Compartilhava dos mesmos medos e ansiedades que Jeanne. Assim como sua personagem, Nin sentia-se como se tivesse uma fratura interna. Recusava-se veementemente a se adaptar ao mundo e não conseguia compreender a vida cotidiana. Havia uma deformidade em sua visão que era impossível de ser curada. Vivia como estivesse sempre à margem ou pairando sobre o mundo.

Apesar das semelhanças entre elas, havia algo na família de Jeanne que causava calafrios em Nin e, ao contrário de Jeanne e os irmãos, nunca havia se esquivado do contato humano: “A redoma de vidro que os separavam do mundo era visível à luz. Será que Jeanne conseguia enxergá-la? Será que conseguiria quebrá-la e se libertaria? Mas ela não conseguia vê-la. Beijou a sombra do irmão. Ele despertou. Ela disse: 'deixe-me tocar algo que tenha calor. Salve-me dos meus reflexos. O espelho me assusta"”. ${ }^{160}$

\footnotetext{
${ }^{158}$ Nin, Diary I, p. 16. I have no human sympathy, I suffer neither pain nor feel joy either. I am only aware of my brothers. I know only fears, a great fear which makes me stay away from the theater, from reading, from analysis, from my avenue of realization, of clarification..

${ }^{159}$ Nin, Under a Glass Bell, p. 9. It enrages us to meet and kiss each other in that stupid, ordinary human way, to keep up the great farce of human movements, gestures.

${ }^{160}$ Ibid, p. 13. The glass Bell which separated them from the world was visible in the light. Would she smash it and be free? She did not see it. She kissed the shadow of her brother. He awakened. She said: "Let me touch something warm. Save me from my reflections. The mirror frightened me".
} 
Jeanne e os irmãos continuavam aprisionados em uma redoma de vidro sem conseguir achar o caminho de saída da casa do incesto. Jeanne continuava apenas a beijar a sombra do irmão, ao contrário de Nin, que exteriorizava suas emoções. Em Incest, Nin diz: "Somente sombras! Nunca me contentei em beijar sombras! Eu exigia o corpo. Eu exigia o corpo, a consumação da carne destrói fantasmas. A terrível propriedade terapêutica de se viver apenas!"161

Eduardo Sánchez, primo de Nin, serviu de inspiração para a criação do escritor paralítico, personagem do poema. Desde a adolescência, Eduardo e Nin cultivavam interesses literários. Juntos, liam e discutiam autores. Eduardo também mantinha um diário e era comum entre eles realizar leituras dos diários. Um servia de crítico para o outro. Eduardo se interessava pela poesia de Blake e havia escrito um ensaio sobre o poeta. Por longos anos, cultivou uma paixão por Nin, sem nunca conseguir exteriorizar em gestos ou palavras o seu sentimento. Sofria de uma grave paralisia emocional. Dos quinze aos dezoito anos, Nin esperou ansiosamente por alguma espécie de manifestação amorosa de Eduardo. Muito depois, quando já adultos, Nin percebeu que a estagnação emocional de Eduardo se alastrava para outras dimensões de sua vida e o impedia de fluir em meio às experiências:

\begin{abstract}
Eduardo precisa ser acrescentado à minha coleção de personagens estranhos, à minha mórbida "Alraune", ao universo da insanidade. Ele compra livros que nunca lê; começa horóscopos que nunca termina; compra tintas, mas não pinta nunca; compra uniformes que não usa nunca, a capa espanhola que nunca usa; toma notas para um livro que nunca escreve; sente ciúmes das mulheres que não deseja; deseja as mulheres apenas para abandoná-las, sem as ter lido. ${ }^{162}$
\end{abstract}

É interessante notar, na passagem seguinte, o modo como a escrita do diário é transmutada na prosa poética de A casa do incesto. Nin usa elementos de outros personagens para compor o escritor paralítico e cria algo inteiramente novo. A redoma de vidro, o museu e o violão são elementos que estão associados a Jeanne. A impossibilidade de dizer toda a verdade é uma ideia da própria Nin, protagonista do diário. Em Incest, Nin explica que seria impossível narrar toda a sua estória - todas as

\footnotetext{
${ }^{161}$ Nin, Incest, p. 334. Only shadows! I was not content with kissing shadows! I demanded flesh, and the flesh consummation destroys ghosts. The detestably curative property of sheer living!

${ }^{162}$ Nin, Incest, p. 277. Eduardo must be added to my collection of strange personages, my morbid "Alraune", the universe of insanity. He buys books he never reads; he begins horoscopes he never finishes; he buys paints he never paints with; he buys workmen's suits he never wears, a Spanish cape he never wears; he makes notes for a book he never writes; he is jealous of the woman he does not want; he wants women, only to leave them, unread.
} 
verdades e todas as mentiras - pois, simultaneamente, pensava em mil direções diferentes. Na cena seguinte de A casa do incesto, a narradora sai do livro que está escrevendo, adentra o quarto do escritor paralítico e diz:

\begin{abstract}
Saí de meu livro e entrei no quarto do paralítico. Ele estava sentado, rodeado por inúmeros objetos sob uma redoma de vidro, como em um museu. Havia recolhido uma caixa de tintas que nunca fora usada, milhares de livros com páginas não cortadas, cobertos por poeira. Sua capa espanhola pendurada nos ombros de um manequim, o violão no chão de cordas arrebentadas qual uma cabeleira em desalinho. Sentou-se diante de um caderno de folhas brancas e disse: engulo minhas próprias palavras. (...) Desejo expressar toda a verdade, mas não posso dizer toda a verdade porque teria de escrever quatro páginas de uma só vez, como se fossem quatro colunas simultâneas. ${ }^{163}$
\end{abstract}

Nin utiliza essa mesma técnica de composição em todos os personagens da ficção: os personagens do diário se cruzam e entrelaçam em novas combinações originais. As protagonistas das estórias de ficção - Sabina, Djuna, Stella, Lillian, Renate - são novas combinações de todas as mulheres que constam nas páginas do diário. Esse é um dos motivos pelo qual o leitor fica com a sensação de estranha familiaridade ao se lançar na leitura da obra ficcional de Nin. Refiro-me, aqui, àqueles leitores que já realizaram a leitura do diário. Como um grande quebra-cabeças que é, o conjunto de sua obra poderá ser abordado e lido de inúmeras maneiras e por vários ângulos.

\footnotetext{
${ }^{163} \mathrm{Nin}$, House of Incest, p. 46. I walked out of my book into the paralytic's room. He sat there among many objects under glass as in a museum. He had collected a box of paint which he never painted with, a thousand books with pages uncut, and they were covered with dust. His Spanish cape hung on the shoulders of a mannequin, his guitar lay with strings snapped like long disordered hair. He sat before a note book of blank pages, saying: I swallow my own words. I want to tell the whole truth, but I cannot tell the whole truth because I would have to write four pages at once, like four columns simultaneously.
} 
O caminho que leva à totalidade é feito de desvios e extravios do destino. Trata-se da “longissima via”, que não é uma reta, mas uma linha que serpenteia, unindo os opostos à maneira do caduceu, senda cujos meandros labirínticos não nos poupam do terror.

\section{Carl G. Jung, Psicologia e Alquimia}

\section{3 - UMA POSSÍVEL LEITURA DE A CASA DO INCESTO}

A casa do incesto possui uma estrutura narrativa fechada, pois não há intenção em descrever elementos do mundo externo. $\mathrm{O}$ foco narrativo está centrado na mente da narradora escritora, que empreende uma jornada tortuosa e tenebrosa, ao mesmo tempo em que está escrevendo um livro. Nenhum outro elemento nos é dado acerca de sua natureza. Durante a jornada, se depara com dois personagens - Sabina e Jeanne. À medida que avançamos na leitura, nos damos conta de que Sabina e Jeanne são projeções da própria narradora. Sharon Spencer, em Space, Time and Structure in the Modern Novel, analisa a função de estruturas narrativas que são reduzidas a uma única perspectiva e esclarece:

\footnotetext{
Autores que escolheram trabalhar com uma perspectiva única e exclusiva e excluíram de seus romances elementos externos não desejam explorar o tema. Desejam cativar, capturar e encantar o leitor pela insistência, pela intensidade e pela exposição prolongada para fazê-lo vivenciar uma realidade completamente irreal. O mundo ideal, o fantástico, o surreal, o imaginado, o que foge do padrão realista: cada um desses termos designa certo aspecto da vida cuja veracidade foi negada ou negligenciada pelo empiricista. ${ }^{164}$
}

O poema está estruturado em sete movimentos e uma introdução. O início de cada movimento é marcado com uma espécie de runa - símbolo arcaico sagrado - com o

\footnotetext{
${ }^{164}$ Spencer, Space, Time and Structure in the Modern Novel, p. 47. Authors who have chosen to work with an exclusive single perspective and to close off their novels from surrounding contexts do not wish to explore their subjects. They wish to enthrall, to capture and to enchant the reader by insistence, by intensity and by prolonged exposure, so as to make him experience the reality of the ostensibly unreal. The ideal, the fantastic, the surreal, the imaginative, or the nonrealistic: each is but a term designating some aspect of the life whose veracity is either belied or neglected by the empiricist.
} 
propósito de relembrar ao leitor a natureza mágica das palavras. $\mathrm{Na}$ introdução, a narradora nos fornece elementos essenciais para a compreensão do poema:

Tudo que sei está contido neste livro escrito sem testemunha, edifício sem dimensão, cidade suspensa no céu. Na manhã em que me levantei para dar início a este livro senti, enquanto tossia, algo saindo de minha garganta, a me estrangular. Cortei o fio que o prendia e o arranquei. Voltei para cama e disse: acabo de cuspir meu coração. Existe um instrumento chamado quena feito de ossos humanos. Sua origem está na veneração de um índio por sua amada. Quando ela morreu, o índio fez uma flauta de seus ossos. A quena tem um som mais penetrante e mais misterioso do que as flautas comuns. Aqueles que escrevem conhecem o processo. Foi o que eu pensei ao cuspir meu coração. Só que não espero até que meu amado morra. ${ }^{165}$

Quando diz: "aqueles que escrevem conhecem o processo", Nin se refere ao processo de criação poética. Esta é a questão central do poema, é o fio condutor que une imagens e símbolos e que dá sentido à sua estadia no inferno. Em A casa do incesto, Nin ficcionaliza a forma como vivencia o processo criativo. O poema nasce de suas entranhas. Ao arrancar o fio que prende o coração é como se estivesse cortando o cordão umbilical do poema: seu próprio coração desnudado.

A introdução serve como um prelúdio para a jornada emocional que o leitor irá vivenciar. As palavras serão como o instrumento musical quena: feito de ossos humanos e de som penetrante. O poema, edifício sem dimensão, não foi construído de modo calculado. Sua arquitetura é feita de experiências-limites. Ao contrário do mito de Orfeu, em que Eurídice é sacrificada, Nin não espera até que seu amado morra para narrar as estórias da descida ao submundo. O poema se transfigura em um teatro da consciência encenado no ato da escrita poética, durante as metamorfoses de seu ser.

\footnotetext{
${ }^{165} \mathrm{Nin}$, House of Incest, p.1. All that I know is contained in this book written without witness, an edifice without dimension, a city hanging in the sky. The morning I got up to begin this book I coughed. Something was coming out of my throat: it was strangling me. I broke the thread which held it and yanked it out. I went back to bed and said: I have just spat my heart. There is an instrument called the quena made of human bones. It owes its origin to the worship of an Indian for his mistress. When she died he made a flute out of her bones. The quena has a more penetrating, more haunting sound than the ordinary flute. Those who write know the process. I thought of it as I was spitting out my heart. Only I do not wait for my love to die.
} 
No primeiro movimento do poema, a narradora, consciente de sua incompletude, rememora seu primeiro nascimento na água: lembranças nostálgicas de uma unidade perdida. Naquele mundo, não existia a sensação de falta, apenas plenitude e êxtase. A narradora evoca o mito da Atlântida - paraíso perdido -, que ainda era possível ser encontrado e revivido na rota dos sonhos. Em contraste com a rigidez da cidade nova, a dimensão onírica representa a fluidez, a vida noturna, a Outra voz. Nin incorpora no poema vários elementos de natureza Gnóstica, como a ideia de unidade, da queda, do duplo e da viagem iniciática. O estado de unidade a que o mito da Atlântida faz alusão seria equivalente ao Pleroma para os Gnósticos, o inconsciente coletivo para Jung e a ideia de Oversoul para Emerson: um retorno às origens de nossa vida psíquica.

\begin{abstract}
Minha primeira visão da terra foi através de um véu d'água. Pertenço à raça de homens e mulheres que vêem todas as coisas por uma cortina de mar, e meus olhos são da cor da água (...). Lembro-me de meu primeiro nascimento na água. Tudo em minha volta de uma transparência sulfurosa e meus ossos movendo-se como se feitos de borracha. Balanço e flutuo na ponta sem ossos de meus pés, atenta a sons distantes, sons que estão além do alcance de ouvidos humanos, enxergo o que está além do alcance de olhos humanos. Nascida repleta de memórias dos sinos da Atlântida (...) Não me lembro de ter sentido frio ou calor. Nenhuma dor provocada pelo frio ou pelo calor. A temperatura do sono, sem febre ou calafrio. Não me recordo de ter sentido fome. A comida passava por poros invisíveis. Não me lembro de ter chorado. Sentia apenas a carícia de mover-me - mover-me para dentro de um outro corpo (...) Amando sem consciência, movendo-me sem esforço, na corrente macia de água e desejo, respirando num êxtase de dissolução. ${ }^{166}$
\end{abstract}

A imagem que se segue é a da queda. A harmonia do sonho é desfeita e a narradora é lançada no Kenoma, o mundo da falta e da matéria para os Gnósticos, da separação da alma individual com a alma do mundo. A sensação de exílio acompanha a queda no tempo. Uma longa travessia, cheia de provações, se inicia. A narradora busca, novamente, se integrar, o que será possível somente no encontro com o Outro, com as Outras vozes.

\footnotetext{
${ }^{166}$ Ibid, p. 5. My first vision of earth was water veiled. I am of the race of men and women who see all things through this curtain of sea, and my eyes are the color of water [...] I remember my first birth in water. All around me a sulphurous transparency and my bones move as if made of rubber. I sway and float, stand on boneless toes listening for distant sounds, sounds beyond the reach of human eyes. Born full of memories of the bells of the Atlantide. (...) I do not remember being cold there, nor warm. No pain of cold and heat. The temperature of sleep, feverless and chilless. I do not remember being hungry. Food seeped through invisible pores. I do not remember weeping. I felt only the caress of moving - moving into the body of another - absorbed and lost within the flesh of another [...] Loving without knowingness, moving without effort, in the soft current of water and desire, breathing in an ecstasy of dissolution.
} 
Acordei ao raiar do dia, atirada sobre uma rocha, esqueleto de um navio sufocado em suas próprias velas. A noite me envolveu, uma fotografia descolou-se da moldura. O forro de um casaco rasgado como duas conchas de uma ostra. O dia e a noite descolados um do outro, e eu entre eles, caindo, sem saber em que camada repousar; se na folha mais alta, fria e cinza da manhã ou na camada escura da noite. ${ }^{167}$

Para Jung, a consciência quando se volta para si mesma adentra regiões perigosas e inexploradas, por isso experimenta grande fascínio e horror. Na mitologia, esse fenômeno diz respeito à descida do herói ao Hades. O grande risco dessa travessia é a desintegração da personalidade:

A consciência, ao avançar por regiões desconhecidas da alma, é dominada pelas forças arcaicas do inconsciente. A meta da descida do mito do herói é caracterizada de um modo geral pelo fato deste aventurar-se numa região perigosa (águas abissais, caverna, floresta, ilha, castelo) (...). No fundo, o medo e a resistência que todo ser humano experimenta em relação a um mergulho demasiado profundo em si mesmo é o pavor da descida ao Hades. Se fosse resistência apenas, o caso não seria tão grave. Na realidade, porém, emana desse substrato anímico, desse espaço obscuro e desconhecido uma atração fascinante, a qual ameaça tornar-se tanto mais avassaladora quanto mais nele se penetrar. O perigo psicológico desse momento corresponde a uma desintegração da personalidade. ${ }^{168}$

Ao longo de sua jornada, a narradora encontra Sabina e Jeanne - projeções distorcidas de seu próprio eu. De acordo com Rimbaud, aquele que deseja se tornar poeta deve esgotar todas as formas de amor, de veneno, de sensações, de loucura; sua alma deve assumir um caráter monstruoso. Somente por meio da experiência, o poeta poderia confrontar-se com os outros "eus" que o habitam. É dentro desse contexto que devemos entender a frase de Rimbaud "Je est un autre". Em relação à busca do poeta por esse "outro", Balakian observa:

\begin{abstract}
O entusiasmo pela psicanálise alcançou o seu auge junto aos círculos literários em grau mais elevado do que o próprio culto à Rimbaud. Ali, também, se discutia a questão do "outro" que fez reviver entre os literati referências à Narciso. Os escritores mais sutis da época, como André Gide e Paul Valèry e, também, Anaiis Nin enxergaram nessa figura arquetípica algo mais do que apenas um reflexo do "eu". Eles criaram uma fenda entre Narciso e sua imagem na água. Ao contrário da face bela do Narciso original, surgiu da busca pela auto imagem, não o emblema da superfície, mas a revelação de
\end{abstract}

167 Ibid, p. 6. I awoke at dawn, thrown up on a rock, the skeleton of a ship chocked in its own sails. The night surrounded me, a photograph unglued from its frame. The lining of a coat ripped open like the two shells of an oyster. The day and night unglued, and I falling in between not knowing on which layer I was resting, whether it was the cold grey upper leaf of dawn, or the dark layer of night.

${ }^{168}$ Jung, Psicologia e Alquimia, p. 246. 
outros "eus" que se encontram dormentes, que são mais ambíguos, mais ambivalentes, e às vezes, mais perigosos do que agradáveis. 169

A narradora, ao encontrar Sabina, vê-se face a face com o lado instintivo, gerador do caos, impulsivo e irracional. Ela representa tudo aquilo que jamais será domesticado no ser humano. Mais precisamente, ela é o arquétipo da femme fatale e da força noturna. A narradora deseja unir-se a ela e ocorre uma espécie de simbiose entre as duas personagens. No filme Persona (1966), do diretor sueco Ingmar Bergman, algo semelhante acontece entre a atriz Elizabeth Vogler e a enfermeira Alma. Em meio a vários conflitos, as personalidades das duas protagonistas se fusionam.

Uma das perguntas que a narradora de $A$ casa do incesto se faz é: "SERÁ QUE ALGUÉM SABE QUEM EU SOU?”, grafada em letras maiúsculas como se fosse um grito. E, aqui, mais uma vez, me reporto ao romance Nadja, cujo narrador inicia sua estória com a mesma pergunta "Quem sou?", antes de ser arrastado, pelas ruas de Paris, pela força irracional de Nadja. Em relação a Sabina, a narradora afirma: "Deixarei que me carregues à fecundidade da destruição (...) ESTE É O LIVRO QUE ESCREVESTE E TU ÉS A MULHER QUE EU SOU". ${ }^{170}$

O quarto movimento de A casa do incesto é marcado pelo encontro da narradora com a personagem Jeanne, que vive em uma redoma de vidro e concebe o mundo como uma imensa prisão. Para ela, existe algo de absurdo nos afazeres humanos e na vida cotidiana. "Sua perna a se arrastar para permanecer na terra, uma perna pesada e morta que carrega como se fosse a bola e a corrente de um prisioneiro". ${ }^{171}$ Mais adiante, Jeanne esclarece: “O mundo é pequeno demais. Estou cansada de tocar violão, de fazer tricô, de passear e de ter filhos. Os homens são limitados e as paixões duram pouco.

\footnotetext{
169 Balakian, Anaïs Nin, The poet, p. 69. In: Anaïs Nin: Literary Perspectives, NALBANTIAN (Ed). Nessa citação, a autora se refere à década de trinta. The enthusiasm for psychoanalysis took off in the mores of literary and salon circles in an even more pronounced degree than the Rimbaud cult. It also publicized the notion of the "other" and revived among the literati many references to Narcissus. The more subtle of the writers of the era such as André Gide and Paul Valéry had, like Anaïs Nin, observed in the archetypal figure something more than the overt reflection of the self. They created a wedge between Narcissus and his image in the water. Unlike the pretty face of the original Narcissus, there emerged from their search of the self-image not a surface emblem but the revelation of those other selves that are dormant, more ambiguous, more ambivalent, sometime more ominous than pleasurable.

${ }^{170} \mathrm{Nin}$, House of Incest, p. 13.

${ }^{171} \mathrm{Nin}$, House of Incest, p. 27. Her leg dragging so that she might remain on earth, a heavy dead leg which she carried like the ball and chain of a prisoner.
} 
Fico enfurecida diante de escadas, portas, paredes, enfurecida com a vida cotidiana que interfere na continuidade do êxtase". ${ }^{172}$

Jeanne, em busca de seu irmão, conduz a narradora à casa do incesto. Todos os que estão ali, presos, sofrem de uma espécie de paralisia emocional e afetiva:

Jeanne me levou à casa do incesto [...]. Os quartos eram interligados por degraus - nenhum quarto ficava no mesmo nível do outro - e todos os degraus estavam profundamente gastos. Havia janelas entre os quartos, pequenas janelas de vidro espelhado de modo que era possível conversar no escuro sem ver os rostos uns dos outros. ${ }^{173}$

A metáfora do incesto, em A casa do incesto não deve ser lida somente no plano sexual. Seu sentido tem uma repercussão maior e faz alusão ao amor narcisista, quando enxergamos apenas nosso próprio "eu" no "outro", à recusa do homem à transformação, a um sentimento de impotência e estagnação que o detém em seu processo de crescimento, a um conjunto de neuroses que o impede de se transmutar junto ao fluxo da vida.

A narradora, após o encontro com Sabina e Jeanne e a visita à casa do incesto, volta ao livro que está escrevendo em busca de alívio emocional. Entretanto, não encontra ali nenhum alento e prossegue com suas dores e inquietações internas:

Entrei no meu próprio livro à procura de paz. Era noite e me movi desatenta no interior do sonho; Ao virar bruscamente a esquina me feri em minha loucura. Ver além do que é suportável, a tragédia anunciada no estremecer de uma pálpebra, um crime arquitetado no quarto ao lado, homens e mulheres que se amaram antes de mim na mesma cama de hotel. Carrego esponjas brancas de conhecimento nos fios de meus nervos. ${ }^{174}$

${ }^{172}$ Ibid, p. 28. The world is too small. I get tired of playing the guitar, of knitting, and walking, and bearing children. Men are small, and passions are short-lived. I get furious at stair-ways, furious at doors, at walls, furious at everyday life which interferes with the continuity of ecstasy.

${ }^{173} \mathrm{Nin}$, House of Incest, p. 34. She led me into the house of incest [...] the rooms were chained together by steps - no room was on a level with another - and all the steps were deeply worn. There were windows between the rooms, little spying-eyed window, so that one might talk in the dark from room to room, without seeing the other's face [...] everything had been made to stand still in the house of incest, because they all had such a fear of movement and warmth, such a fear that all love and all life should flow out of reach and be lost! Everything had been made to stand still, and everything was rotting away.

${ }^{174}$ Nin, House of Incest, p. 45. I walked into my own book, seeking peace. It was night, and I made a careless movement inside the dream; I turned too brusquely the corner and I bruised myself against my madness. It was this seeing too much, the seeing of a tragedy in the quiver of an eyelid, constructing a crime in the next room, the men and women who had loved before me on the same hotel bed. I carry white sponges of knowledge on strings of nerves. As I move within my book I am cut by pointless glass and broken bottles in which there is still the odor of sperm and perfume. More pages added to the book but pages like a prisoner's walking back and forth over the space allotted him. What is allotted me to say? Only the truth disguised in a fairytale. 
Sabina, Jeanne e a narradora, saem do livro que está sendo escrito e retornam à casa do incesto, mais especificamente, para o quarto de um escritor paralítico e que logo a narradora o saúda como sendo o Cristo moderno. Ali, também, encontra-se a dançarina sem braços - teve os braços arrancados "por ter se prendido aos momentos felizes da vida e as pessoas que amava." Sobre o Cristo moderno, a narradora diz:

O Cristo moderno enxugou o suor que escorria no rosto, como se ali, sentado, sofresse a agonia de uma tortura secreta. Traços esculpidos pela dor. Olhos bem abertos, como se dilatados pelas cenas de horror. Pálpebras pesadas que sustentam o peso do cansaço do mundo. Sentado numa cadeira como se houvesse fantasmas ao seu redor. Um sorriso feito insulto. Lábios murchos e cobertos pela espuma negra do ópio. Corpo tenso como arame. ${ }^{175}$

Tanto o Cristo moderno - "crucificado por todas as nossas neuroses" - quanto a narradora conseguem compreender o sentido da casa do incesto e compartilham a mesma "linguagem de nervos": "Se ao menos todos pudéssemos escapar desta casa do incesto, onde só amamos a nós mesmos no outro. Se ao menos pudesse salvá-los de si próprios, disse o Cristo moderno"176.

Em suas últimas palavras, a narradora afirma: "Todavia, sabíamos que para além da casa do incesto havia claridade, e nenhum de nós ousava caminhar em sua direção". ${ }^{177} \mathrm{E}$, então, a dançarina começa o seu show, dançando ao som de uma música que só ela escuta, "que contem o ritmo dos ciclos da terra, a girar com a terra girando, virando todas as faces para a luz e para a escuridão igualmente, dançando em direção à luz do dia". ${ }^{178}$

A arte seria uma dos caminhos que Nin aponta para transcender os limites da casa do incesto. Todavia, teria de ser uma arte que não estivesse dissociada das próprias forças que constituem a vida. A dançarina sem braços, quando dança, volta seu rosto

\footnotetext{
${ }^{175}$ Ibid, p. 49. The modern Christ was wiping the perspiration which dripped over his face, as if he were sitting there in the agony of a secret torture. Paincarved features. Eyes too open, as if dilated by scenes of horror. Heavy-lidded, with a world-heavy fatigue. Sitting on his chair as if there were ghosts standing beside him. A smile like an insult. Lips edged and withered by the black scum of drugs. A body taut like wire.

${ }^{176} \mathrm{Ibid}, \mathrm{p}$. 48. If only we could all escape from this house of incest, where we only love ourselves in the other, if only I could save you all from yourselves, said the modern Christ.

${ }^{177}$ Ibid, p. 48. Yet we knew that beyond the house of incest there was daylight, and none of us could walk towards it.

${ }^{178}$ Ibid, p. 51. And she danced; she danced with the music and with the rhythm of earth's circles; she turned with the earth turning, like a disk, turning all faces to light and to darkness evenly, dancing towards daylight.
} 
tanto para a luz quanto para a escuridão. Ao seguir dançando rumo à luz do dia, consegue se libertar da condição de prisioneira.

Ao longo dos capítulos, é possível notar como Nin harmonizou cada influência, cada voz, de maneira original, para criar o poema A casa do incesto. Em seu modo de compreensão, o homem é uma obra inacabada, imerso em um processo contínuo de vir a ser. A casa do incesto é uma metáfora para uma cegueira e uma paralisia emocional que o detém no processo de transformação. 
A multiplicidade das línguas é, certamente, o signo de sua incompletude e de sua transitoriedade, mas o tradutor lê nela também o desejo comum de acabamento. Cada uma à sua maneira, as línguas dizem esta promessa de perfeição que as fundamenta em sua falta e em sua grandeza. E isso não tanto no nível do sentido ou do "conteúdo", mas porque são diversas "maneiras de querer dizer”, são meios de densidade diferente. Ora, a forma de uma língua, o que ela visa na sua especificidade, só pode se mostrar na passagem tradução, Übersetzung - para uma outra língua: só nas diferenças entre as línguas, neste intervalo doloroso que o tradutor pretende, à primeira vista, preencher, mas que, de verdade, ele revela na sua profundidade, só neste intervalo então pode se expor a verdade das línguas... Ou ainda: a verdade do original só pode se dar a ver no afastamento do original, nas diversas transformações e traduções históricas que ela percorre, não na sua imediatez. inicial.

\section{Walter Benjamin, A Tarefa do Tradutor}

\section{4 - COMENTÁRIO SOBRE A TRADUÇÃO}

No campo da tradução, a tradução literária, certamente, ocupa um lugar de destaque por ser terreno fértil para vários tipos de especulações em relação à natureza da linguagem e, mais especificamente, da linguagem poética. Suscitou e continua a suscitar reflexões e muito do que foi escrito no plano teórico surgiu de sua prática. O fato é que nenhum tradutor sai incólume ao confrontar duas línguas e ao explorar as possibilidades de recriação da experiência poética.

O meu propósito ao traduzir o poema $A$ casa do incesto foi o de manter sua aura de opacidade, estranheza e mistério, em outras palavras, sua poeticidade. Esta tarefa não é nem um pouco simples quando pensamos nas diferenças estruturais entre a língua inglesa e a língua portuguesa. Prezei por conservar o modo de expressão conciso e econômico do inglês na tradução e evitar, sempre que possível, inflacionar a frase ou mesmo recorrer a explicações, já que essa é uma tendência marcante da língua 
portuguesa. A leitura crítica que realizei sobre a obra de Nin foi fundamental no processo de tradução e orientou todas as minhas escolhas: na busca por palavras, na forma de estruturação da frase, na escolha de um registro poético na língua portuguesa que acolhesse o poema. Tradução é uma arte, como afirma Paulo Rónai. No caso mais específico da poesia, o tradutor recria quando traduz. Para Haroldo de Campos, a impossibilidade inicial de se traduzir poesia impulsiona o tradutor a assumir uma postura de transcriador. Por isso, tradução de poesia é transcriação.

Um aspecto fundamental da tradução literária, que é pouco discutido, é a esfera da subjetividade. Creio que a sensibilidade e o mundo interno do tradutor precisam, necessariamente, ter pontos de contato com a subjetividade do escritor a ser traduzido. No caso mais específico do universo poético de Nin, aqueles que se aventuram na tradução de seu texto precisam ter uma abertura maior para a dimensão inconsciente: deve haver uma fluidez na comunicação entre o plano consciente e inconsciente. Um exemplo de como o meu inconsciente influenciou o processo de tradução ocorreu quando ainda não sabia, por certo, qual registro poético seguir na língua portuguesa e isso, na verdade, só foi se consolidando à medida que fui avançando na tradução.

Porém, houve um momento, após já ter traduzido algumas páginas, no qual tive um insight precioso, cuja ideia era a seguinte: "leia Almádena novamente". Almádena é um livro de poesia escrito por Mariana Ianelli, que me marcou profundamente e me acompanha desde 2007. Li e reli inúmeras vezes ao longo dos anos. Subitamente, me dei conta de que Almádena girava na mesma órbita que A casa do incesto. Nin e Ianelli compartilhavam de uma sensibilidade estranhamente semelhante. As palavras e a atmosfera de Almádena foram, aos poucos, abrindo espaço para que A casa do incesto pudesse ser recriada em português.

Cada livro é um organismo vivo, vibrante, sensível. Será que existe uma espécie de irmandade secreta entre as obras? Gosto de pensar que, misteriosamente, elas se comunicam entre si. E, aqui, cito uma passagem de Almádena: "É o nervo que arrebenta, / Qualquer coisa que fermenta, / Uma boca e outra boca / No reparte das sobras. / É um tumulto de coxas, / De punhos endurecidos, / O espasmo, a epidemia, / E, ainda assim, não é o bastante". ${ }^{179}$

${ }^{179}$ Ianelli, Almádena, p. 37. 
Um aspecto importante da minha experiência ao traduzir $A$ casa do incesto, foi o de ter em mente a dimensão real da relação que Nin tinha com a língua inglesa. Na primeira leitura do poema, dei-me conta da maneira singular como Nin se expressava em inglês: tanto no uso de um vocabulário incomum quanto no modo de estruturar a frase. Tudo isso me causou grande estranhamento. Nunca tinha lido nada parecido em inglês. A sensação que ficou é a de que Nin havia recriado a língua inglesa. Anos após meu primeiro contato com o poema, ao ler uma passagem do diário Mirages, pude confirmar esse pressentimento: seu projeto literário envolvia um desejo consciente de recriação da língua inglesa. Essa era uma espécie de missão. Nin acreditava que faltava ao idioma inglês sutilezas e nuances presentes na língua francesa.

Em uma conversa com amigo francês Pierre de Lanux, descrita em Mirages, Lanux fala dos vários níveis de sentido da linguagem que certos escritores franceses conseguem explorar e que isso seria algo quase impossível para os escritores ingleses. Nin comenta que, cada vez que tentava explorar diferentes planos de consciência em uma mesma frase - o espiritual, o concreto, o pessoal, o mitológico - sentia-se como se estivesse cometendo um pecado perante a mentalidade inglesa. E Lanux acrescenta: "Um dia você irá acordar escrevendo em francês". Todavia, Nin sabia que isso não iria acontecer. O seu comprometimento com a língua inglesa se dava em um nível bastante profundo, que estava além de explicações racionais: era uma questão de destino.

Eu sei o meu destino. Sei que é um destino doloroso. Estou trazendo nuances à língua inglesa, como um presente. Introduzo sutilezas e aspectos multilaterais que faltam na escrita inglesa. A língua me obedece. Entretanto, será difícil ser ouvida, vista, tocada e amada pela alma e pelo gosto inglês. Escutem-me, leitores ingleses! Estou me sacrificando por vocês. Deixei o meu povo aqueles que compreendem minha língua. Eu os deixei para trazer a vocês melodias sutis e infinitas nuances. Ao fazer isso, procuro dificuldades, serei sempre rejeitada. Vocês não passam de negociantes de simplicidades assombrosas, de desertos, de indiferenciação primitiva. Vocês não possuem sobretons. Faltam a vocês o oblíquo, o indireto, a amplitude, a virtuosidade e maturidade. Ouçam-me! Eu sou o seu músico mais intricado e mutante, eu sei como ampliar seus ouvidos, acrescentar centenas de cores em seus olhos, aguçar seu paladar, expandir seus sentidos. ${ }^{180}$

\footnotetext{
${ }^{180}$ Nin, Mirages, p.147. I know my destiny. It is a painful one. I am bringing those nuances into English, as a gift. I am inserting into English writing the subtlety and multi-lateral aspects it lacks. The language obeys me. But it will be difficult to be heard, seen, touched and loved by the English palate and soul. Listen to me, you English readers! I am sacrificing myself for you. I left my own people - those who understand my language. I left them to bring you the subtle melodies, the infinite nuances. In doing so, I seek difficulties, I shall be often rejected. You deal in terrible simplicities, in deserts, in primitive indifferentiation. You lack overtones. You lack the oblique, the indirect, the range, the virtuosity and
} 
Henry Miller foi o principal revisor de A casa do incesto, o que suscitou inúmeras discussões entre os escritores. Em uma carta, Miller explica que, em alguns momentos, achava que a língua em que Nin havia escrito A casa do incesto não era a língua inglesa e que o texto era um tanto quanto hermético e abstrato. A princípio, sua sugestão era de que Nin deveria ser mais explícita e dar algumas pistas ao leitor. Todavia, a autora se recusa a fazer qualquer alteração no texto e Miller é obrigado a rever seu ponto de vista:

Foi presunção da minha parte querer alterar a linguagem. Às vezes, a escrita não se assemelha ao inglês, mas ainda assim é uma linguagem e quanto mais você se aprofunda nela mais vital e necessária ela parece ser. O poema é uma violação da linguagem que corresponde à violação do pensamento e das emoções. Não poderia ter sido escrito em um inglês que qualquer escritor habilidoso emprega. Essa língua requer sua impressão íntima, à medida que alguém compreende e aprecia a sua pessoa é possível compreender e apreciar a língua estranha que você usa. Por esse motivo, achei difícil, depois que tinha ultrapassado certo ponto, fazer qualquer mudança radical no texto. Se o seu pensamento, em alguns momentos, é obscuro é somente porque o que você está tentando colocar em palavras desafia a linguagem (...). Acima de tudo, é a linguagem da modernidade, a linguagem dos nervos, das repressões, dos pensamentos larvais, dos processos inconscientes, das imagens não inteiramente divorciadas de seu conteúdo onírico, é a linguagem do neurótico, do pervertido (...). ${ }^{181}$

Na visão de Miller, o que estava por trás da cascata de imagens aparentemente confusas na primeira parte do poema, em que a narradora e Sabina se transformam em um único ser, era o desejo e o desespero de uma mulher que aos poucos se desfaz de todas as máscaras e se transforma em um ser andrógino autosuficiente. A narradora se torna a encarnação de uma força primitiva que se autofecunda: o princípio criador de onde tudo se origina. Ao ler o poema, escutamos ecos de mundos perdidos: da civilização Inca e da Atlântida. Uma música profana ressoa de cada palavra à medida que o texto se transforma no instrumento musical quena, feito de ossos humanos. Durante essa missa sacrílega, não há mais espaço para

maturity. Listen to me! I am your most intricate and variable musician. I can extend your ears, add hundreds of colors to your eyes, increase your palate's responsiveness, develop your senses.

${ }^{181}$ Miller, “About the Mona Pages”. In: STUHLMANN. Anaïs International Journal Volume 6, p. 94. It was presumptuous of me to want to alter the language. If it is not English sometimes it is a language nevertheless, and the farther one goes along with it the more vital and necessary it seems. It is a violation of language that corresponds with the violation of thought and feeling. It could not have been written in an English which every capable writer can employ. It required your intimate imprint, and in the measure that one understands and appreciates you one understands and appreciates the strange language you have used. That is why I found it difficult, after I had passed a certain point, to make any radical changes in the text. If your thoughts is occasionally obscure it is only because what you are trying to put into words defies language (...). Above all, it is the language of modernity, the language of nerves, repressions, larval thoughts, unconscious processes, images not entirely divorced from their dream content; it is the language of the neurotic, the perverted (...). 
aquilo que chamamos de lógica, para orquestrações artificiais, para monumentos filosóficos.

Este capítulo será dedicado à análise de alguns problemas de tradução e das soluções encontradas. Mas, antes de dar início às notas e aos comentários, gostaria de ressaltar alguns aspectos gerais da tradução. As imagens poéticas de A casa do incesto têm o poder de evocar determinados estados de espírito e sensações. E essa criação de imagens ocorre por meio da analogia. A linguagem analógica faz com que imagens de naturezas diferentes e opostas habitem o mesmo espaço.

O propósito dessa linguagem seria o de ampliar e transfigurar aquilo que chamamos e entendemos por realidade. E, por isso, a palavra mais empregada no texto para unir mundos distintos é a palavra like. É interessante notar que a língua portuguesa permite várias possibilidades de tradução para esta palavra: feito, como, tal, tal qual, parecer, semelhante, igual. Fiz uso de todas elas sendo que a sonoridade e a cadência da palavra na frase foi fator determinante na escolha.

Outra questão a se levar em conta na tradução de textos do inglês para o português é que a língua portuguesa permite a omissão de grande parte dos pronomes. Utilizei desta estratégia para manter a concisão e a economia da frase. No que diz respeito ao tempo da ação no poema, passado e presente se misturam. Em muitos momentos, a autora descreve a ação passada no presente e, para isso, utiliza-se do modo gerúndio, terminação -ing. Neste caso, a língua portuguesa permite tanto utilizar o verbo no tempo presente quanto o "a + infinitivo". Fiz uso de ambos. A última consideração a ser feita é que optei por fazer uso do pronome "tu" quando a narradora dialoga com outros personagens. A meu ver, o pronome "tu" estaria mais em harmonia com o tom em que o poema foi escrito.

Muitas foram as negociações que tive de realizar entre a língua inglesa e a portuguesa: ora de modo satisfatório, ora deixando a desejar. A lei das compensações, de certa maneira, oferece um consolo ao tradutor. Mas, para além de um estado melancólico que possa surgir da prática da tradução, o que realmente se destaca nessa atividade é sua riqueza e sua natureza extremamente desafiadora por instigar o intelecto, a sensibilidade e a intuição, além de colocar em movimento toda a bagagem cultural do tradutor. Sim, a tradução literária é mais do que necessária. A natureza errante e 
incompleta das línguas é o que permite que elas se confrontem. E o desejo de todo tradutor é que elas possam sair revitalizadas desse confronto.

\section{1 - NOTAS:}

1- My first vision of earth was water veiled / Minha primeira visão da terra foi através de um véu d'água.

Neste caso, não foi possível manter a concisão da frase e da imagem em português e tive que fazer uso de "através do".

2- I sway and float, stand on boneless toes listening for distant sounds / Balanço e flutuo na ponta sem ossos de meus pés, atenta a sons distantes.

Para manter uma melhor sonoridade e cadência da frase, optei traduzir "toes" “dedos" por ponta de pé, que é uma expressão comum em português "ficar na ponta dos pés" e preferi omitir o verbo "stand on". No caso do verbo "listening for", que significa escutar atentamente, a solução por mim encontrada foi "atenta." Sei que acabei deixando claro que o narrador é uma mulher apesar de no original este aspecto ainda não ser explícito, se bem que pelas fotomontagens que acompanham o livro ficamos sabendo na primeira página que se trata de uma mulher.

3- ...and walking with a swimming stride / e a caminhar como quem nada em longas braçadas.

A frase em inglês descreve dois tipos de movimento, caminhar e nadar, que são realizados simultaneamente e a palavra "stride" significa a passos largos. Sem dúvida, foi uma façanha transpor essa frase para o português. Prezei por manter a ideia de dois movimentos conjuntos e que desse uma ideia de extensão.

4- Ejected from a paradise of soundlessness / Expulsa de um paraíso de insondável silêncio.

A palavra "soundless" em inglês significa tanto sem som quanto insondável. Optei por deixar os dois sentidos em português. 
5- ...the heaviest portals slid open on smooth-oiled gongs and one entered the voicelessness of the dream. The terror and joy of murders accomplished in silence, in the silence of slidings and brushings. / os mais pesados portais abriam-se deslizando em silenciosos trilhos e entrava-se na mudez do sonho. $\mathrm{O}$ terror e a alegria de assassinatos cometidos em silêncio, no silêncio de afagos e carícias.

Optei por traduzir os adjectivos "smooth-oiled" como silencioso, tendo em mente seu efeito, neste caso, que o trilho deslize sem fazer barulho. Acho que a tradução literal "macio e oleoso" para qualificar o trilho não soaria bem em português. Já a tradução literal dos substantivos slidings and brushings seria impossível. Neste contexto, o sentido destas palavras está relacionado a uma forma de contato, de toques leves e suaves além de significar deslizar. Em português, encontrei alguns substantivos que expressassem essa ideia, como por exemplo, afago, carinho, carícia, toque. Optei pela sonoridade e pela imagem sensual de leveza que "afagos e carícias" evocam, a contrastar, na frase anterior, com a ideia brutal de assassinato.

6- None of them feeling their own weight / Ausência de peso.

Tenho evitado, sempre que possível, traduzir pronomes. "None of them" se refere a várias espécies de peixes citados na frase anterior e achei completamente dispensável em português. Preferi “ausência de peso" por sua concisão.

7- It was like yawning. I loved the ease and the blindness and the suave voyages on the water bearing one through obstacles. The water was there to bear one like a giant bosom / Era como bocejar. Adorava a tranquilidade e a cegueira e as mansas viagens na água a conduzir-me, com seus enormes braços, em meio a obstáculos.

Optei pela redução sintática por achar que a repetição do verbo "bear" fosse inflacionar a frase em português, além de mudar a imagem de "a giant bosom" para “enormes braços", que também transmite a ideia de acolhimento. "Um peito gigante" soaria cômico em português. Novamente, omiti os pronomes "one" na tradução. 
8- There were no currents of thoughts, only the caress of flow and desire mingling, touching, travelling, withdrawing, wandering - the endless bottoms of peace / Não havia correntes de pensamento, apenas a carícia do fluxo e do desejo se mesclando, roçando, avançando, recuando, vagueando - o fundo infindo da paz.

Em vez de traduzir o sentido literal de "travelling", "viajando", achei que "avançando" se adequaria melhor no conjunto das outras palavras citadas. A expressão "the endless bottoms of peace" foi traduzida como "o fundo infindo da paz", sendo que fiz uma leve mudança ao optar por "fundo" no singular e não como consta no original "bottoms", uma vez que a palavra fundos, em português, possui outro sentido.

9- From her nacreous skin perfumes spiralled like incense. Every gesture she made quickened the rhythm of the blood and aroused a beat chant like the beat of the heart of the desert, a chant which was the sound of her feet treading down into the blood the imprint of her face / De sua pele perolada, perfumes espiralavam qual incenso. Cada gesto seu acelerava o ritmo do sangue e incitava batidas feito o pulsar do coração do deserto, um canto que era o som de seus pés esmagando em seu sangue a marca de seu rosto.

No trecho "De sua pele perolada, perfumes espiralavam...", fui surpreendida por uma aliteração de forte teor poético que não consta no original. Na frase seguinte, omiti a palavra canto em "beat chant" por não encontrar algo correspondente em português, utilizando apenas a palavra "batidas". Já em "the beat of the heart of the desert", em português é possível usar "batida" ou "pulsar" para qualificar o movimento do coração. Achei que "pulsar" fosse mais apropriado no contexto desta frase.

10- Her necklace thrown around the world's neck, unmeltable. She carried it like a trophy wrung of groaning machinery, to match the inhuman rhythm of her march / Colar jogado em volta do pescoço do mundo, indissolúvel e que ela usava como se fosse um troféu extraído do gemido de uma máquina para igualar-se ao ritmo desumano de sua marcha.

"Groaning machine" foi traduzido como "gemido de uma máquina". O adjetivo "groaning" pode significar gemido, ronco, ranger, resmungar. Optei pela palavra 
"gemido", pela sua sonoridade. A repetição da vogal i nas palavras "extraído", "gemido", "máquina", "igualar-se" e "ritmo" confere uma certa cadência e pulso à frase.

11- The men she had embraced, and the women, all washing against the resonance of my memory / Os homens que ela tinha beijado, e as mulheres, avançando contra a ressonância de minha memória,

Custou-me a encontrar uma expressão em português para "washing against", cujo sentido está relacionado ao movimento forte da maré.

12- Deep into each other we turned our harlot eyes. She was an idol in Byzance, an idol dancing with legs parted / Olhávamos-nos de modo penetrante com olhos de meretriz. Ela era uma deusa em Bizâncio, uma deusa que dançava de pernas entreabertas.

Impossível uma tradução literal da primeira frase. Meu intuito foi manter o sentido, a poeticidade e a concisão em português. Na frase seguinte, utilizei a palavra "deusa" para "idol". Nos dias atuais, a palavra "ídolo" ganhou um significado diferente sendo muito empregada na mídia e no universo das celebridades. Seu sentido original remete à adoração de estátuas sagradas. Achei que a palavra "deusa" transmitisse melhor a ideia do sagrado.

13- The soft secret yielding of woman I carved into men's brains with copper words / Esculpi no cérebro dos homens, com palavras de cobre, a devoção suave e secreta da mulher.

Optei por fazer uma inversão sintática e iniciar a frase com o verbo por ser a forma mais natural em português. Muito me custou a tradução dos três adjetivos "soft secret yielding". A palavra “yielding" significa render-se, entregar-se totalmente, sem reservas. Sei que a palavra "devoção" foge um pouco do sentido exato de "yielding", mas foi a solução que encontrei que soasse bem junto à suave e secreto.

14- Fluted fingers. The house opened its green gate mouth and swallowed us / Dedos que são flautas. A casa abriu seu portão verde em forma de boca e nos engoliu. 
A questão da adjetivação em inglês é muito peculiar e difere bastante da adjetivação em português. Quase nunca é possível manter a concisão do inglês e as frases precisam ser reescritas em português. Em "fluted fingers" e "green gate mouth" traduzi como "dedos que são flautas" e "portão verde em forma de boca".

15- The keyhole had an ironic curve, like a question mark / a curva irônica do buraco da fechadura semelhante a um ponto de interrogação.

Ao traduzir esta frase, optei por fazer uma inversão, iniciando com "a curva irônica" e por omitir o verbo "had" com o intuito de obter uma frase mais concisa.

16- She was turning her serpent back to that alone which might overshadow her own stature giving her the joy of fecundation / revelaria sua serpente somente àquilo que pudesse cobrir de sombra seu corpo, dando a ela a alegria da fecundação.

O verbo "turning back" significa, dirigir-se a algo, voltar-se, expor, mostrar. Escolhi o verbo revelar por se encaixar perfeitamente no quadro de palavras citadas, além de trazer consigo uma forte carga poética e manter uma determinada cadência na frase junto às palavras serpente e somente.

17- Your beauty drowns me, drowns the core of me. When your beauty burns me I dissolve as I never dissolved before a man. From all men I was different, and myself, but I see in you that part of me which is you. I feel you in me; I feel my own voice becoming heavier, as If I were drinking you in... / Tua beleza me sufoca, sufoca o meu âmago. Tua beleza me queima e, então, dissolve-me como nunca me dissolvi diante de um homem. Sentia-me diferente de todos os homens e eu era eu mesma, mas em ti vejo algo de mim que és tu. Habitas meu corpo; embriago-me de ti e minha voz se adensa...

Diria que este foi o trecho mais difícil ao traduzir A casa do incesto. Há uma possibilidade de traduzi-lo literalmente, mas o texto em português cairia em um sentimentalismo que fugiria totalmente do tom do texto original. Por isso, optei por reescrevê-lo.

Essa foi apenas uma pequena amostra dos problemas por mim enfrentados ao traduzir o poema, o que deixa transparecer o quanto o exercício da tradução é 
complexo e desafiador. Nas páginas seguintes, encontra-se toda a tradução de $A$ casa do incesto e o texto original. 


\section{5 - TRADUÇÃO}

A Casa do Incesto

Tudo que sei está contido neste livro

escrito sem testemunha, edifício sem

dimensão, cidade suspensa no céu. 
House of Incest

All that I know is contained in this book

written without witness, an edifice without

dimension, a city hanging in the sky. 
Na manhã em que me levantei para dar início a este livro senti, enquanto tossia, algo saindo de minha garganta, a me estrangular. Cortei o fio que o prendia e o arranquei. Voltei para cama e disse: acabo de cuspir meu coração.

Existe um instrumento chamado quena feito de ossos humanos. Sua origem se deve à veneração de um índio por sua amada. Quando ela morreu, ele fez uma flauta de seus ossos. A quena tem um som mais penetrante e mais assombroso do que a flauta comum.

Aqueles que escrevem conhecem o processo. Foi o que pensei ao cuspir meu coração.

Apenas não espero até que meu amado morra. 
The morning I got up to begin this book I coughed. Something was coming out of my throat: it was strangling me. I broke the thread which held it and yanked it out. I went back to bed and said: I have just spat my heart.

There is an instrument called the quena made of human bones. It owes its origin to the worship of an Indian for his mistress. When she died he made a flute out of her bones. The quena has a more penetrating, more haunting sound than the ordinary flute.

Those who write know the process. I thought of it as I was spitting out my heart.

Only I do not wait for my love to die. 
Minha primeira visão da terra foi através de um véu d'água. Pertenço à raça de homens e mulheres que veem todas as coisas por uma cortina de mar, e meus olhos são da cor da água.

Olhava com olhos camaleônicos a face mutável do mundo, olhava com visão anônima meu ser incompleto.

Lembro-me do meu primeiro nascimento na água. Tudo em minha volta de uma transparência sulfurosa e meus ossos movendo-se como se feitos de borracha. Balanço e flutuo na ponta sem ossos de meus pés, atenta a sons distantes, sons que estão além do alcance de ouvidos humanos, enxergo o que está além do alcance de olhos humanos. Nasci repleta de memórias dos sinos da Atlântida. Sempre atenta a sons perdidos e à procura de perdidas cores, a permanecer para sempre na fronteira como alguém atormentado por memórias, e a caminhar como quem nada em longas braçadas. Corto o ar com barbatanas largas e afiadas e nado através de quartos sem paredes. Expulsa de um paraíso de insondável silêncio, catedrais ondulam a passagem de um corpo, como silenciosa música.

Esta Atlântida só poderia ser reencontrada à noite, na rota dos sonhos. Tão logo o sono cobria a rígida cidade nova, a rigidez do novo mundo, os mais pesados portais abriam-se deslizando em silenciosos trilhos e entrava-se na mudez do sonho. O terror e a alegria de assassinatos cometidos em silêncio, no silêncio de afagos e carícias. $\mathrm{O}$ lençol d'água sobre todas as coisas a sufocar a voz. E um monstro trouxe-me, por acaso, à superfície.

Perdida nas cores da Atlântida. Cores que se mesclam, sem fronteiras. Peixes de veludo, de organdi com dentes de renda, de tafetá com lantejoulas, de seda, de plumas, de vibrissas, com flancos laqueados e olhos de pedra de cristal, peixes de couro gasto com olhos de amora, olhos iguais ao branco do ovo. Flores que palpitam em hastes feito corações-do-mar. Nenhum deles ciente de seu próprio peso, o cavalo marinho se movendo tal qual uma pluma...

Era como bocejar. Adorava a tranquilidade e a cegueira e as mansas viagens na água a conduzir-me, com seus enormes braços, em meio a obstáculos. Havia sempre a água para repousar e a água transmitia as vidas e os amores, as palavras e os pensamentos. 
My vision on earth was water veiled. I am of the race of men and women who see all things through this curtain of sea, and my eyes are the color of water.

I looked with chameleon eyes upon the changing face of the world, looked with anonymous vision upon my uncompleted self.

I remember my first birth in water. All round me a sulphurous transparency and my bones move as if made of rubber. I sway and float, stand on boneless toes listening for distant sounds, sounds beyond the reach of human ears, see things beyond the reach of human eyes. Born full of memories of the bells of the Atlantide. Always listening for lost sounds and searching for lost colors, standing forever on the threshold like one troubled with memories, and walking with a swimming stride. I cut the air with wideslicing fins, and swim through wall-less rooms. Ejected from a paradise of soundlessness, cathedrals wavering at the passage of a body, like soundless music.

This Atlantide could be found again only at night, by the route of the dream. As soon as sleep covered the rigid new city, the rigidity of the new world, the heaviest portals slid open on smooth-oiled gongs and one entered the voicelessness of the dream. The terror and joy of murders accomplished in silence, in the silence of slidings and brushings. The blanket of water lying over all things stifling the voice. Only a monster brought me up on the surface by accident.

Lost in the colors of the Atlantide, the colors running into one another without frontiers. Fishes made of velvet, of organdie with lace fangs, made of spangled taffeta, of silks, and feathers and whiskers, with lacquered flanks and rock crystal eyes, fishes of withered leather with goose-berry eyes, eyes like the white of egg. Flowers palpitating on stalks like sea-hearts. None of them feeling their own weight, the seahorse moving like a feather...

It was like yawning. I loved the ease and the blindness and the suave voyages on the water bearing one through obstacles. The water was there to bear one like a giant bosom; there was always the water to rest on, and the water transmitted the lives and the loves, the words and the thoughts. 
Adormecia muito abaixo do nível das tempestades. Movia-me no interior da cor e da música como se dentro de um diamante marinho. Não havia correntes de pensamento, apenas a carícia do fluxo e do desejo se mesclando, roçando, avançando, recuando, vagueando - o fundo infindo da paz.

Não me lembro de ter sentido frio ou calor. Nenhuma dor provocada pelo frio ou pelo calor. A temperatura do sono, sem febre ou calafrio. Não me recordo de ter sentido fome. A comida passava lentamente por poros invisíveis. Não me lembro de ter chorado.

Sentia apenas a carícia de mover-me - mover-me para dentro de um outro corpo - absorvida e perdida dentro da carne de um outro, embalada pelo ritmo da água, pela palpitação lenta dos sentidos, pelo deslizar de seda.

Amando sem consciência, movendo-me sem esforço, na corrente macia de água e desejo, respirando num êxtase de dissolução.

Acordei ao raiar do dia, atirada sobre uma rocha, esqueleto de um navio sufocado em suas próprias velas. 
Far beneath the level of storms I slept. I moved within color and music as inside a sea-diamond. There were no currents of thoughts, only the caress of flow and desire mingling, touching, travelling, withdrawing, wandering - the endless bottoms of peace.

I do not remember being cold there, nor warm. No pain of cold and heat. The temperature of sleep, feverless and chilless. I do not remember being hungry. Food seeped through invisible pores. I do not remember weeping.

I felt only the caress of moving - moving into the body of another - absorbed and lost within the flesh of another, lulled by the rhythm of water, the slow palpitation of the senses, the movement of silk.

Loving without knowingness, moving without effort, in the soft current of water and desire, breathing in an ecstasy of dissolution.

I awoke at dawn, thrown up on a rock, the skeleton of a ship choked in its own sails. 
A noite me envolveu, uma fotografia despregada da moldura. $\mathrm{O}$ forro de um casaco rasgado como as duas conchas de uma ostra. O dia e a noite descolados um do outro, e eu entre eles, caindo, sem saber em que camada repousar, se na folha mais alta, fria e cinza da manhã ou na camada escura da noite.

O rosto de Sabina suspenso na escuridão do jardim. De seus olhos, uma tempestade de areia enrugava as folhas e revirava a terra; todas as coisas que até então tinham seguido um curso vertical agora giravam em círculos, em volta do rosto, em volta do rosto DELA. Olhava fixamente, olhar ancestral, séculos graves e luxuriantes a tremeluzir em profundas procissões. De sua pele perolada perfumes espiralavam qual incenso. Cada gesto acelerava o ritmo do sangue e incitava batidas como o pulsar do coração do deserto, um canto que era o som de seus pés esmagando em seu sangue a marca de seu rosto.

Uma voz que atravessava os séculos, tão densa que despedaçava o que tocava, tão densa que eu temia que fosse ressoar eternamente dentro de mim; uma voz enferrujada de obscenidades e gritos roucos que brotam do delta no último paroxismo do orgasmo.

A capa preta caía feito cabelos pretos dos ombros, meio presa, meio flutuando em volta do corpo. A teia do vestido sempre em movimento antes mesmo de ela se mover, como se estivesse consciente de seus impulsos, e ainda a agitar-se muito depois de parada, feito ondas recuando na maré baixa. As mangas penduradas como num suspiro, a barra do vestido dançando em torno dos pés.

Em sua garganta, um colar de aço reluzia como relâmpago, e o som do aço se assemelhava ao choque de duas espadas... Le pas d'acier... O aço do esqueleto de Nova York enterrado em granito, enterrado em pé. Le pas d'acier... notas marteladas no aço das cordas dos violões dos ciganos, no aço dos braços de cadeiras entorpecidas pelo seu hálito; o estrondo de cortinas de malha de aço caindo feito chuva de granizo, o estalido de barras e comportas de aço. Colar jogado em volta do pescoço do mundo, indissolúvel e que ela usava como se fosse um troféu extraído do gemido de uma máquina para igualar-se ao ritmo desumano de sua marcha. 
The night surrounded me, a photograph unglued from its frame. The lining of a coat ripped open like the two shells of an oyster. The day and night unglued, and I falling in between not knowing on which layer I was resting, whether it was the cold grey upper leaf of dawn, or the dark layer of night.

Sabina's face was suspended in the darkness of the garden. From the eyes a simoun wind shriveled the leaves and turned the earth over; all things which had run a vertical course now turned in circles, round the face, around HER face. She stared with such an ancient stare, heavy luxuriant centuries flickering in deep processions. From her nacreous skin perfumes spiraled like incense. Every gesture she made quickened the rhythm of the blood and aroused a beat chant like the beat of the heart of the desert, a chant which was the sound of her feet treading down into the blood the imprint of her face.

A voice that had traversed the centuries, so heavy it broke what it touched, so heavy I feared it would ring in me with eternal resonance; a voice rusty with the sound of curses and the hoarse cries that issue from the delta in the last paroxysm of orgasm.

Her black cape hung like black hair from her shoulders, half-draped, half floating around her body. The web of her dress moving always a moment before she moved, as if aware of her impulses, and stirring long after she was still, like waves ebbing back to the sea. Her sleeves dropped like a sigh and the hem of her dress danced around her feet.

The steel necklace on her throat flashed like summer lightning and the sound of the steel was like the clashing of swords...Le pas d'acier...The steel of New York's skeleton buried in granite, buried standing up. Le pas d'acier...notes hammered on the steel-stringed guitars of the gypsies, on the steel arms of chairs dulled with her breath; steel mail curtains falling like the flail of hail, steel bars and steel barrage cracking. Her necklace thrown around the world's neck, unmeltable. She carried it like a trophy wrung of groaning machinery, to match the inhuman rhythm of her march. 
A folha de outono de suas palavras, os matizes do vitral de seu humor, a ferrugem na voz, a fumaça na boca, seu hálito na minha visão, como hálito humano embaçando o espelho.

Palavras - meias-palavras, frases que não precisavam ser terminadas, abstrações, sinos chineses tocados com badalos envoltos em algodão, imitações de flores de laranjeira pintadas em porcelana. Meias-palavras próximas, abafadas, das mulheres de carne macia. Os homens que ela beijara, e as mulheres, avançando contra a ressonância de minha memória. Som dentro do som, cena dentro da cena, mulher dentro da mulher como ácido revelando um roteiro invisível. Uma mulher eternamente dentro da outra, em longa procissão, estilhaçando minha mente em fragmentos, em quartos de tom e que nenhuma batuta de orquestra conseguirá jamais reconstituir.

A luminosa máscara de cera do seu rosto, imóvel, olhos de sentinela. A observar meu caminhar sibarítico, e eu, a sibilância da sua língua. Olhávamo-nos de modo penetrante com olhos de meretriz. Ela era uma deusa em Bizâncio, uma deusa que dançava de pernas entreabertas; e eu escrevia com pólen e mel. Esculpi no cérebro dos homens, com palavras de cobre, a devoção suave e secreta da mulher; tatuei a imagem de Sabina em seus olhos. Eles foram consumidos pela febre das suas próprias entranhas, o veneno indissolúvel das lendas. Se a torrente fracassou em afogá-los, ou se eles conseguiram se salvar, eu prossigo assombrando suas memórias com estórias que gostariam de esquecer. Tudo que havia de ágil e malevolente numa mulher poderia ser impiedosamente destruído, mas quem destruiria a ilusão em que eu a punha para dormir toda noite? Vivíamos em Bizâncio. Sabina e eu, até que as pedras preciosas em nossa fronte sangraram nossos corações, até que nossos corpos se cansaram do peso de brocados, até que nossas narinas se queimaram com a fumaça de perfumes, e quando havíamos passado para outros séculos, eles nos prenderam em molduras de cobre. Os homens sempre a reconheciam: o mesmo rosto radiante, a mesma voz enferrujada. E eu e ela nos reconhecíamos; eu, seu rosto; e ela, minha lenda.

Ela pôs em meu pulso um bracelete de aço polido e o meu pulso batia segundo sua vontade, perdendo a cadência humana, pulsando freneticamente feito um selvagem em frenesi orgiástico. O lamento de flautas, o duplo canto do vento através de nossos frágeis ossos, a recordação longínqua do estalar de ossos em leitos de pluma, quando a veneração que inspirávamos transformava-se em luxúria. 
The leaf fall of her words, the stained glass hues of her moods, the rust in her voice, the smoke in her mouth, her breath on my vision like human breath blinding a mirror.

Talk - half-talk, phrases that had no need to be finished, abstraction, Chinese bells played on with cotton-tipped sticks, mock orange blossoms painted on porcelain. The muffled, close, half- talk of soft-fleshed women. The man she had embrace, and the women, all washing against the resonance of my memory. Sound within sound, scene within scene, woman within woman - like acid revealing an invisible script. One woman within another eternally, in a far-reaching procession, shattering my mind into fragments, into quarters tones which no orchestral baton can ever make whole again.

The luminous mask of her face, waxy, immobile, with eyes like sentinels. Watching my sybaritic walk, and I the sibilance of her tongue. Deep into each other we turned our harlot eyes. She was an idol in Byzance, an idol dancing with legs parted; and I wrote with pollen and honey. The soft secret yielding of woman I carved into men's brains with copper words; her image I tattooed in their eyes. They were consumed by the fever of their entrails, the indissoluble poison of legends. If the torrent failed to engulf them, or they did extricate themselves, I haunted their memory with the tale they wished to forget. All that was swift and malevolent in woman might be ruthlessly destroyed, but who would destroy the illusion on which I laid her to sleep each night? We lived in Byzance. Sabina and I, until our hearts bled from the precious stones on our foreheads, our bodies tired of the weight of brocades, our nostrils burned with the smoke of perfumes; and when we passed into other centuries they enclosed us in copper frames. Men recognize her always: the same effulgent face, the same rust voice. And she and I, we recognize each other, I her face and she my legend.

Around my pulse she put a flat steel bracelet and my pulse beat as she willed, losing its human cadence, thumping like a savage in orgiastic frenzy. The lamentations of flutes, the double chant of wind through our slender bones, the cracking of our bones distantly remembered when on beds of down the worship we inspired turned to lust. 
Enquanto caminhávamos, foguetes disparavam das luzes das ruas. Num rugido selvagem engolíamos a rua e as casas com seus olhos fechados e cílios de gerânios; engolíamos postes de telégrafo tremulando de mensagens; engolíamos gatos perdidos, árvores, morros, cercas vivas, o sorriso labiríntico de Sabina no buraco da fechadura. A porta a gemer, a abrir. O sorriso cerrado de Sabina. Um rouxinol a desfolhar melífera madressilva. Mel sugado. Dedos que são flautas. A casa abriu seu portão verde em forma de boca e nos engoliu. A cama flutuava.

O disco estava arranhado, o canto despedaçou-se e seus estilhaços cortavam nossos pés. Era manhã e ela estava perdida. Pus as casas de volta no lugar, alinhei os postes ao longo do rio e os gatos perdidos que pulavam pela rua. Pus de volta os morros. A rua saiu da minha boca qual fita de veludo - e permaneceu ali feito serpentina. As casas abriram seus olhos. A curva irônica do buraco da fechadura semelhante a um ponto de interrogação. A boca de uma mulher.

Trazia comigo os fetiches de Sabina, suas marionetes, suas cartas de ler a sorte gastas nas pontas como a crista de uma onda. As janelas da cidade estavam manchadas e estilhaçadas pela luz da chuva e pelo sangue que ela retirava de mim a cada mentira, a cada desilusão. Por baixo da pele de seu rosto eu entrevia cinzas: será que ela morreria antes de estarmos juntas em pérfida união? Olhos, mãos, sentidos que somente as mulheres têm.

Não há escárnio entre mulheres. Deita-se em paz como se no próprio peito.

Sabina já não mais beijava homens e mulheres. Na febre da sua inquietude o mundo perdia a forma humana. Ela estava perdendo o poder humano de fazer com que um corpo se encaixasse noutro corpo em completude humana. Estava delimitando os horizontes, afundando-se em planetas sem eixo, perdendo sua polaridade e seu conhecimento divino de união, de fusão. Deixava-se espalhar como a noite no universo e não encontrava nenhum deus com quem se deitar. A outra metade pertencia ao sol, e ela estava em guerra com o sol e a luz. Não iria tolerar nenhum feixe de luz em livros abertos, nenhuma orquestração de ideias costurada por um único tema, não seria coberta pelo sol, e metade do universo pertencia a ele; revelaria sua serpente somente àquilo que pudesse cobrir seu corpo de sombra, dando a ela a alegria da fecundação. 
As we walked along, rockets burst from the streets lamps; we swallow the asphalt road with a jungle roar and the houses with their closed eyes and geranium eyelashes; swallowed the telegraph poles trembling with messages; swallowed stray cats, trees, hills, hedges, Sabina's labyrinthian smile on the keyhole. The door moaning, opening. Her smile closed. A nightingale disleafing melliferous honeysuckled. Honeysuckled. Fluted fingers. The house opened its green gate mouth and swallowed us. The bed was floating.

The record was scratched, the crooning broken. The pieces cut our feet. It was dawn and she was lost. I put back the houses on the road, aligned the telegraphs poles along the river and the stray cats jumping across the road. I put back the hills. The road came out of my mouth like a velvet ribbon - it lay there serpentine. The houses opened their eyes. The keyhole had an ironic curve, like a question mark. The woman's mouth.

I was carrying her fetiches, her marionettes, her fortune teller's card worn at the corners like the edge of a wave. The window of the city were stained and splintered with rainlight and the blood she drew from me with each lie, each deception. Beneath the skin of her cheeks I saw ashes: would she die before we had joined in perfidious union? The eyes, the hands, the sense that only women have.

There is no mockery between women. One lies down at peace as on one's breast.

Sabina was no longer embracing men and women. Within the fever of her restlessness the world was losing its human power to fit body to body in human completeness. She was delimiting the horizons, sinking into planets without axis, losing her polarity and the divine knowledge of integration, of fusion. She was spreading herself like the night over the universe and found no god to lie with. The other half belonged to the sun, and she was at war with the sun and light. She would tolerate no bars of light on open books, no orchestration of ideas knitted by a single theme; she would not be covered by the sun, and half the universe belonged to him; she was turning her serpent back to that alone which might overshadow her own stature giving her the joy of fecundation. 
Vem comigo Sabina, vem para minha ilha. Vem para minha ilha de pimentões vermelhos que estalam sobre lentos braseros, de potes mouros de barro que guardam água dourada, de palmeiras, brigas de gatos selvagens, gemidos de um burro ao amanhecer, os pés nos recifes de coral e anêmonas marinhas, o corpo coberto por longas algas, o cabelo de Melisande sobre a sacada da Opéra Comique, inexorável diamantina luz solar, densas horas mansas em sombras violáceas, rochas cinzentas e oliveiras, limoeiros e seus frutos pendurados feito lanternas em uma festa ao ar livre, brotos de bambu em constante balanço, som macio de alpercatas, romãs jorrando sangue, canto mouro semelhante ao som de flauta, demorado e insistente, de homens que aram a terra, praguejando, entoando, maldizendo, derramando suor junto às sementes.

Tua beleza me sufoca, sufoca meu âmago. Tua beleza me queima e, então, dissolvo-me como nunca me dissolvi diante de um homem. Sentia-me diferente de todos os homens e eu era eu mesma, mas em ti vejo algo de mim que és tu. Habitas meu corpo; embriago-me de ti e minha voz se adensa, cada delicado fio de semelhança sendo soldado e já não mais se detecta fissuras.

Tuas mentiras não são mentiras, Sabina. Elas são flechas atiradas de tua órbita pela força de tua fantasia. Para alimentar a ilusão. Para destruir a realidade. Faço-te um favor: inventarei tuas mentiras e com elas atravessaremos o mundo. Mas no rastro de nossas mentiras desenrolo o fio dourado de Ariadne - para refazer o caminho de volta, para retornar à fonte e dormir uma noite ao ano livre de todas as superestruturas.

Sabina, deixaste tua marca no mundo. Eu apenas o atravessei como um fantasma. Será que alguém repara na coruja que está na árvore à noite, no morcego que bate contra o vidro da janela enquanto os outros conversam, nos olhos que refletem como espelho d'água e sugam como mata-borrão, na piedade que tremeluz serenamente como luz de vela, na compreensão na qual as pessoas adormecem?

\section{SERÁ QUE ALGUÉM SABE QUEM EU SOU?}

Até mesmo a minha voz veio de outros mundos. Fui embalsamada em minhas mais secretas vertigens. Estive suspensa sobre o mundo pensando qual caminho seguir sem que tivesse que pisar na terra ou na relva. Meus passos eram sensíveis e a mera crepitação de pedras poderia aprisioná-los. 
Come away with me, Sabina, come to my island. Come to my island of red peppers sizzling over slow braseros, Moorish earthen jars catching the gold water, palm trees, wild cats fighting, at dawn a donkey sobbing, feet on the coral reefs and seaanemones, the body covered with long seaweeds, Melisande's hair hanging over the balcony at the Opéra Comique, inexorable diamond sunlight, heavy nerveless hours in the violaceous shadows, ash-colored rocks and olive trees, lemon trees with lemons hung like lanterns at a garden party, bamboo shoots forever trembling, soft-sounding espadrilles, pomegranates spurting blood, a flute-like Moorish chant, long and insistent, of the ploughmen, trilling, swearing, trilling and cursing, dropping perspiration on the earth with the seeds.

Your beauty drowns me, drowns the core of me. When your beauty burns me I dissolve as I never dissolved before man. From all men I was different, and myself, but I see in you that part of me which is you. I feel you in me, I feel my own voice becoming heavier, as If I were drinking you in, every delicate thread of resemblance being soldered by fire and one no longer detects the fissure.

Your lies are not lies, Sabina. They are arrows flung out of your orbit by the strength of your fantasy. To nourish illusion. To destroy reality. I will help you: it is I who will invent lies for you and with them we will traverse the world. But behind our lies I am dropping Ariadne's golden thread - to retrace one's lies, to return to the source and sleep one night a year washed of all superstructures.

Sabina, you made your impression upon the world. I passed through it like a ghost. Does anyone notice the owl in the tree at night, the bat which strikes the window pane while others are talking, the eyes which reflect like water and drink like blotting paper, the pity which flickers quietly like candlelight, the understanding on which people lay themselves to sleep?

\section{DOES ANYONE KNOW WHO I AM?}

Even my voice came from other worlds. I was embalmed in my own secret vertigoes. I was suspended over the world, seeing what road I could tread without treading down even clay or grass. My step was a sentient step; the mere crepitation of gravel could arrest my walk. 
Quando te vi, Sabina, escolhi meu corpo.

Deixarei que me carregues à fecundidade da destruição. E, então, poderei escolher um corpo, um rosto e uma voz. Transformo-me em ti. E tu te tornas aquilo que sou. Silencia a corrente exuberante dos sentidos do teu corpo e verás em mim, intactos, teus próprios medos e lamentos. Verás o amor separado das paixões a ti concedidas e eu verei as paixões despojadas de amor. Abandona o papel que encenas e descansa no centro de teus verdadeiros desejos. Suspende, por um momento, teus violentos desatinos. Renuncia à tensão furiosa e indomável.

Eu me encarregarei de todas essas tarefas.

Para de tremer, de te agitar, de ofegar, de amaldiçoar e reencontra tua essência, que sou eu. Descansa dos desvios, das distorções e das deformações. Por uma hora tu serás eu, ou melhor, a tua outra metade. A metade que tu perdeste. Tudo o que queimaste, quebraste e rasgaste ainda encontra-se em minhas mãos. Eu sou a guardiã de coisas frágeis e de ti, guardei aquilo que é indissolúvel.

Nem mesmo a terra e o sol podem mostrar suas duas faces de uma única vez. Agora, estamos inextricavelmente entrelaçadas. Juntei todos os fragmentos e os devolvo a ti. Correste com o vento, desintegrando-te e dissolvendo-te. Eu corri atrás de ti feito tua própria sombra, recolhendo o que semeaste em baús insondáveis.

\section{EU SOU TUA OUTRA FACE}

Nossas faces soldadas pela leveza de nossos cabelos, fundidas, deixando entrever dois perfis de uma mesma alma. Mesmo quando eu atravessava uma sala feito um sopro, trazia inquietude às outras pessoas e elas tinham consciência de que era eu que havia passado.

Eu era a chama branca de teu hálito, teu hálito sufocante, a definhar o mundo. Assumi tua imagem e através de ti deixei minha marca no mundo. Glorifiquei minha própria chama em ti.

ESTE É O LIVRO QUE ESCREVESTE

E TU ÉS A MULHER

QUE EU SOU 
When I saw you, Sabina, I chose my body.

I let you carry me into the fecundity of destruction. I choose a body then, a face, a voice. I become you. And you become me. Silence the sensational course of your body and you will see in me, intact, your own fears, your own pities. You will see love which was excluded from the passions given you, and I will see the passions excluded from love. Step out of your role and rest yourself on the core of your true desires. Cease for a moment your violent deviations. Relinquish the furious indomitable strain.

I will take them up.

Cease trembling and shaking and gasping and cursing and find again your core which I am. Rest from twistedness, distortion, deformations. For an hour you will be me; that is, the other half of yourself. The half you lost. What you burnt, broke, and tore is still in my hands: I am the keeper of fragile things and I have kept of you what is indissoluble.

Even the world and the sun cannot show their two faces at once.

So now we are inextricably woven. I have gathered together all the fragments. I return them to you. You have run with the wind, scattering and dissolving. I have run behind you, like your own shadow, gathering what you have sown in deep coffers.

\section{AM THE OTHER FACE OF YOU}

Our faces are soldered together, showing two profiles of the same soul. Even when I passed through a room like a breath, I made others uneasy and they knew I had passed.

I was the white flame of your breath, your simoun breath shriveling the world. I borrowed your visibility and it was through you I made my imprint on the world. I praised my own flame in you.

\section{THIS IS THE BOOK YOU WROTE}

AND YOU ARE THE WOMAN

I AM 
Só que nossas faces têm que brilhar duplamente - como o dia e a noite - sempre separadas pelo espaço e as evoluções do tempo.

A fumaça lançou minha cabeça ao teto onde paira, mirando olhos de sapo, cabelo de palha, boca de couro curtido, cabeças calvas refletidas no espelho, mãos peludas de macaco de palmas cor-de-rosa. A música açoita o passado para fora de seu túmulo e múmias flagelam minha memória.

E se Sabrina não passasse agora de uma mera lembrança; E se eu tivesse que ficar aqui sentada e ela nunca mais retornasse! E se eu a tivesse imaginado numa noite em que o ópio fizera sutis incisões e dispusera as camadas do meu corpo sobre redes de seda persas e envolvera em algodão cada um dos meus nervos e atirara flechas radioativas de fantasia em minha carne...

Estou congelando e minha cabeça retorna ao chão por uma fina película de fumaça. E, mais uma vez, com angústia profunda, procuro por Sabina em meio à multidão sem rosto.

A insistência das imagens, reflexos em espelhos trincados, faz com que eu adoeça. Sou uma mulher com olhos de gato siamês, sempre sorrindo por detrás de minhas palavras graves, zombando de minha própria intensidade. Sorrio porque eu escuto o OUTRO e acredito no OUTRO. Sou uma marionete manuseada por dedos inexperientes, despedaçada, que se move sem harmonia, um braço morto e o outro a remexer no vazio. Rio, não quando o riso se encaixa à minha fala, mas quando ele se ajusta às correntes subterrâneas de minha fala. Quero saber o que corre nas profundezas, o que corre naquilo que é pontuado por amargas convulsões. As duas correntes não se encontram. Vejo em mim duas mulheres grotescamente unidas como gêmeos de circo. Vejo-as tentando se desvencilhar uma da outra. Escuto o dilaceramento, a raiva e o amor, a paixão e a piedade. Quando o ato de deslocamento subitamente cessa - ou quando deixo de ter consciência do ruído - então o silêncio é mais terrível porque não há senão insanidade à minha volta, insanidade de coisas que estão sendo arrancadas dentro de meu ser, raízes que se desentranham para crescerem separadamente, esforço feito para alcançar a unidade.

Um compasso basta para aquietar o laceramento por um instante; mas eis que o sorriso se insinua novamente e sinto que saltamos para além de qualquer possibilidade de coesão. 
Only our faces must shine twofold - like day and night - always separated by space and the evolutions of time.

The smoke sent my head to the ceiling: there it hung, looking down upon frog eyes, straw hair, mouth of soiled leather, mirrors of bald heads, furred monkey hands with ham-colored palms. The music whipped the past out of its tomb and mummies flagellated my memory.

If Sabina were now a memory; if I should sit here and she should never come again! If only I imagined her one night because the drug made fine incisions and arranged the layers of my body on Persian silk hammocks, tipped with cotton each fine nerve and sent the radium arrows of fantasy through the flesh.

I am freezing and my head falls down through a thin film of smoke. I am searching for Sabina again with deep anguish through the faceless crowd.

I am ill with the obstinacy of images, reflections in cracked mirrors. I am a woman with Siamese cat eyes smiling always behind my gravest words, mocking my own intensity. I smile because I listen to the OTHER and I believe the OTHER. I am a marionette pulled by unskilled fingers, pulled apart, inharmoniously dislocated; one arm dead, the other rhapsodizing in mid-air. I laugh, not when it fits into my talk, but when it fits into the undercurrents of my talk. I want to know what is running underneath thus punctuated by bitter upheavals. The two currents do not meet. I see two women in me freakishly bound together, like circus twins. I see them tearing away from each other. I can hear the tearing, the anger and love, passion and pity. When the act of dislocation suddenly ceases - or when I cease to be aware of the sound - then the silence is more terrible because there is nothing but insanity around me, the insanity of things pulling, pulling within oneself, the roots tearing at each other to grow separately, the strain made to achieve unity.

It requires only a bar of music to still the dislocation for a moment; but there comes the smile again, and I know that the two of us have leaped beyond cohesion. 
O cinza não é mero cinza, mas sim um vasto telhado de chumbo que cobre o mundo como uma tampa de caldeirão de sopa. O hálito dos seres humanos se assemelha ao vapor que sai de uma lavanderia. A fumaça dos cigarros tal qual uma chuva de cinzas do Vesúvio. Luzes com gosto de enxofre, e cada rosto te observa obstinadamente com a imensidão dos seus próprios defeitos. O quarto de tão minúsculo parece uma jaula de ferro onde é impossível sentar-se ou deitar-se. A vastidão de outros quartos é raiva mortal sempre suspensa sobre a cabeça, à espera do momento em que a tua alegria irá te deixar. Riso e lágrimas não são experiências separadas, com intervalos de descanso: juntos te arrastam e é como andar com uma espada entre as pernas. A chuva não molha o cabelo, mas fica pingando nas células do cérebro com a persistência de uma goteira. A neve não congela as mãos, mas, como o éter, distende os pulmões até explodirem. Todos os navios estão a afundar com suas entranhas em chamas e o fogo sibila no porão de cada casa. A carne mais branca do ser amado será cortada pelo vidro e esmagada pela roda. Os longos uivos na noite são uivos de morte. A noite é aliada dos torturadores. O dia é a luz lançada sobre descobertas dilacerantes. Se um cão ladra é porque o homem que aprecia feridas abertas salta pela janela. $\mathrm{O}$ riso precede a histeria. Estou à espera da violenta queda e da espuma na boca.

Um quarto cujo teto me ameaça como uma tesoura aberta. Janelas de sótão. Deito-me na cama como se fosse pedra. Todos os contatos se rompem. Lentamente, me despeço de cada ser amado, lentamente, cuidadosamente, completamente. Digo-lhes o que lhes devo e o que me devem. Guardo comigo seus últimos olhares e o último orgasmo. Minha casa está vazia, inundada de sol, viva de reflexos, sua quietude repleta de implicações, imagens secretas que qualquer dia me enlouquecerão tão logo eu me ponha diante de paredes nuas, ouço mais do que é permitido, enxergo mais do que é humanamente tolerável. Despeço-me de todos. Morro num quarto minúsculo e arqueado em forma de tesoura, sem meus amores e meus pertences e sem ao menos constar no livro de registro do hotel. Ao mesmo tempo, sei que se ficasse neste quarto por alguns dias poderia começar uma vida inteiramente nova - como se a carne humana houvesse sido soldada após uma cirurgia. Mais que o terror da morte, é o terror desta nova vida que me excita. Salto da cama e fujo deste quarto que cresce em torno de mim como uma teia envenenada, tentando se apossar de minha imaginação, corroendo minha memória de modo que em sete segundos terei esquecido quem sou e quem amei. 
Greyness is no ordinary greyness, but a vast lead roof which covers the world like the lid of a soup pan. The breath of human beings is like the steam of a laundry house. The smoke of cigarettes is like a rain of ashes from Vesuvius. The light taste of sulphur, and each face stares at you with the immensity of its defects. The smallness of a room is like that of an iron cage in which one can neither sit not lie down. The largeness of other rooms is like a mortal anger always suspended above you, awaiting the moment of your joy to fall. Laughter and tears are not separate experiences, with intervals of rest: they rush out together and it is like walking with a sword between your legs. Rain does not wet your hair but drips in the cells of the brain with the obstinacy of a leak. Snow does not freeze the hands, but like ether distends the lungs until they burst. All the ships are sinking with fire in their bowels, and there are fires hissing in the cellars of every house. The loved one's whitest flesh is what the broken glass will cut and the wheel crush. The long howls in the night are howls of death. Night is the collaborator of tortures. Day is the light on harrowing discoveries. If a dog barks it is the man who loves wide gashes leaping in through the window. Laughter precedes hysteria. I am waiting for the heavy fall and the foam at the mouth.

A room with a ceiling threatening me like a pair of open scissors. Attic windows. I lie on a bed like gravel. All connections are breaking. Slowly I part from each being I love, slowly, carefully, completely. I tell them what I owe them and what they owe me. I cull their last glances and the last orgasm. My house is empty, sunglazed, reflectively alive, its stillness gathering implications, secret images which someday will madden me when I stand before blank walls, hearing far too much and seeing more than is humanly bearable. I part from them all. I die in a small scissorarched room, dispossessed of my loves and my belongings, not even registered in the hotel book. At the same time I know that if I stayed in this room a few days an entirely new life could begin - like the soldering of human flesh after an operation. It is the terror of this new life, more than the terror of dying, which arouses me. I jump out of bed and run out of this room growing around me like a poisoned web, seizing my imagination, gnawing into my memory so that in seven moments I will forget who I am and whom I have loved. 
Foi no quarto número 35 onde, na manhã seguinte, eu poderia ter acordado louca ou prostituta.

O desejo distendido rompeu os nervos, e cada nervo parecia romper-se um por um, continuamente, fazendo incisões e o ácido circulando ao invés do sangue. Contorço-me dentro da minha própria vida, à procura de uma saída para carregar todos os gritos fundidos e derreter toda a dor em um caldeirão de palavras onde todos pudessem mergulhar, todos aqueles que buscam palavras para seu próprio sofrimento. Agora eu mexo um enorme caldeirão; e alimento as pessoas com enormes porções de ácido, palavras amargas o bastante para queimar toda a amargura.

Rompa a crosta marrom da terra e o mar irá subir, anêmonas-do-mar flutuarão sobre meu leito, e os navios mortos terminarão suas viagens em meu jardim. Exorcize os demônios que marcam as horas em minha cabeça à noite quando toda contagem deveria ser suspensa. Eles marcam as horas porque sabem que, em meus sonhos, lhes roubo séculos inteiros. Uma hora apenas deve ser contada contra mim.

Ouvi os alaúdes trazidos da Arábia e senti em meus seios correntes de fogo líquido que correm pelos quartos da Alhambra e me revigoram de águas demasiadamente cristalinas.

A imensa dor translúcida do amor dividido, amor dividido...

Encontrava-me em um navio de safira e navegava em mares de coral. E cantava na proa. Meu canto insuflava e rasgava as velas; na borda do rasgado havia sinal de queimado e minha voz, também, despedaçava nuvens.

Avistei uma cidade onde cada casa se erguia numa rocha entre mares negros repletos de serpentes violetas sibilando espanto, lambendo as pedras e espiando com olhos esbugalhados os jardins por cima do muro.

Vi a palmeira de vidro balançar diante de meus olhos; na minha ilha, as palmeiras eram estáticas e empoeiradas, entorpecidas de tanta dor. Folhas verdes murchavam por mim, e todas as árvores pareciam vitreamente apáticas, apenas a palmeira de vidro deixara crescer uma folha nova, em seu ponto mais alto, no clímax de sua cabeça. 
It was room number 35 in which I might have awakened next morning mad or a whore.

Desire which had stretched the nerve broke, and each nerve seemed to break separately, continuously, making incisions, and acid ran instead of blood. I writhed within my own life, seeking a free avenue to carry the molten cries, to melt the pain into a cauldron of words for everyone to dip into, everyone who sought words for their own pain. What an enormous cauldron I stir now; enormous mouthfuls of acid I feed the others now, words bitter enough to burn all bitterness.

Disrupt the brown crust of the earth and all the sea will rise; the sea-anemones will float over my bed, and the dead ships will end their voyages in my garden. Exorcise the demons who ring the hours over my head at night when all counting should be suspended; they ring because they know that in my dreams I am cheating them of centuries. It must be counted like an hour against me.

I heard the lutes which were brought from Arabia and felt in my breasts the currents of liquid fire which run through the rooms of the Alhambra and refresh me from the too clears waters.

The too clear pain of love divided, love divided...

I was in a ship of sapphire sailing on seas of coral. And standing at the prow singing. My singing swelled the sails and ripped them; where they had been ripped the edge was burnt and the clouds too were ripped to tatters by my voice.

I saw a city where each house stood on a rock between black seas full of purple serpents hissing alarms, licking the rocks and peering over the walls of their gardens with bulbous eyes.

I saw the glass palm tree sway before my eyes; the palm trees on my island were still and dusty when I saw them deadened by pain. Green leaves withered for me, and all the trees seemed glassily unresponsive while the glass palm tree threw off a new leaf on the very tip and climax of its head. 
Da casa branca brotou uma trilha branca cercada de cactos eriçados de longos dedos peludos, imóveis ao vento e indiferentes aos anos. Por sobre os cactos que jamais envelheciam, brotos de bambu tremiam lado a lado, perpetuamente em movimento com o vento.

A casa era em forma de ovo, o chão coberto de algodão e não havia janelas, dormia-se em plumas e através da concha ouvia-se o som do realejo e o vendedor de maçãs que não conseguia encontrar a campainha.

Imagens - trazendo consigo a dissolução da alma dentro do corpo como se fosse a ruptura do ácido-doce do orgasmo. Imagens aceleravam a circulação do sangue e a vigilância da mente que tenta se proteger de perigosos êxtases agora se torna inútil. A realidade se afogara e a fantasia sufocava todas as horas do dia.

Hoje nada parece real a não ser a morte do peixe dourado que costumava fazer amor na piscina a noventa quilômetros por hora. A empregada deu a ele um enterro cristão. Aos vermes! Aos vermes! 
The white path sprouted from the heart of the white house and was edged with bristly cactus long-fingered and furry, unmoved by the wind, ageless. Over the ageless cactus the bamboo shoots trembled, close together, perpetually wind-stirred.

The house had the shape of an egg, and it was carpeted with cotton and windowless; one slept in the down and heard through the shell the street organ and the apple vendor who could not find the bell.

Images - bringing a dissolution of the soul within the body like the rupture of sweet-acid of the orgasm. Images made the blood run back and forth, and the watchfulness of the mind watching against dangerous ecstasies was now useless. Reality was drowned and fantasies choked each hour of the day.

Nothing seems true today except the death of the goldfish who used to make love at ninety kilometers an hour in the pool. The maid has given him a Christian burial. To the worms! To the worms! 
Flutuo novamente. Todos os fatos e todas as palavras, todas as imagens, todos os presságios me devastam e zombam entre si. O sonho! O sonho! O sonho ressoa em mim como um imenso sino de cobre sempre que desejo traí-lo. O sonho me roça inteira com suas asas de morcego sempre que abro os olhos humanos e procuro viver fora de seu domínio. Sempre que a dor humana me atinge de forma violenta, sempre que sou corroída pela raiva, ressuscito, sempre ressuscito após a crucificação e tenho pavor de minhas ascensões. A FENDA NA REALIDADE. A fuga divina. Caio. Caio nas trevas depois da colisão com a dor e, depois da dor, a fuga divina.

Oh, o peso, o peso terrível da minha cabeça sendo puxada pelas nuvens, a balançar no espaço, o corpo feito um feixe de palha, as nuvens puxando meu cabelo como um cachecol preso a uma roda de carruagem, o corpo pendurado, colidindo com estrelas-lanternas, nuvens que me arrastam sobre o mundo.

Não consigo parar nem descer.

Ouço o desenrolar de água, de céus e cortinas. Ouço o tremer das folhas, a respiração do ar, o gemido dos que ainda não nasceram, a pressão do vento.

Ouço os movimentos das estrelas e dos planetas, o leve ruído de ferrugem quando mudam de posição. A passagem sedosa de radiações, a respiração de círculos girando.

Ouço a passagem de mistérios e a respiração de monstros. Sobretons apenas, ou semitons. O choque com a realidade turva minha visão e me encontro submersa no sonho. Sinto a distância como uma ferida. A distância se desenrola à minha frente como um tapete diante dos degraus de uma catedral que se enfeita para um casamento ou um funeral. Desenrolou-se como uma noiva de vermelho entre mim e os outros, mas eu não consigo percorrê-la sem uma sensação de inquietação, igual ao que se sente em cerimônias. A cerimônia em que se caminha sobre o tapete desenrolado para o interior de uma catedral onde se realizam ritos que me são estranhos. Eu não me caso nem morro. E a distância entre a multidão, entre mim e os outros, alarga-se. 
I am floating again. All the facts and all the words, all images, all presages are sweeping over me, mocking each other. The dream! The dream! The dream rings through me like a giant copper bell when I wish to betray it. It brushes by me with bat wings when I open human eyes and seek to live dreamlessly. When human pain has struck me fiercely, when anger has corroded me, I rise, I always rise after the crucifixion, and I am in terror of my ascensions. THE FISSURE IN REALITY. The divine departure. I fall. I fall into darkness after the collision with pain, and after pain the divine departure.

Oh, the weight, the tremendous weight of my head pulled up by the clouds and swinging in space, the body like a wisp of straw, the clouds dragging my hair like a scarf caught in a chariot wheel, the body dangling, colliding with the lantern stars, the clouds dragging me over the world.

I cannot stop, or descend.

I hear the unfurling of water, of skies and curtains. I hear the shiver of leaves, the breathing of the air, the wailing of the unborn, the pressure of the wind.

I hear the movements of the stars and planets, the slight rust creak when they shift their position. The silken passage of radiations, the breath of circles turning.

I hear the passing of mysteries and the breathing of monsters. Overtones only, or undertones. Collision with reality blurs my vision and submerges me into the dream. I feel the distance like a wound. It unrolls itself before me like a rug before the steps of a cathedral for a wedding or a burial. It is unrolled like a crimson bride between the others and me, but I cannot walk on it without a feeling of uneasiness, as one has at ceremonies. The ceremony of walking along the unrolled carpet into the cathedral where the functions unravel to which I am a stranger. I neither marry or die. And the distance between the crowd, between the others and me, grows wider. 
Distância. Nunca andei por sobre o tapete em cerimônias. Rumo à plenitude da vida da multidão, à autêntica música e ao odor dos homens. Nunca fui a casamentos nem funerais. Para mim, tudo acontecia ou no campanário onde ficava sozinha ao som ensurdecedor dos sinos a chamar com suas vozes de ferro, ou no porão onde, junto aos ratos, roía as velas e o incenso.

Não consigo ter certeza de qualquer acontecimento ou lugar a não ser de minha solidão. Diga-me o que as estrelas contam a meu respeito. Saturno tem olhos de cebola que choram o tempo todo? Mercúrio tem penas de galinha nos calcanhares, e Marte usa máscara de gás? Gêmeos, os gêmeos evoluídos, eles evoluem o tempo todo, girando em um espeto, Gemini à la broche?

Há uma fratura em minha visão que a loucura sempre penetra. Debruça-te sobre mim, à beira da cama de minha loucura e deixa-me em pé sem muletas.

Sou uma mulher louca para quem as casas piscam e abrem seus ventres. De todos os lados os sentidos das coisas me fitam feito um enorme fantasma à espreita. $\mathrm{O}$ sentido emerge de becos úmidos e de faces sombrias e debruça-se nas janelas de casas estranhas. Reconstruo sem parar o modelo de algo que se perdeu para sempre e que não consigo esquecer. Agarro nas esquinas os cheiros do passado e tenho consciência dos homens que irão nascer amanhã. Por detrás das janelas ou há inimigos ou adoradores. Nunca neutralidade ou passividade. Sempre intenção e premeditação. Até as pedras têm para mim expressões druídicas.

Caminho à minha frente, na eterna expectativa de milagres.

Enredada em minhas mentiras, desejo absolvição. Não posso dizer a verdade porque senti cabeças de homens em meu ventre. A verdade seria letal e prefiro contos de fada.

Estou envolta em um emaranhado de mentiras que não penetram minha alma. Como se as mentiras que conto fossem vestes de fantasia. A concha do mistério pode se quebrar e crescer novamente da noite pro dia. Mas, no momento em que adentro a caverna de minhas mentiras, caio na escuridão. Vejo um rosto que me encara como o olhar de um homem vesgo. 
Distance. I never walked over the carpet into the ceremonies. Into the fullness of the crowd life, into the authentic music and the odor of men. I never attended the wedding or burial. Everything for me took place either in the belfry where I was alone with the deafening sound of bells calling in iron voices, or in the cellar where I nibbled at the candles and the incense stored away with the mice.

I cannot be certain of any event or place, only of my solitude. Tell me what the stars are saying about me. Does Saturn have eyes made of onions which weep all the time? Has Mercury chicken feathers on his heels, and does Mars wear a gas mask? Gemini, the evolved twins, do they evolve all the time, turning on a spit, Gemini à la broche?

There is a fissure in my vision and madness will always rush through. Lean over me, at the bedside of my madness, and let me stand without crutches.

I am an insane woman for whom houses wink and open their bellies. Significance stares at me from everywhere, like a gigantic underlying ghostliness. Significance emerges out of dank alleys and sombre faces, leans out of the windows of strange houses. I am constantly reconstructing a pattern of something forever lost and which I cannot forget. I catch the odors of the past on street corners and I am aware of the men who will be born tomorrow. Behind windows there are either enemies or worshippers. Never neutrality or passivity. Always intention and premeditation. Even stones have for me druidical expressions.

I walk ahead of myself in perpetual expectancy of miracles.

I am enmeshed in my lies, and I want absolution. I cannot tell the truth because I have felt the heads of men in my womb. The truth would be death-dealing and I prefer fairytales. I am wrapped in lies which do not penetrate my soul. As if the lies I tell were like costumes. The shell of mystery can break and grow again over night. But the moment I step into the cavern of my lies I drop into darkness. I see a face which stares at me like the glance of a cross-eyed man. 
Lembro-me do frio e da amônia congelando em Júpiter de cujos cristais saiam anjos. Faixas de amônia e metano em torno de Urano. Lembro-me dos furacões de metano inflamável em Saturno. Lembro-me da vegetação em Marte semelhante ao capim do Peru e da Patagônia, de um vermelho ocre, uma vegetação de minério enferrujado, musgos e líquens. Ferro de argila vermelha e de arenito vermelho. Neste lugar, as luzes tinham som e a luz solar era uma orquestra. 
I remember the cold on Jupiter freezing ammonia and out of ammonia crystals came the angels. Bands of ammonia and methane encircling Uranus. I remember the tornadoes of inflammable methane on Saturn. I remember on Mars a vegetation like the tussock grasses of Peru and Patagonia, an ochrous red, a rusty ore vegetation, mosses and lichens. Iron bearing red clays and red sandstone. Light there had a sound and sunlight was an orchestra. 
Olhos dilatados, perfil de raça nobre, boca obstinada. Jeanne, toda em pele, com cílios de pele, andar altivo, nariz ao vento, olhos nas estrelas, a caminhar de forma imperiosa e a arrastar sua perna defeituosa. Seus olhos acima do nível humano, a perna a mancar na esteira de sua altivez, inerte, como a bola acorrentada de um prisioneiro.

Prisioneira da terra, contra a sua vontade de morrer.

A perna a se arrastar para que Jeanne permaneça na terra, uma perna pesada e morta que ela carregava como se fosse a bola e a corrente de um prisioneiro.

Seus dedos pálidos, manchados de nervos torturavam o violão, sua timidez atormentava e retorcia as cordas enquanto cantava em voz baixa; e por trás da música, sua sede, sua fome e seus temores. Ao afinar o violão, girou a tarraxa de forma tão violenta que a corda arrebentou e seus olhos ficaram aterrorizados como se seu universo tivesse sido arrebentado.

Cantava e ria: amo meu irmão.

Amo meu irmão. Quero cruzadas e martírio. Acho o mundo pequeno demais.

Lágrimas salgadas de derrota cristalizaram-se nos cantos de seus olhos inquietos.

Mas eu nunca choro.

Pegou um espelho e se olhou enternecidamente.

Narciso se mirando em espelhos Lanvin. Os Quatro Cavaleiros do Apocalipse atravessando o Bois. A tragédia que se move sobre pneus de aço.

O mundo é pequeno demais. Estou cansada de tocar violão, de fazer tricô, de passear e de ter filhos. Os homens são limitados e as paixões duram pouco. Fico enfurecida diante de escadas, portas, paredes, enfurecida com a vida cotidiana que interfere na continuidade do êxtase.

No entanto, há o martírio da tensão, da febre, de se viver sem interrupções como o firmamento em pleno movimento e em pleno esplendor.

Ninguém nunca viu as estrelas ficarem cansadas ou sem brilho. Jamais adormecem. 
Dilated eyes, noble-raced profile, wilful mouth. Jeanne, all in fur, with fur eyelashes, walking with head carried high, nose to the wind, eyes on the stars, walking imperiously, dragging her crippled leg. Her eyes higher than the human level, her leg limping behind the tall body, inert, like the chained ball of a prisoner.

Prisoner on earth, against her will to die.

Her leg dragging so that she might remain on earth, a heavy dead leg which she carried like the ball and chain of a prisoner.

Her pale, nerve-stained fingers tortured the guitar, tormenting and twisting the strings with her timidity as her low voice sang; and behind her song, her thirst, her hunger and her fears. As she turned the keys of her guitar, fiercely tuning it, the string snapped and her eyes were terror-stricken as by the snapping of her universe.

She sang and she laughed: I love my brother.

I love my brother. I want crusades and martyrdom. I find the world too small.

Salted tears of defeat crystallized in the corners of her restless eyes.

\section{But I never weep.}

She picked up a mirror and looked at herself with love.

Narcisse gazing at himself in Lanvin mirrors. The Four Horsemen of the Apocalypse riding through the Bois. Tragedy rolling on cord tires.

The world is too small. I get tired of playing the guitar, of knitting, and walking, and bearing children. Men are small, and passions are short-lived. I get furious at stairways, furious at doors, at walls, furious at everyday life which interferes with the continuity of ecstasy.

But there is martyrdom of tenseness, of fever, of living continuously like the firmament in full movement and in full effulgence.

You never saw the stars grow weary or dim. They never sleep. 
Sentou-se olhando num espelho de mão tentando tirar um cílio que caíra no olho.

Eu me casei com um homem, disse Jeanne, que nunca tinha visto olhos pintados chorarem, e no dia do meu casamento eu chorei. Ele me olhou e viu uma mulher derramar enormes lágrimas pretas, lágrimas pretas de verdade. Ficou muito assustado ao me ver derramando lágrimas pretas na noite do casamento. Quando ouvi os sinos tocando, achei que tocavam alto demais. Ensurdeciam-me. Senti que iria começar a chorar sangue, meus ouvidos doíam tanto. Tossi porque o barulho era imenso e aterrorizante, como da vez que fiquei ao lado dos sinos de Chartres. Ele dizia que, de modo algum, os sinos estavam tocando alto, mas eu os escutava tão próximos que sequer conseguia ouvir sua voz, e o barulho parecia marteladas em minha carne, e achei que meus ouvidos fossem explodir. Cada célula do meu corpo começou a explodir, uma a uma, dentro do barulho imenso do qual não podia escapar. Tentei fugir dos sinos. E gritei: parem de tocar os sinos! Mas não conseguia fugir porque o som estava à minha volta e dentro de mim, meu coração batendo violentamente como se feito de ferro, minhas artérias batendo como se fossem címbalos, feito minha cabeça batendo contra o granito e o martelo acertando as veias em minhas têmporas. Explosões de sons sem trégua faziam minhas células estourarem e o eco de coisas rachando e quebrando dentro de mim se desdobrava em outros ecos, atingindo-me sem cessar até que meus nervos se retorciam e enrolavam e então estalavam e rompiam ao som do sino, até que minha carne se contraiu e encolheu de dor e sangue escorreu de meus ouvidos e eu não pude mais suportar... Não pude suportar ir ao meu próprio casamento, não pude suportar casar com um homem porque, porque, porque...

\section{AMO MEU IRMÃO!}

Balançou as pesadas pulseiras indianas; acariciou as jarras azuis do oriente e se deitou novamente.

Eu sou a mulher mais cansada do mundo. Estou cansada quando me levanto. A vida requer um esforço que não sou capaz. Por favor, me dê aquele livro pesado. Preciso pôr algo pesado sobre minha cabeça. Sempre coloco meus pés embaixo do travesseiro para que eu consiga permanecer na terra. Caso contrário, sinto que estou indo embora, indo embora em altíssima velocidade por causa da minha leveza. Sei que estou morta. 
She sat looking at herself in a hand mirror and searching for an eyelash which had fallen into her eye.

I married a man, Jeanne said, who had never seen painted eyes weep, and on the day of my wedding I wept. He looked at me and he saw a woman shedding enormous black tears. It frightened him to see me shedding black tears on my wedding night. When I heard the bells ringing I thought they rang far too loud. They deafened me. I felt I would begin to weep blood, my ears hurt me so much. I coughed because the din was immense and terrifying, like the time I stood next to the bells of Chartres. He said the bells were not loud at all, but I heard them so close to me that I could not hear his voice, and the noise seemed like hammering against my flesh, and I thought my ears would burst. Every cell in my body began to burst, one by one, inside of the immense din from which I could not escape. I tried to run away from the bells. I shouted: stop the bells from ringing! But I could not run away from them because the sound was all around me and inside me, like my heart pounding in huge iron beats, like my arteries clamping like cymbals, like my head knocked against granite and a hammer striking the vein on my temple. Explosions of sounds without respite which made my cells burst, and the echoes of the cracking and breaking in me rolled into echoes, struck me again and again until my nerves were twisting and curling inside me, and then snapped and tore at the gong, until my flesh contracted and shrivelled with pain, and the blood spilled out of my ears and I could not bear any more...Could not bear to attend my own wedding, could not bear to be married to man, because, because, because...

\section{LOVE MY BROTHER!}

She shook her heavy Indian bracelets; she caressed her Orient blue bottles, and then she lay down again.

I am the most tired woman in the world. I am tired when I get up. Life requires an effort which I cannot make. Please give me that heavy book. I need to put something heavy like that on top of my head. I have to place my feet under the pillows always, so as to be able to stay on earth. Otherwise I feel myself going away, going away at a tremendous speed, on account of my lightness. I know that I am dead. 
Tão logo digo uma frase minha sinceridade morre, torna-se uma mentira cuja frieza me estremece. Não precisa dizer nada porque sei que me compreendes e tenho medo da tua compreensão. Tenho pavor de encontrar alguém parecido comigo e ao mesmo tempo desejo muito que isso aconteça. Sinto-me completamente só, mas tenho medo que meu isolamento possa ser quebrado e eu não seja mais a senhora do meu universo. Tua compreensão me causa grande temor e é por meio dela que penetras em meu mundo; e, então, deixo- me revelar e sou obrigada a compartilhar meu reino contigo.

É o medo da loucura, Jeanne, só o medo da loucura é que irá nos expulsar da esfera de nossa solidão, para fora do sagrado da nossa solidão. $\mathrm{O}$ medo da loucura queimará as paredes da nossa casa secreta e nos lançará ao mundo, à procura de calor humano. Aqueles mundos que nós mesmas criamos e alimentamos estão repletos de monstros e fantasmas.

Conhecer apenas o medo, é verdade, tanto medo que me sufoca, e permaneço ofegante e sem fôlego, como alguém a quem falta o ar; outras vezes, não consigo ouvir, e fico subitamente surda para o mundo. Bato meus pés e não ouço nada. Grito e não ouço meu grito. Também, às vezes, quando me deito, o medo me invade novamente e um terror imenso do silêncio e do que dele virá bate nas paredes das minhas têmporas e vai se intensificando e me sufoca. Bato na parede e no chão para dispersar o silêncio. Bato, canto e assobio sem parar até que o medo vá embora.

Quando sento diante do espelho rio de mim mesma. Penteio os cabelos. Aqui, um par de olhos, duas tranças compridas, dois pés. Olho para eles como se fossem dados dentro de uma caixa, e penso se devo sacudi-los. Se saíssem da caixa continuariam sendo EU? Não sei dizer como todas essas peças separadas podem ser EU. Eu não existo. Não sou um corpo. Quando aperto a mão de alguém sinto esta pessoa tão distante que ela está no outro quarto e a minha mão, também, está no outro quarto. Quando assôo o nariz, receio que ele fique no lenço.

Voz de um sabiá. A sombra da morte perseguindo cada palavra, a murchá-las, antes que Jeanne tenha terminado de pronunciá-las.

Quando meu irmão sentou-se ao sol, beijei a sombra de seu rosto projetada na parte de trás da cadeira. Beijei sua sombra e esse beijo não o tocou, o beijo ficou perdido no ar e se dissolveu na sombra. O nosso amor um pelo outro é um longo beijo de sombras, sem esperança de realidade. 
As soon as I utter a phrase my sincerity dies, becomes a lie whose coldness chills me. Don't say anything, because I see that you understand me, and I am afraid of your understanding. I have such a fear of finding another like myself, and such a desire to find one! I am so utterly lonely, but I also have such a fear that my isolation be broken through, and I no longer be the head and ruler of my universe. I am in great terror of your understanding by which you penetrate into my world; and then I stand revealed and I have to share my kingdom with you.

But Jeanne, fear of madness, only the fear of madness will drive us out of the precincts of our solitude. The fear of madness will burn down the walls of our secret house and send us out into the world seeking warm contact. Worlds self-made and selfnourished are so full of ghosts and monsters.

Knowing only fear, it is true, such a fear that it chokes me, that I stand gasping and breathless, like a person deprived of air; or at other times, I cannot hear, I suddenly become deaf to the world. I stamp my feet and hear nothing. I shout and hear nothing of my shout. And then at times, when I lie in bed, fear clutches me again, a great terror of silence and of what will come out of this silence towards me and knock on the walls of my temples, a great mounting, choking fear. I knock on the wall, on the floor, to drive the silence away. I knock and I sing I whistle persistently until I drive the fear away.

When I sit before my mirror I laugh at myself. I am brushing my hair. Here are a pair of eyes, two long braids, two feet. I look at them like dice in a box, wondering if I should shake them, would they still come out and be ME. I cannot tell how all these separate pieces can be ME. I do not exist. I am not a body. When I shake hands I feel that the person is so far away that he is in the other room, and that my hand is in the other room. When I blow my nose I have a fear that it might remain on the handkerchief.

Voice like a mistle thrush. The shadow of death running after each word so that they wither before she has finished uttering them.

When my brother sat in the sun and his face was shadowed on the back of the chair I kissed his shadow. I kissed his shadow and his kiss did not touch him, this kiss was lost in the air and melted with the shadow. Our love of each other is like one long shadow kissing, without hope of reality. 
Jeanne me levou à casa do incesto. Era a única casa que não estava incluída nas doze casas do Zodíaco e não se podia chegar a ela nem pela rota da via láctea, nem a bordo do navio de vidro cujo casco transparente permitia acompanhar os contornos dos continentes perdidos, nem seguindo as setas que apontam a direção do vento, nem seguindo a voz dos ecos das montanhas.

Os quartos eram interligados por degraus - nenhum quarto ficava no mesmo nível do outro - e todos os degraus estavam profundamente gastos. Havia janelas entre os quartos, pequenas janelas de vidro espelhado de modo que era possível conversar no escuro sem ver os rostos uns dos outros. Os quartos eram invadidos pela ondulação rítmica do mar que vinha das inúmeras conchas. As janelas davam para um mar estático onde peixes imóveis haviam sido grudados em um fundo pintado. Tudo na casa do incesto fora feito para permanecer imóvel, já que todos tinham medo do movimento e do calor, um medo enorme de que todo o amor e toda a vida se esvaíssem e perdessem.

Tudo havia sido feito para permanecer imóvel, e tudo estava apodrecendo. O sol fora pregado no teto do céu e a lua cravada em seu nicho oriental.

$\mathrm{Na}$ casa do incesto havia um quarto que não podia ser encontrado, um quarto sem janela, fortaleza de seus amores, um quarto sem janela onde a mente e o sangue fundiam-se numa união sem orgasmo e sem raízes, como na união dos peixes. A promiscuidade de olhares, de frases, feito faíscas casando-se no espaço. O choque entre suas semelhanças, exalando odor de tamargueira e areia, de conchas apodrecidas e algas agonizantes, o amor feito tinta de lulas, banquete de venenos.

Cambaleando de um quarto a outro, cheguei ao quarto das pinturas, e lá estava Lot sentado com a mão sobre o seio da filha enquanto, ao fundo, a cidade em chamas se partia e afundava no mar. Ali, onde estava sentado junto à filha, o tapete oriental era resistente e vermelho, mas o tremor que sacudia seus corpos, também, se revelava nas rochas que se partiam ao redor, na terra que se abria sob seus pés, nas árvores incendiadas feito tochas, no céu esfumaçado e em brasa, tudo se rompendo ao prazer e terror desse amor. O prazer da mão do pai sobre o seio da filha, o prazer do medo que a dilacera. A roupa bem justa para que os seios se avolumem e cresçam sob os dedos do pai, enquanto a cidade é cindida por um raio, e cospe, sob dentes de fogo, enormes blocos de ruínas, que se afundam ao horror da obscenidade, atirados ao mar ao som sibilante daquilo que está eternamente amaldiçoado. 
She led me into the house of incest. It was the only house which was not included in the twelve houses of the zodiac. It could neither be reached by the route of the milky way, nor by the glass ship through whose transparent bottom one could follow the outline of the lost continents, nor by following the arrows pointing the direction of the wind, nor by following the voice of the mountain echoes.

The rooms were chained together by steps - no room was on a level with another - and all the steps were deeply worn. There were windows between the rooms, little spying-eyed windows, so that one might talk in the dark from room to room, without seeing the other's face. The rooms were filled with the rhythmic heaving of the sea coming from many sea-shells. The windows gave out on a static sea, where immobile fishes had been glued to painted backgrounds. Everything had been made to stand still in the house of incest, because they all had such a fear of movement and warmth, such a fear that all love and all life should flow out of reach and be lost!

Everything had been made to stand still, and everything was rotting away. The sun had been nailed in the roof of the sky and the moon beaten deep into its Oriental niche.

In the house of incest there was a room which could not be found, a room without window, the fortress of their love, a room without window where the mind and blood coalesced in a union without orgasm and rootless like those of fishes. The promiscuity of glances, of phrases, like sparks marrying in space. The collision between their resemblances, shedding the odor of tamarisk and sand, of rotted shells and dying sea-weeds, their love like the ink of squids, a banquet of poisons.

Stumbling from room to room I came into the room of paintings, and there sat Lot with his hand upon his daughter's breast while the city burned behind them, cracking open and falling into the sea. There where he sat with his daughter the Oriental rug was red and stiff, but the turmoil which shook them showed through the rocks splitting around them, through the earth yawning beneath their feet, through the trees flaming up like torches, through the sky smoking and smouldering red, all cracking with the joy and terror of their love. Joy of the father's hand upon the daughter's breast, the joy of the fear racking through her. Her costume tightly pressed around her so that her breasts heave and swell under his fingers, while the city is rent by lightning and spits under the teeth of fire, great blocks of a gaping ripped city sinking with the horror of obscenity, and falling into the sea with the hiss of the eternally damned. 
Nenhum grito de horror vindo de Lot ou sua filha, apenas o grito da cidade em chamas, de um desejo insaciável de pai e filha, de irmão e irmã, de mãe e filho.

Olhei o relógio para encontrar a verdade. As horas passavam como peças de xadrez feitas de marfim, golpeando notas de piano, e os minutos corriam sobre fios, cavalgando como soldadinhos de lata. Horas que se assemelham à mulheres altas de ébano com gongos entre as pernas, soando continuamente, para que eu não consiga contá-las. Ouvi o balanço das batidas de meu coração; ouvi os passos de meus sonhos; e a batida do tempo se perdeu entre eles feito a face da verdade.

Deparei-me com uma floresta de árvores decapitadas, mulheres esculpidas no bambu, carnes flageladas tal qual de escravos em triste servidão, rostos cortados ao meio pela faca do escultor, mostrando duas faces para sempre separadas, eternamente duas faces e era eu que tinha de mover-me para contemplar toda a mulher. Figuras assimétricas, truncadas, onze lados, onze ângulos, madeiras venosas e vulneráveis, fragmentos de corpos, corpos sem braços e sem cabeças. O torso de uma tuberosa, o joelho de Aquiles, tubérculos e excrescências, o pé de uma múmia em madeira apodrecida, madeira dócil e venosa esculpida em contorções humanas. A floresta chora e curva-se como os ombros de um homem, figuras mortas dentro de árvores vivas. Agora, uma floresta animada com expressões intelectuais, contorções intelectuais. Árvores que se tornam homem e mulher, de faces duplas, nostálgicas do estremecer das folhas. Árvores que se deitam, madeiras reluzentes, e a floresta tremendo em rebelião tão amarga que ouço seu pranto em sua profunda consciência de floresta. O lamento da perda de suas folhas e o fracasso da transmutação.

Adiante, uma floresta de gesso branco, ovos de gesso branco. Enormes ovos brancos em discos prateados, uma elegia ao nascimento, cada ovo uma promessa, nascença de homem, mulher ou animal em formação ainda não precisa. Útero e semente e ovo, culto ao úmido princípio e não a seu desabrochar. Ovos tão brancos, tão silenciosos, deram origem à esperança sem que fosse necessário quebrá-los, mas a árvore derrubada que ali jazia gerou um galho vivo e verde que zomba do escultor. 
No cry of horror from Lot and his daughter but from the city in flames, from an unquenchable desire of father and daughter, of brother and sister, mother and son.

I looked upon a clock to find the truth. The hours were like ivory chess figures, striking piano notes, and the minutes raced on wires mounted like tin soldiers. Hours like tall ebony women with gongs between their legs, tolling continuously so that I could not count them. I heard the rolling of my heart-beats; I heard the footsteps of my dreams, and the beat of time was lost among them like the face of truth.

I came upon a forest of decapitated trees, women carved out of bamboo, flesh slatted like that of slaves in joyless slavery, faces cut in two by the sculptor's knife, showing two sides forever separate, eternally two-faced, and it was I who had to shift about to behold the entire woman. Truncated unsymmetrical figures, eleven sides, eleven angles, in veined and vulnerable woods, fragments of bodies, bodies armless and headless. The torso of a tube-rose, the knee of mummy in rotted wood, the veined docile wood carved into human contortions. The forest must weep and bend like the shoulders of men, dead figures inside of live trees. A forest animated now with intellectual faces, intellectual contortions. Trees become man and woman, two-faced, nostalgic for the shivering of leaves. Trees reclining, woods shining, and the forest trembling with rebellion so bitter I heard its wailing within its deep forest consciousness. Wailing the loss of its leaves and the failure of transmutation.

Further a forest of white plaster, white plaster eggs. Large white eggs on silver disks, an elegy to birth, each egg a promise, each half-shaped nascence of man or woman or animal not yet precise. Womb and seed and egg, the moist beginning being worshipped rather than its flowering. The eggs so white, so still, gave birth to hope without breaking, but the cut-down tree lying there produced a green live branch that laughed at the sculptor. 
Jeanne abriu todas as portas e procurou em todos os quartos. Em cada quarto, o hóspede, assustado, piscava ao ser pego de surpresa. Ela lhes pedia: "Por favor, pendurem qualquer coisa na janela. Pode ser um xale, um lenço colorido ou um tapete. Vou até o jardim. Quero ver se existe uma janela a mais. Quem sabe, assim, eu encontro o quarto onde meu irmão se esconde. Não consigo achar meu irmão. Imploro a cada um de vocês que me ajudem." Retirou a toalha das mesas, retirou uma cortina vermelha, pegou uma colcha coral, um painel chinês e, ela mesma, os pendurou na janela.

Depois, correu até o jardim de árvores mortas, pelas trilhas de lava, de quartzo, e todos os minerais derretiam enquanto passava, a moscovita como uma noiva, a pirita, a sílica aquosa, o cinábrio, o azurite feito um fragmento do benéfico Júpiter, a malaquita, todos triturados, prensados, joias derretidas, planetas derretidos, alquemizados pelo ar e o sol e o tempo e o espaço, misturados na fixidez mineral, a fixidez do medo da morte e do medo da vida.

Sêmen ressecado em silêncio pétreo e mineral. As palavras que não gritamos, as lágrimas que não derramamos, a maldição que engolimos, a frase que encurtamos, o amor que assassinamos, tudo isso transformado em minério de ferro magnético, em turmalina, em ágata, sangue congelado em cinábrio, sangue calcinado, sangue transformado em galena, oxidado, aluminizado, sulfatado, calcinado, o brilho mineral de meteoros mortos e sóis exaustos na floresta de árvores mortas e desejos mortos.

Em pé sobre uma colina de ortoclásio, com manchas de topázio e argentita nas mãos, Jeanne observou a fachada da casa do incesto, a fachada de minério enferrujada da casa do incesto, e havia uma janela fechada e enferrujada, uma janela sem luz feito um olho cego, sufocada pelos braços longos e peludos de uma antiga hera.

O desejo de não gritar a fez estremecer, um esforço tamanho que ela permaneceu imóvel, sangue imperceptível na palidez dourada de seu rosto.

Debatia-se com a chegada da morte: eu não amo ninguém, não amo ninguém, nem mesmo meu irmão. Não amo coisa alguma, a não ser essa ausência de dor, essa fria e neutra ausência de dor.

Por muitos anos, parada, entre o momento da perda de seu irmão e o momento em que viu a fachada da casa do incesto, movendo-se em círculos infinitos pelas esquinas do sonho, sem jamais chegar ao fim de sua jornada, absorveu todo o espanto pela idade de rocha de seu sofrimento, ao morrer. 
Jeanne opened all the doors and searched through all the rooms. In each room the startled guest blinked with surprise. She asked them: "Please hang up something out of your windows. Hang up a shawl, or a colored handkerchief, or a rug. I am going out into the garden. I want to see how many windows can be accounted for. I may thus find the room where my brother is hiding from me. I have lost my brother. I beg you, help me, everyone of you." She pulled shawls off the tables, she took a red curtain down, a coral bedspread, a Chinese panel, and hung them out of the windows herself.

Then she rushed out into the garden of dead trees, over the lava paths, over the micha schist, and all the minerals on her path burned, the muscovite like a bride, the pyrite, the hydrous silica, the cinnabar, the azurite like a fragment of benefic Jupiter, the malachite, all crushed together, pressed together, melted jewels, melted planets, alchemized by air and sun and time and space, mixed into mineral fixity, the fixity of the fear of death and the fear of life.

Semen dried into the silence of rock and mineral. The words we did not shout, the tears unshed, the curse we swallowed, the phrase we shortened, the love we killed, turned into magnetic iron ore, into tourmaline, into pyrate agate, blood congealed into cinnabar, blood calcinated, leadened into galena, oxidized, aluminized, sulphated, calcinated, the mineral glow of dead meteors and exhausted suns in the forest of dead trees and dead desires.

Standing on a hill of orthoclase, with topaz and argentite stains on her hands, she looked up at the façade of the house of incest, the rusty ore façade of the house of incest, and there was one window with the blind shut tight and rusty, one window without light like a dead eye, choked by the hairy long arm of old ivy.

She trembled with the desire not to shriek, an effort so immense that she stood still, her blood unseen for the golden pallor of her face.

She struggled with her death coming: I do not love anyone; I love no one, not even my brother. I love nothing but this absence of pain, this cold neutral absence of pain.

Standing still for many years, between the moment she had lost her brother and the moment she had looked at the façade of the house of incest, moving in endless circles round the corners of the dreams, never reaching the end of her voyage, she apprehended all wonder through the rock-agedness of her pain, by dying. 
E encontrou seu irmão adormecido entre os quadros.

Jeanne, adormeci entre os quadros, e aqui poderia ficar por muitos dias venerando teu retrato. Apaixonei-me pelo teu retrato porque ele nunca irá mudar. Tenho muito medo de vê-la envelhecer, Jeanne; Apaixonei-me por um tu imutável, que nunca será tirado de mim. Queria que tu morresses para que ninguém pudesse tirá-la de mim e eu amaria a pintura de sua aparência eterna.

Somente uma parte deles se cumprimentou - suas semelhanças.

Boa noite, irmão!

Boa noite, Jeanne!

Junto a ela caminhavam sombras alongadas, estigmatizadas pelo medo. Carregavam um pacto feito joia no peito; exibiam-na com orgulho, como um brasão. 
And she found her brother asleep among the paintings.

Jeanne, I fell asleep among the paintings, where I could sit for many days worshipping your portrait. I fell in love with your portrait, Jeanne, because it will never change. I have such a fear of seeing you grow old, Jeanne, I fell in love with an unchanging you that will never be taken away from me. I was wishing you would die, so that no one could take you away from me, and I would love the painting of you as you would look eternally.

They bowed to one part of themselves only - their likeness.

Good night, my brother!

Good night, Jeanne!

With her walked distended shadows, stigmatized by fear. They carried their compact like a jewel on their breast; they wore it proudly like their coat of arms. 
Adentrei meu livro em busca de paz.

Era noite e me movi desatenta no interior do sonho. Ao virar bruscamente a esquina me feri em minha loucura. Ver além do que é suportável, a tragédia anunciada no estremecer de uma pálpebra, um crime arquitetado no quarto ao lado, homens e mulheres que se amaram antes de mim na mesma cama de hotel.

Carrego esponjas brancas de conhecimento nos fios de meus nervos.

À medida que adentro o livro, sou cortada por cacos de vidro e garrafas quebradas onde ainda persiste o cheiro de esperma e perfume.

Mais páginas são acrescentadas ao livro, páginas que lembram o vaivém de um prisioneiro no espaço a ele destinado. E a mim, o que foi predestinado dizer? Apenas a verdade disfarçada num conto de fadas, e é por trás deste conto de fadas que todas as verdades espiam como se estivessem detrás das grades das janelas de uma mesquita. Verdades que usam véus. Assim que piso na caverna das minhas mentiras, caio nas trevas, e vejo uma máscara que me fita tal qual o olhar de um homem vesgo; contudo, estou envolta em mentiras que não penetram minha alma, como se as mentiras que digo fossem vestes de fantasia.

\section{MENTIRAS CRIAM SOLIDÃO}

Saí de meu livro e entrei no quarto do paralítico.

Ele estava sentado, rodeado por inúmeros objetos sob uma redoma de vidro, como em um museu. Havia recolhido uma caixa de tintas que nunca fora usada, milhares de livros com páginas não cortadas, cobertos por poeira. Sua capa espanhola pendurada nos ombros de um manequim, no chão o violão de cordas arrebentadas qual uma cabeleira em desalinho. Sentou-se diante de um caderno de folhas brancas e disse: engulo minhas próprias palavras. Mastigo e mastigo tudo até que se deteriore. Mastiguei cada pensamento, cada impulso até que se desintegrasse por completo. Desejo capturar todos os meus pensamentos de uma vez, mas eles fogem em todas as direções. Se conseguisse, poderia capturar a mais ágil de todas as mentes, como um cardume de minúsculos peixes. Revelaria inocência e duplicidade, generosidade e cálculo, covardia, medo e coragem. Desejo expressar toda a verdade, mas não posso dizer toda a verdade porque teria de escrever quatro páginas de uma só vez, como se fossem quatro colunas simultâneas, quatro páginas em uma única página e é por isso que não escrevo nada. Teria de escrever em reverso, remontar meus passos constantemente para capturar ecos e sobretons. 
I walked into my own book, seeking peace.

It was night, and I made a careless movement inside the dream; I turned too brusquely the corner and bruised myself against my madness. It was this seeing too much, this seeing of a tragedy in the quiver of an eyelid, constructing a crime in the next room, the men and women who had loved before me on the same hotel bed.

I carry white sponges of knowledge on strings of nerves.

As I move within my book I am cut by pointed glass and broken bottles in which there is still the odor of sperm and perfume.

More pages added to the book but pages like a prisoner's walking back and forth over the space allotted him. What is it allotted me to say? Only the truth disguised in a fairytale, and this is the fairytale behind which all the truths are staring as behind grilled mosque windows. With veils. The moment I step into the cavern of my lies I drop into darkness, and see a mask which stares at me like the glance of a cross-eyed man; yet I am wrapped in lies which do not penetrate my soul, as if the lies I tell were like costumes.

\section{LIES CREATE SOLITUDE}

I walked out of my book into the paralytic's room.

He sat there among many objects under glass as in a museum. He had collected a box of paint which he never painted with, a thousand books with pages uncut, and they were covered with dust. His Spanish cape hung on the shoulders of a mannequin, his guitar lay with strings snapped like long disordered hair. He sat before a note book of blank pages, saying: I swallow my own words. I chew and chew everything until it deteriorates. Every thought or impulse I have is chewed into nothingness. I want to capture all my thoughts at once, but they run in all directions. If I could do this I would be capturing the nimblest of minds, like a shoal of minnows. I would reveal innocence and duplicity, generosity and calculation, fear and cowardice and courage. I want to tell the whole truth, but I cannot tell the whole truth because I would have to write four pages at once, like four columns simultaneously, four pages to the present one, and so I do not write at all. I would have to write backwards, retrace my steps constantly to catch the echoes and the overtones. 
A pele do paralítico era transparente como a de um bebê recém-nascido e seus olhos verdes como musgo. Cumprimentou Sabina, Jeanne e a mim: eis o Cristo moderno, crucificado pelos seus próprios nervos, por todos os nossos pecados neuróticos!

O Cristo moderno enxugou o suor que escorria no rosto como se ali, sentado, sofresse a agonia de uma tortura secreta. Traços esculpidos pela dor. Olhos bem abertos como se dilatados pelas cenas de horror. Pálpebras pesadas que sustentam o peso do cansaço do mundo. Sentado numa cadeira como se houvesse fantasmas ao seu redor. Um sorriso feito insulto. Lábios murchos e cobertos pela espuma negra do ópio. O corpo tenso como arame.

Somos irmãos na escrita, eu disse. A velocidade de nossas vertigens é a mesma. Chegamos ao mesmo lugar na mesma hora, coisa que não ocorre na mente de outras pessoas. A linguagem de nervos que usamos nos torna irmãos na escrita.

O Cristo moderno disse: nasci sem pele. Uma vez sonhei que estava nu em um jardim e que era descascado com esmero e destreza, feito um fruto. Nenhum milímetro de pele sequer restou em meu corpo. Minha pele delicadamente arrancada, toda ela e, então, me disseram que andasse, vivesse, corresse. A princípio, andava devagar e o jardim era bem macio, e sentia a intensa maciez do jardim, não na superfície de meu corpo, mas por todo meu ser. $\mathrm{O}$ ar suave e quente e os perfumes penetravam em mim como agulhas em cada poro aberto sangrando. Todos os poros abertos e respirando suavidade, calor, aromas. O corpo inteiro invadido, penetrado, reagindo, cada minúscula célula e cada poro ativos e respirando e tremendo e sentindo prazer. Gritei de dor. Fugi. Enquanto corria, o vento me açoitava e as vozes das pessoas eram como chicotes. Ser tocado! Sabes o que é ser tocado por um ser humano!

Enxugou o rosto com um lenço.

O paralítico permanecia quieto num canto do quarto.

Tu és afortunada, disse ele, tu és afortunada por ser capaz de sentir intensamente; Quisera eu sentir com tanta intensidade. Pelo menos estás viva para a dor, enquanto eu... 
His skin was transparent like that of a newborn child, and his eyes green like moss. He bowed to Sabina, to Jeanne, and to me: meet the modern Christ, who is crucified by his own nerves, for all our neurotic sins!

The modern Christ was wiping the perspiration which dripped over his face, as if he were sitting there in the agony of a secret torture. Paincarved features. Eyes too open, as if dilated by scenes of horror. Heavy-lidded, with a world-heavy fatigue. Sitting on his chair as if there were ghosts standing beside him. A smile like an insult. Lips edged and withered by the black scum of drugs. A body taut like wire.

In our writings we are brothers, I said. The speed of our vertigoes is the same. We arrive at the same place at the same moment, which is not so with other people's thoughts. The language of nerves which we both use makes us brothers in writing.

The modern Christ said: I was born without a skin. I dreamed once that I stood naked in a garden and that it was carefully and neatly peeled, like a fruit. Not an inch of skin left on my body. It was all gently pulled off, all of it, and then I was told to walk, to live, to run. I walked slowly at first, and the garden was very soft, and I felt the softness of the garden so acutely, not on the surface of my body, but all through it, the soft warm air and the perfumes penetrated me like needles through every open bleeding pore. All the pores open and breathing the softness, the warm, and the smells. The whole body invaded, penetrated, responding, every tiny cell and pore active and breathing and trembling and enjoying. I shrieked with pain. I ran. And as I ran the wind lashed me, and then the voices of people like whips on me. Being touched! Do you know what it is to be touched by a human being!

He wiped his face with his handkerchief.

The paralytic sat still in the corner of the room.

You are fortunate, he said, you are fortunate to feel so much; I wish I could feel all that. You are at least alive to pain, whereas I... 
Então ele virou o rosto, mas antes de virar o rosto pude ver as veias incharem em sua testa, tamanho era o esforço que fazia, um esforço interno que nem sua língua, nem seu corpo, nem seus pensamentos obedeciam.

Se ao menos todos pudéssemos escapar desta casa do incesto, onde só amamos a nós mesmos no outro. Se ao menos pudesse salvá-los de si próprios, disse o Cristo moderno.

Mas nenhum de nós suportaria atravessar o túnel que nos levaria da casa para o mundo do outro lado dos muros, onde havia folhas nas árvores, onde a água corria à beira do caminho, onde havia luz e festa. Não éramos capazes de acreditar que o túnel se abriria para a luz do dia: temíamos que a escuridão nos aprisionasse outra vez; temíamos regressar ao mesmo lugar de onde havíamos partido, da escuridão e da noite. O túnel iria se estreitar e encolher enquanto estivéssemos atravessando, iria se fechar à nossa volta, tornando-se mais e mais apertado até nos sufocar. O túnel ficaria pesado e estreito e nos asfixiaria à medida que caminhássemos.

Todavia, sabíamos que para além da casa do incesto havia claridade e nenhum de nós ousava caminhar em sua direção.

Olhávamos agora para a dançarina no centro do quarto que dançava a dança da mulher sem braços. Ela dançava como se fosse surda e não acompanhasse o ritmo da música. Dançava como se não escutasse os sons das castanholas. Era uma dança isolada e separada da música e de nós e do quarto e da vida. As castanholas soavam como os passos de um fantasma.

Ela dançava, ria e suspirava e respirava como se estivesse sozinha. Ela dançava seus medos, fazendo pausas no meio de cada dança para escutar as críticas que não ouvíamos, ou para agradecer os aplausos que não eram nossos. Escutava uma música que não conseguíamos ouvir, movia-se por alucinações que não podíamos perceber.

Arrancaram meus braços, ela cantava. Fui castigada porque me prendia a tudo. Apertava fortemente. Prendia-me a todas as pessoas que amei. Prendia-me aos momentos felizes da vida; minhas mãos apertando cada hora do dia. Meus braços sempre rígidos e ávidos de abraçar. Queria abraçar e prender a luz, o vento, o sol, a noite, o mundo inteiro. Queria acariciar, curar, balançar, embalar, envolver, circundar. O esforço foi tanto e me agarrei tão fortemente que meus braços se desprenderam. Desprenderam-se de mim. Tudo me escapava. Estava condenada a não segurar. 
Then he turned his face away, and just before he turned away I saw the veins on his forehead swelling, swelling with the effort he made, the inner effort which neither his tongue nor his body, nor his thoughts would obey.

If only we could all escape from this house of incest,

Where we only love ourselves in the other, if only I could save you all from yourselves, said the modern Christ.

But none of us could bear to pass through the tunnel which led from the house into the world on the other side of the walls, where there were leaves on the trees, where water ran beside the paths, where there was daylight and joy. We could not believe that the tunnel would open on daylight: we feared to be trapped into darkness again; we feared to return whence we had come, from darkness and night. The tunnel would narrow and taper down as we walked; it would close around us, and close tighter and tighter around us and stifle us. It would grow heavy and narrow and suffocate us as we walked.

Yet we knew that beyond the house of incest there was daylight, and none of us could walk towards it.

We all looked now at the dancer who stood at the center of the room dancing the dance of the woman without arms. She danced as if she were deaf and could not follow the rhythm of the music. She danced as if she could not hear the sound of her castanets. Her dancing was isolated and separated from music and from us and from the room and from life. The castanets sounded like the steps of a ghost.

She danced, laughing and sighing and breathing all for herself. She danced her fears, stopping in the center of every dance to listen to reproaches that we could not hear, or bowing to applause that we did not make. She was listening to a music we could not hear, moved by hallucinations we could not see.

My arms were taken away from me, she sang. I was punished for clinging. I clung. I clutched all those I loved; I clutched at the lovely moments of life; my hands closed upon every full hour. My arms were always tight and craving to embrace. I wanted to embrace and hold the light, the wind, the sun, the night, the whole world. I wanted to caress, to heal, to rock, to lull, to surround, to encompass. And I strained and I held so much that they broke; they broke away from me. Everything eluded me then. I was condemned not to hold. 
Diante de seu corpo trêmulo e agitado, outra vez, estavam seus braços estendidos.

Observou as mãos fortemente cerradas e abriu-as lentamente, abriu-as completamente feito Cristo; abriu suas mãos num gesto de abandono e entrega; renunciou e perdoou ao abrir os braços e as mãos, deixando com que tudo fluísse para longe e para além de si mesma.

Não pude suportar a impermanência das coisas. Tudo fluindo, tudo passando, todo o movimento me sufocava de angústia.

E ela dançava; dançava com a música e com o ritmo dos círculos da terra; girava com a terra girando, como um disco, virando todas as faces para a luz e para a escuridão igualmente, dançando em direção à luz do dia. 
Trembling and shaking she stood looking at her arms now stretched before her again.

She looked at her hands tightly closed and opened them slowly, opened them completely like Christ; she opened them in a gesture of abandon and giving; she relinquished and forgave, opening her arms and her hands, permitting all things to flow away and beyond her.

I could not bear the passing of things. All flowing, all passing, all movement chocked me with anguish.

And she danced; she danced with the music and with the rhythm of earth's circles; she turned with the earth turning, like a disk, turning all faces to light and to darkness evenly, dancing towards daylight. 


\section{CONCLUSÃO}

Em A literatura em perigo (2009), Tzvetan Todorov realiza uma crítica ao modo como a literatura vem sendo ensinada nas escolas e universidades nas últimas décadas. Em sua visão, as teorias da literatura, cada vez mais, relegam o texto literário a um segundo plano e sua abordagem vem se reduzindo a uma técnica de classificações e categorizações. Os alunos, por sua vez, tornam-se especialistas e analistas literários. Todorov faz um apelo para que as bases de um ensino mais humanista sejam resgatadas, com o intuito de tirar os estudos literários da zona de perigo.

A literatura tem um impacto direto na sensibilidade humana, na nossa capacidade de ver, sentir, ouvir e tocar. É um dos instrumentos mais belos criados para conhecer e expandir os limites do humano - a grande obra inacabada que somos nós. De acordo com Todorov, aqueles que se dedicam aos estudos literários são, essencialmente, conhecedores mais profundos da natureza e da condição humana:

\footnotetext{
Sendo o objeto da literatura a própria condição humana, aquele que a lê e a compreende se tornará não um especialista em análise literária, mas um conhecedor do ser humano. Que melhor introdução à compreensão das paixões e dos comportamentos humanos do que uma imersão na obra dos grandes escritores que se dedicaram a essa tarefa há milênios? ${ }^{182}$
}

Ao abordar o universo ficcional criado por Anaïs Nin, ressaltei aspectos singulares de sua vida e obra. Enquanto escrevia a tese, busquei responder a seguinte pergunta: de que forma a obra de Nin contribuiu para expandir a nossa compreensão do que é ser humano? A primeira verdade com a qual me deparei é de que, em Nin, vida e arte compõem uma unidade. A vida de Nin foi um esforço contínuo de integração. As esferas intuitiva, racional, sexual, emocional e imaginativa deveriam, novamente, ser integradas à consciência para que o ser humano deixasse de ser apenas criatura e se tornasse criador. Vem daí a minha recusa em aprisionar a obra de Nin dentro de um corpus teórico demasiadamente rígido.

Dentre as inúmeras formas de abordagem, optei por dar ênfase à relação entre os diários e o poema A casa do incesto. Para dialogar com Nin, escolhi autores que

182 Todorov, A literatura em perigo, p. 92-93. 
compartilham do mesmo preceito de integração. Destaquei o aspecto imaginativo de sua escrita em detrimento de um foco apenas na dialética teórica. Meu grande desejo era de que minha pesquisa pudesse dar voz à sua sensibilidade imaginativa poética. Sem dúvida, este foi o grande desafio que enfrentei no processo de elaboração da tese.

Nin presenteia o leitor com doses generosas de sabedoria, das quais ressalto a ideia de que o processo criativo está relacionado a uma forma de desaprendizado. Esse seria o primeiro passo para o despertar da potência criadora. Outro aspecto, de grande impacto e importância em Nin, é o sentido que confere à palavra equilíbrio. Ao contrário do significado comum, equilíbrio na obra de Nin não é sinônimo de moderação, mas é um estado de espírito que reflete a capacidade do ser em abrigar internamente todos os extremos e contradições. A vida é um espectro de infinitas tonalidades de cores. Ser todas elas e, ao mesmo tempo, ser nenhuma: eis o gênio. 


\section{REFERÊNCIAS BIBLIOGRÁFICAS}

\section{Obras de Anaïs Nin}

NIN, Anaïs. The Dairy of Anaïs Nin, Volume One: (1931-1934). New York: The Swallow Press, and Harcourt, Brace \& World, 1966.

The Dairy of Anaïs Nin, Volume Two: (1934-1939). New York: The Swallow Press, and Harcourt, Brace \& World, 1967.

The Dairy of Anaïs Nin, Volume Three: (1939-1944). New York: The Swallow Press, and Harcourt, Brace \& World, 1969.

The Dairy of Anaïs Nin, Volume Four: (1944-1947). New York: The Swallow Press, and Harcourt, Brace \& World, 1971.

The Dairy of Anaïs Nin, Volume Five: (1947-1955). New York: The Swallow Press, and Harcourt, Brace \& World, 1974.

The Dairy of Anaïs Nin, Volume Six: (1955-1966). New York: The Swallow Press, and Harcourt, Brace \& World, 1976.

The Dairy of Anaïs Nin, Volume Seven: (1966-1974). New York: The Swallow Press, and Harcourt, Brace \& World, 1980.

Linotte: the Early Dairy of Anaïs Nin: (1914-1920). New York: Harcourt Brace Jovanovich, 1978.

The Early Dairy of Anaïs Nin, Volume Two: (1920-1923). New York: Harcourt Brace Jovanovich, 1982.

The Early Dairy of Anaïs Nin, Volume Three: (1923-1927). New York: Harcourt Brace Jovanovich, 1983.

The Early Dairy of Anaïs Nin, Volume Four: (1927-1931). New York: Harcourt Brace Jovanovich, 1985.

Henry and June: From the Unexpurgated Diary of Anaïs Nin. New York: Harcourt Brace Jovanovich, 1986.

Incest: From a Journal of Love. New York: Harcourt Brace Jovanovich, 1992.

Fire: From a Journal of Love. New York: Harcourt Brace Jovanovich, 1995.

Jovanovich, 1996.

Mirages: The Unexpurgated Diary of Anaïs Nin 1939-1947. Athens, Ohio: Swallow Press, 2013.

The House of Incest. Athens, Ohio: Swallow Press, 1994. 
. A casa do incesto. Trad. Isabel Hub Faria. Lisboa: Assírio \& Alvim, 1984.

. A casa do incesto e outras histórias. Trad. Angela Melim. Rio de Janeiro: Rosa dos Ventos, 1990.

. The Winter of Artifice. Denver: Swallow, revised edition, 1961.

. Under a Glass Bell.New York: Gemor Press, 1944.

Cities of the Interior. (Ladders to Fire, Children of the Albatross, The FourChambered Heart, A Spy in the House of Love, Seduction of the Minotaur). Denver: Swallow Press, 1974.

. Collages. Denver: Swallow Press, 1964.

. Delta of Venus: Erotica. New York: Harcourt Brace Jovanovich, 1977.

. Little Birds: Erotica. New York: Harcourt Brace Jovanovich, 1979.

. The White Blackbird and Other Writings. Santa Barbara: Capra Press, 1985.

. Waste of Timelessness and Other Early Stories. Ohio: Swallow Press, 1993.

. The Anaïs Nin Reader. (Ed. Philip K. Jason). Chicago: Swallow Press, 1961.

Press, 1995.

The Mystic of Sex: Uncollected Writings, 1931-1974. Santa Barbara: Capra

In Favor of the Sensitive Man, and Other Essays. New York: Harcourt Brace Jovanovich, 1976.

A Woman Speaks: The Lectures, Seminars and Interviews of Anaïs Nin. (Ed. Evelyn Hinz). Chicago: Swallow Press, 1975.

D.H. Lawrence: An Unprofessional Study. Chicago: Swallow Press, 1968.

The Novel of the Future. New York: Macmillan, 1968.

A Photographic Supplement to the Diary of Anaïs Nin. New York: Harcourt Brace Jovanovich, 1974.

DuBOW, Wendy M., (Ed.). Conversations with Anaïs Nin. Jackson: University Press of Mississipi, 1994.

STUHLMANN, Gunther, (Ed.). A Literate Passion: Letters of Anaïs Nin \& Henry Miller, 1932-1953. New York: Harcourt Brace Jovanovich, 1987.

MASON, Gregory H., (Ed.). Arrows of Longing: The Correspondence between Anaïs Nin and Felix Pollak. Athens, Ohio: Swallow Press, 1998. 


\section{Obras Críticas Sobre Anaïs Nin}

BAIR, Deirdre. Anaïs Nin: A Biography. New York: G. P. Putnam’s Sons, 1995.

BALAKIAN, Anna. "Anaïs Nin, the Poet". In: Nalbantian, Suzanne (Ed.). Anaïs Nin: Literary Perspectives. New York, St. Martin's Press, 1997, pp. 63 - 78.

DUXLER, Margot Beth. Seduction: A Portrait of Anaïs Nin. California: Edge Work Books, 2002.

EVANS, Oliver. Anaïs Nin. Edwardsville: Southern Illinois University Press, 1968.

FITCH, N. R. Anaïs: The Erotic Life of Anaïs Nin. New York: Little, Brown and Company, 1993.

FRANKLIN V, Benjamin. Anaïs Nin Character Dictionary and Index to Diary Excerpts. Troy: Sky Blue Press, 2009.

HERRON, Paul, (Ed.). A Café in Space: The Anaïs Nin Literary Journal, Volume 1 to 10. Troy, Michigan: Sky Blue Press.

HINZ, Evelyn. The Mirror and the Garden: Realism and Reality in the Writings of Anaïs Nin. New York: Harcourt Brace Jovanovich, 1973.

JASON, Philip K. The Critical Response to Anaïs Nin. Wesport: Greenwood Press, 1996.

JONG, Erica. The Devil at Large: Erica Jong on Henry Miller. New York: Turtle Bay, 1993.

KRAFT, Barbara. Anaïs Nin: The Last Days. San Jose: Pegasus Books, 2013.

MATHIEU, Bertrand. "On the Trail of Eurydice". In: STUHLMANN, Gunther (Ed.). Anaïs International Journal Volume 10, Los Angeles: Anaïs Nin Foundation, 1992, pp. 63-76.

MILLER, Henry.’Un Etre Etoilique”. In: JASON, Philip K (Ed.). The Critical Response to Anaïs Nin, London: Greenwood, 1996, pp. 147- 154.

"About the Mona Pages". In: STUHLMANN, Gunther (Ed.). Anaïs International

Journal Volume 6, Los Angeles: Anaïs Nin Foundation, 1988, pp. 93-103.

MILLETT, Kate. “Anaïs: A mother to us all”. In: STUHLMANN, Gunther (Ed.). Anaïs International Journal Volume 2, Los Angeles: Anaïs Nin Foundation, 1991, pp. 3-8.

NALBANTIAN, Suzanne. Anaïs Nin: Literary Perspectives. New York: St. Martin’s Press, 1997.

Aesthetic Autobiography: From Life to Art in Marcel Proust, James Joyce, Virginia Woolf and Anaïs Nin. New York: St. Martin's press, 1994.

. Memory in Literature: From Rousseau to Neuroscience. New York: Palgrave Macmillan, 2003. 
"Into the House of Myth". In: STUHLMANN, Gunther (Ed.). Anaïs International Journal Volume 11, Los Angeles: Anaïs Nin Foundation, 1993, pp. 1215 .

OWEN, Jean. "Uncanny Echoes: Anaïs Nin Narrative of Incest". In: HERRON, Paul (Ed). A Café in Space: The Anaïs Nin Literary Journal Volume 11, Santo Antonio: Sky Blue Press 2014, pp. $41-43$.

RANK, Otto. "On the Early Diary: A Preface". In: STUHLMANN, Gunther (Ed.). Anaïs International Journal Volume 2, Los Angeles: Anaïs Nin Foundation, 1984, pp. $20-23$.

RICHARD-ALLERDYCE, Diane. Anaïs Nin and the Remaking of Self: Gender, Modernism and Narrative Identity. DeKalb: Northern Illinois University Press, 1998.

SPENCER, Sharon. Collage of Dreams: The Writings of Anaïs Nin. Chicago: The Swallow Press, 1977.

Space, Time and Structure in the Modern Novel. New York: New York University Press, 1971.

STUHLMANN, Gunther, (Ed.). Anaïs: An International Journal, Volume 1 to 19. Los Angeles: Anaïs Nin Foundation.

TOOKEY, Helen. Anaïs Nin, Fictionality and Femininity: Playing a Thousand Roles. Oxford: Clarendon Press, 2003. 


\section{Referencial Teórico e Outros}

ANDREAS-SALOMÉ, Lou. Looking back: The Memoirs of Lou Andreas-Salomé. Ernest Pfeiffer (Ed.); Breon Mitchell (Trad.). New York: Paragon House, 1991.

ARTAUD, Antonin. O teatro e seu duplo. Trad. Teixeira Coelho. São Paulo: Martins Fontes, 2006.

. Linguagem e vida. Trad. J. Guinsburg, Sílvia Fernandes, Regina Correa Rocha e Maria Lúcia Pereira. São Paulo: Perspectiva, 2011.

BACHELARD, Gaston. A poética do devaneio. Trad. Antonio de Pádua Danesi. São Paulo: Martins Fontes, 2009.

La intuición del instante. Trad. Jorge Ferreiro. México: Fondo de Cultura Económica, 1999.

A terra e os devaneios do repouso: ensaio sobre as imagens da intimidade. Trad. Paulo Neves. São Paulo: Martins Fontes, 1990.

A psicanálise do fogo. Trad. Paulo Neves. São Paulo: Martins Fontes, 1990.

Fontes, 1990.

A poética do espaço. Trad. Antonio de Pádua Danesi. São Paulo: Martins

. A água e os sonhos: ensaio sobre a imaginação da matéria. Trad. Antonio de Pádua Danesi. São Paulo: Martins Fontes, 1998.

2009.

O ar e os sonhos. Trad. Antonio de Pádua Danesi. São Paulo: Martins Fontes, A dialética da duração. Trad. Marcelo Coelho. São Paulo: Editora Ática, 1994.

BALAKIAN, Anna. Literary Origins of Surrealism. New York: New York University Press, 1966.

1986.

. Surrealism: The Road to the Absolute. Chicago: Chicago University Press,

BARNES, Djuna. Nightwood. London: Faber and Faber, 2007.

BATAILLE, George. O erotismo. Trad. Fernando Scheibe. Belo Horizonte: Autêntica Editora, 2014.

BAUDELAIRE, Charles. As flores do mal. Trad. Ivan Junqueira. Rio de Janeiro: Nova Fronteira, 2006.

2009.

Meu coração desnudado. Trad. Tomaz Tadeu. Belo Horizonte: Autêntica,

BENJAMIN, Walter. Obras escolhidas I. Magia e técnica, arte e política. Ensaios sobre literatura e história da cultura. Trad. Sérgio Paulo Rouanet. São Paulo: Editora Brasiliense, 1996. 
A Tarefa do Tradutor. Quatro traduções para o português. Organização de Lúcia Castelo Branco. Traduções. Fernando Camacho, Karlheinz Barck e outros, Susana Kampff Lages, João Barreto. Belo horizonte: Fale/ UFMG, 2008.

BLAKE, William. O matrimônio do céu e do inferno e o livro de Thel. Trad. José Antônio Arantes. São Paulo: Iluminuras, 2007.

BLANCH, Lesley. The Wilder Shores of Love. New York: Simon \& Shuster, 2010.

BLOOM, Harold. Presságios do milênio: anjos, sonhos e imortalidade. Trad. Marcos Santarrita. Rio de Janeiro: Objetiva, 1996.

Genius: A Mosaic of One Hundred Exemplary Creative Minds. New York: Warner Books, 2002.

BRADLEY, Fiona. Surrealismo. Trad. Sérgio Alcides. São Paulo: Cosac Naify, 2001.

BRETON, André. Nadja. Trad. Ivo Barroso.São Paulo: Cosac Naify, 2012.

What is Surrealism? Selected Writings. (Ed. Franklin Rosemont). New York: Pathfinder, 1978. . Manifestos do Surrealismo. Trad. Jorge Forbes. São Paulo: Brasiliense, 1985. O amor louco. Trad. Luiza Neto Jorge. Lisboa: Estampa, 1971.

CAMPOS, Haroldo. Metalinguagem e outras metas. São Paulo: Perspectiva, 1992.

CESAR, Ana Cristina. Crítica e tradução. São Paulo: Editora Ática, 1999.

CIORAN, Emil. The Trouble with Being Born. Trad. Richard Howard. New York: Arcade, 2012. 1990.

. A Short History of Decay. Trad. Richard Howard. London: Quartet Book,

CORBIN, Henry. Alone with the Alone: Creative Imagination in the Sufism of Ibn Arabi. Princenton: Princenton University Press, 1997.

DERRIDA, Jacques. Torres de Babel. Trad. Junia Barreto. Belo Horizonte: Editora UFMG, 2002.

DUNCAN, Robert. The H.D. Book. Berkeley, Los Angeles, London: University of California Press, 2011.

ELIADE, Mircea. $O$ xamanismo e as técnicas arcaicas do êxtase. Trad. Beatriz Perrone-Moisés e Ivone Castilho Benedetti. São Paulo: Martins Fontes, 2002.

FAURE, Élie. The Dance over Fire and Water. Trad. John Gould Fletcher. New York: Harper and Brothers Publisher, 1926.

FERREIRA, Luzilá Gonçalves. "Lou Andreas-Salomé: a Paixão Viva". In: Adauto Novaes (org.). Os sentidos da paixão. São Paulo: Companhia das Letras, 2009, PP. 410427.

FOWLIE, Wallace. Age of Surrealism. Bloomington: Indiana University Press, 1960. 
GRAVES, Robert. The White Goddess: A Historical Grammar of Poetic Myth. New York: Farrar, Straus and Girox, 1999.

GUINSBURG, J. \& LEIRNER, Sheila (org.). O Surrealismo. São Paulo: Perspectiva, 2008.

IANELLI, Mariana. Almádena. São Paulo: Iluminuras, 2007.

JUNG, C. G. O eи e o inconsciente. Trad. Dora Ferreira da silva. Petrópolis: Editora Vozes, 1987.

Psicologia e Alquimia. Trad. Maria Luiza Appy, Margaret Makray \& Dora Ferreira da Silva. Petrópolis: Editora Vozes, 2011.

O espírito na arte e na ciência. Trad. Maria de Moraes Barros. Petropolis: Editora Vozes, 2008.

Dreams. New York: MJF Books, 1974.

KUNDERA, Milan. A arte do romance. Trad. Teresa Bulhões Carvalho da Fonseca. São Paulo: Companhia das Letras, 2009.

KANDINSKY, Wassily. Concerning the Spiritual in Art. Trad. M. T. H. Daddler. New York: George Wittenborn, 1947.

LAGES, Susana Kampff. Walter Benjamin: tradução e melancolia. São Paulo: Editora da Universidade de São Paulo, 2007.

LAUTRÉAMONT, Comte de. Cantos de Maldoror. Trad. Cláudio Willer. São Paulo: Vertente, 1970.

LAWRENCE, David Herbert. Erotic Works of D. H. Lawrence. Claire Boss \& Christopher Busa (Ed.). New York: Avenel Books, 1989.

1994.

The Complete Poems of D. H. Lawrence. London: Wordsworth Poetry Library,

LEMINSKI, Paulo. Anseios crípticos 2. Curitiba: Criar, 2001.

MABILLE, Pierre. Mirror of the Marvelous: The Classic Surrealist Work on Myth. Trad. Jody Gladding. Rochester: Inner Traditions, 1998.

MICHAUX, Henri. Miserable Miracle. Trad. Louise Varèse \& Anna Moschovakis. New York: New York Review Books, 2002.

MILLER, Henry. The Time of the Assassins: A Study Of Rimbaud. New York: New Directions, 1962. Press, 1980.

The World of Lawrence: A Passionate Appreciation. Santa Barbara: Capra Henry Miller on Writing: Selected by Thomas H. Moore from the Published and Unpublished Works of Henry Miller. New York: New Direction, 1964. 
NIETZSCHE, Friedrich. Humano, demasiado humano. Trad. Paulo César de Souza. São Paulo: Companhia das Letras, 2005.

2005. Assim falou Zaratustra. Trad. Heloisa da Graça Burati. São Paulo: Rideel,

NOVAES, Adauto (org.). Os sentidos da paixão. São Paulo: Compahia das Letras, 2009.

PAGLIA, Camille. Sexual Personae: Art and Decadence from Nefertiti to Emily Dickinson. New York: Vintage Books, 1995.

PAZ, Octavio. The Double Flame: Love and Eroticism. Trad. Helen Lane. Orlando: Harcourt Brace \& Company, 1995. 1996. Signos em rotação. Trad. Sebastião U. Leite. São Paulo: Editora Perspectiva, Naify, 2013.

Os filhos do barro. Trad. Ari Roitman \& Paulina Wacht. São Paulo: Cosac 2012. . O arco e a lira. Trad. Ari Roitman \& Paulina Wacht. São Paulo: Cosac Naify,

PESSOA, Fernando. Fernando Pessoa: obra poética, volume único. Rio de Janeiro: Nova Aguilar, 2006.

PFEIFFER, Ernst (Ed.). Sigmund Freud and Lou Andreas-Salomé Letters. Trad. William and Elaine Robson-Scott. New York: Harcourt Brace Jovanovich, 1972.

RAINE, Kathleen. "Science and Imagination in William Blake". In: Temenos: A Review Devoted to the Arts of the Imagination, volume 1. London: September Press, 1981, pp. $37-58$.

RANK, Otto. Truth and Reality. Trad. Jessie Taft. New York/London: W.W. Norton \& Company, 1978.

Art and Artist: Creative Urge and Personality Development. Trad. Charles Francis Atkinson. New York/London: W.W. Norton \& Company, 1989.

The Double: A Psychoanalytic Study. Trad. Harry Tucker, Jr. Chapel Hill: The University of North Carolina Press, 1971.

The Incest Theme in Literature \& Legend: Fundamentals of a Psychology of Literary Creation. Trad. Gregory C. Richter. Baltimore: The Johns Hopkins University Press, 1992.

RIMBAUD, Arthur. I Promise to be Good: The letters of Arthur Rimbaud. Trad. Wyatt Mason. New York: The Modern Library, 2004.

Arthur Rimbaud: poesia completa. Trad. Ivo Barroso. Rio de Janeiro: Topbooks, 1994.

2008.

Uma temporada no inferno. Trad. Paulo Hecker Filho. Porto Alegre: L\& PM, 
SCHÜLER, Donaldo. Eros: dialética e retórica. São Paulo: Edusp, 1992.

TODOROV, Tzvetan. A literatura em perigo. Trad. Caio Meira. Rio de Janeiro: Difel, 2014.

WILLER, Claudio. Um obscuro encanto: gnose, gnosticismo e poesia moderna. Rio de Janeiro: Civilização Brasileira, 2010.

Manifestos 1964 - 2010. Rio de Janeiro: Beco do Azougue, 2013.

"Magia, Poesia e Realidade: o Acaso Objetivo em André Breton". In: GUINSBURG, LEINER (org.). O Surrealismo. São Paulo: Perspectiva, 2008, pp. 281 322.

"Surrealismo: Poesia e Poética". In: GUINSBURG, LEINER (org.). $O$ Surrealismo. São Paulo: Perspectiva, 2008, pp. 323 - 352. 


\section{Internet}

HUGO, Ian. The Bells of Atlantis. Curta experimental em que a própria Anaïs Nin recita trechos de House of Incest. Disponível em: https://www.youtube.com/watch?v=HE$7 q$ Eftad8

SNYDER, Robert. Anaïs Nin Observed: Portrait of a Woman as Artist. Trecho de um documentário sobre Anaïs Nin. Disponível em: https://www.youtube.com/watch?v=zP1RuXw6ubo

CEZAR, Pedro. Só dez por cento é mentira. Documentário sobre Manoel de Barros. Disponível em: https://www.youtube.com/watch?v=QZLC8wNVtfs 